\title{
The influence of beaver impoundments on vegetative composition, and modeling habitat suitability as a tool for wildlife management and conservation
}

Jerry LeAnne Bonner

West Virginia University

Follow this and additional works at: https://researchrepository.wvu.edu/etd

\section{Recommended Citation}

Bonner, Jerry LeAnne, "The influence of beaver impoundments on vegetative composition, and modeling habitat suitability as a tool for wildlife management and conservation" (2005). Graduate Theses, Dissertations, and Problem Reports. 2299.

https://researchrepository.wvu.edu/etd/2299

This Thesis is protected by copyright and/or related rights. It has been brought to you by the The Research Repository @ WVU with permission from the rights-holder(s). You are free to use this Thesis in any way that is permitted by the copyright and related rights legislation that applies to your use. For other uses you must obtain permission from the rights-holder(s) directly, unless additional rights are indicated by a Creative Commons license in the record and/ or on the work itself. This Thesis has been accepted for inclusion in WVU Graduate Theses, Dissertations, and Problem Reports collection by an authorized administrator of The Research Repository @ WVU. For more information, please contact researchrepository@mail.wvu.edu. 


\title{
THE INFLUENCE OF BEAVER IMPOUNDMENTS ON VEGETATIVE COMPOSITION, AND MODELING HABITAT SUITABILITY AS A TOOL FOR WILDLIFE MANAGEMENT AND CONSERVATION.
}

\author{
Jerri LeAnne Bonner
}

Thesis submitted to the Davis College of Agriculture, Forestry, and Consumer Sciences

at West Virginia University in partial fulfillment of the requirements for the degree of

\author{
Master of Science \\ In \\ Wildlife and Fisheries Resource Management
}

James T. Anderson, Ph.D., Major Advisor

William N. Grafton, M.S.

John W. Edwards, Ph.D.

Morgantown, West Virginia

2005

Keywords: Beaver, Castor canadensis, Geographic Information Systems, Habitat model, Pond, Rare Plant Species, Vegetation, Wetland 


\section{Abstract \\ The influence of beaver impoundments on vegetative composition, and modeling habitat suitability as a tool for wildlife management and conservation.}

\section{Jerri LeAnne Bonner}

Beavers (Castor canadensis) can have dramatic effects on vegetative communities through impounding streams and wetlands. These alterations may influence rare plant species where beaver create ponds. We found that the youngest and oldest beaver ponds in Canaan Valley, West Virginia, USA had similar species richness. Rare plant species occurred most in oldest ponds, although no significant differences were detected. Species composition around ponds was found to be different between areas influenced by ponds versus those not affected, creating more obligate wetland communities when influenced by beaver. This information should be incorporated into management decisions when rare plant species conservation is a priority. Our validated geographic information systems model can be used in planning management activities. We believe limited and regulated trapping can aid in beaver reduction without negatively affecting rare plants, although a beaver population should be conserved in the areas of the oldest ponds to maintain rare plant species. 


\section{ACKNOWLEDGMENTS}

I thank the following people for their help during vegetation sampling and beaver trapping conducted during this project: Kelley L. Flaherty, Cara C. Hoar, Jason Alexander, Joseph D. Osbourne, Chris D. Horn, Jason P. Love, Jennifer A. Edalgo, and Jennifer E. Love. I extend a special thanks to Dr. George E. Seidel, for statistical assistance, and Dr. Michael Strager, for assistance with geographic information systems. Special thanks also is extended to my graduate committee. In particular, thanks to my advisor James T. Anderson, for support and for providing this opportunity. Also my deepest gratitude to William N. Grafton and Dr. James S. Rentch, for field support and constant advice. I also thank the Canaan Valley Institute, the Cooperative State Research, Education, and Extension Service, the Regional Research Institute of West Virginia University, and the West Virginia University Division of Forestry for funding and logistical support of this project. I thank Canaan Valley National Wildlife Refuge for access to our study sites and thank refuge biologist Ken Sturm for his constant support of this research.

Finally, but very importantly, I thank my family and friends for all the much needed support they provided during this adventure. Putting up with me is probably a constant pain, and I appreciate it more than you all know. 
TABLE OF CONTENTS

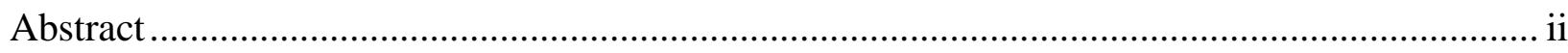

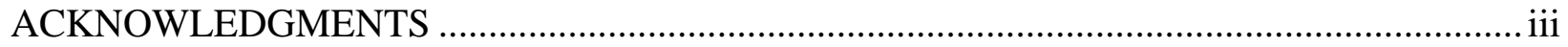

TABLE OF CONTENTS.............................................................................................. iv

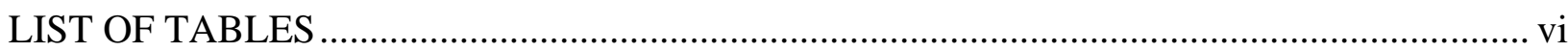

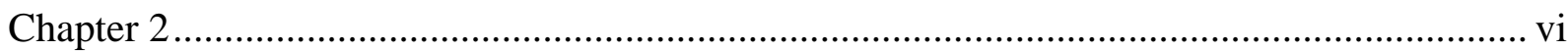

Chapter 3 .................................................................................................................... vi

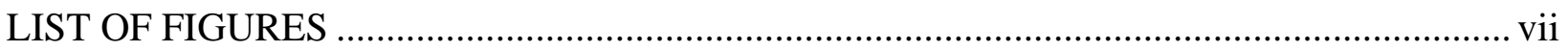

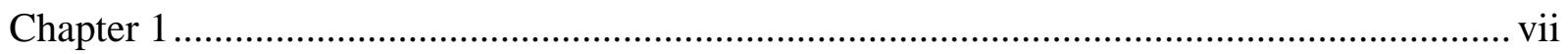

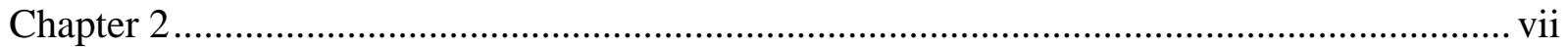

Chapter 3 ................................................................................................................... vii

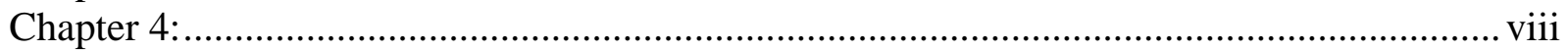

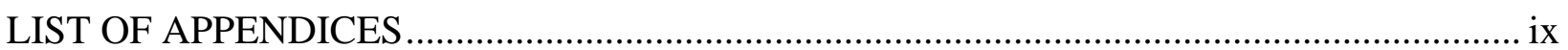

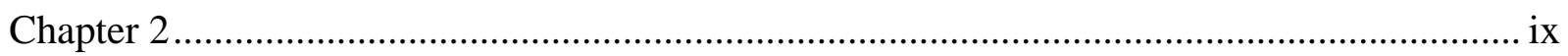

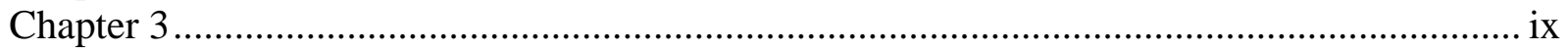

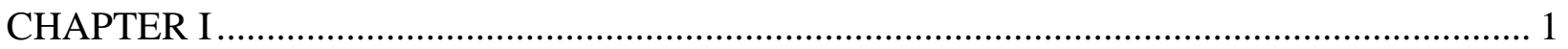

INTRODUCTION TO BEAVER, HABITAT MODELING, AND CANAAN VALLEY............ 1

INTRODUCTION AND JUSTIFICATION..................................................................... 1

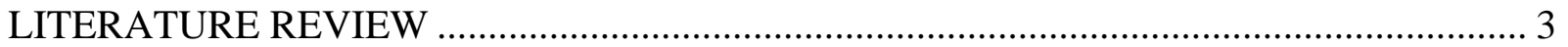

Beaver Natural History ……………………………..................................................... 3

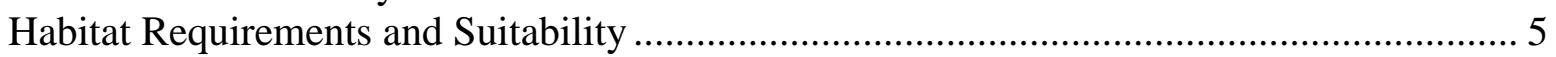

Modeling and Geographic Information Systems ............................................................... 8

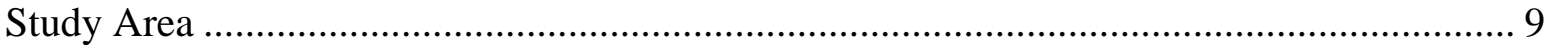

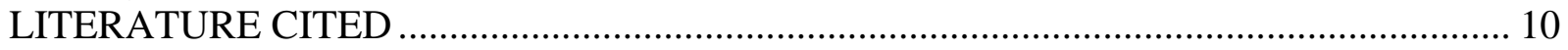

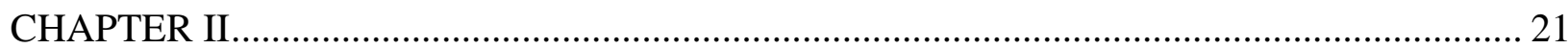

VEGETATIVE COMPOSITION AND COMMUNITY STRUCTURE ASSOCIATED WITH BEAVER PONDS IN CANAAN VALLEY, WEST VIRGINIA, USA........................................ 21

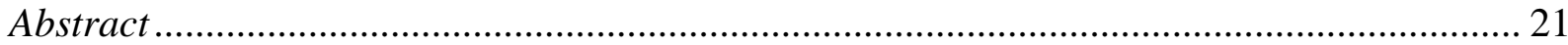

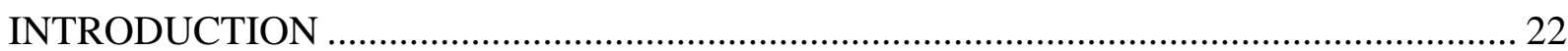

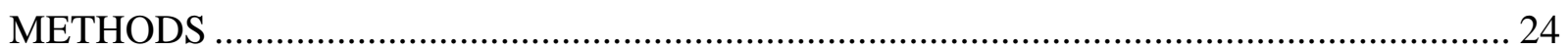

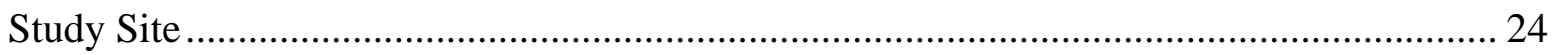

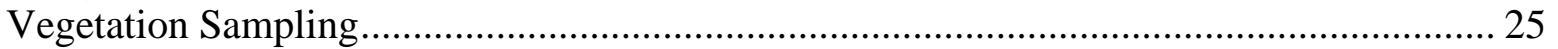

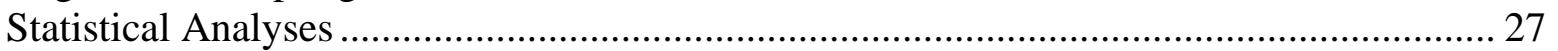

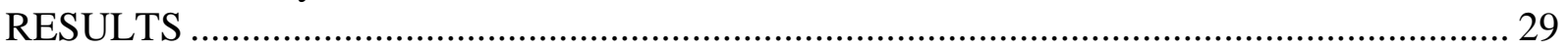

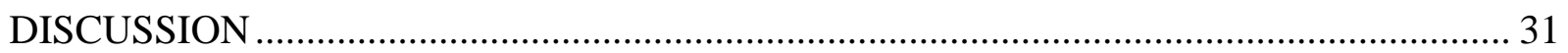

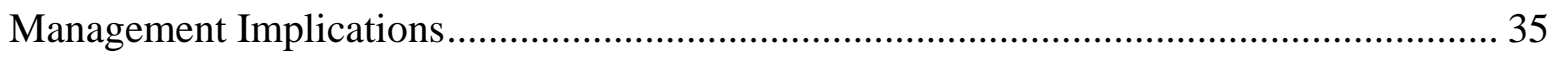

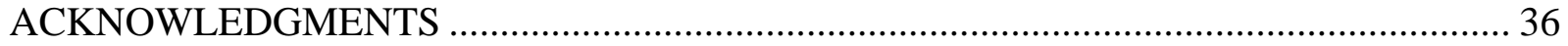

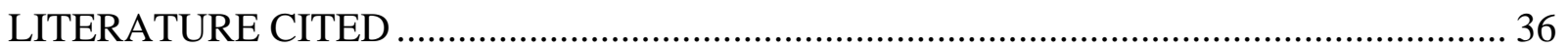

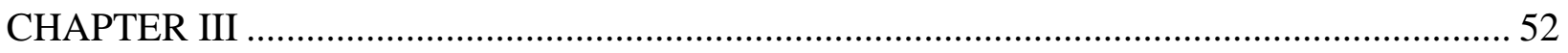




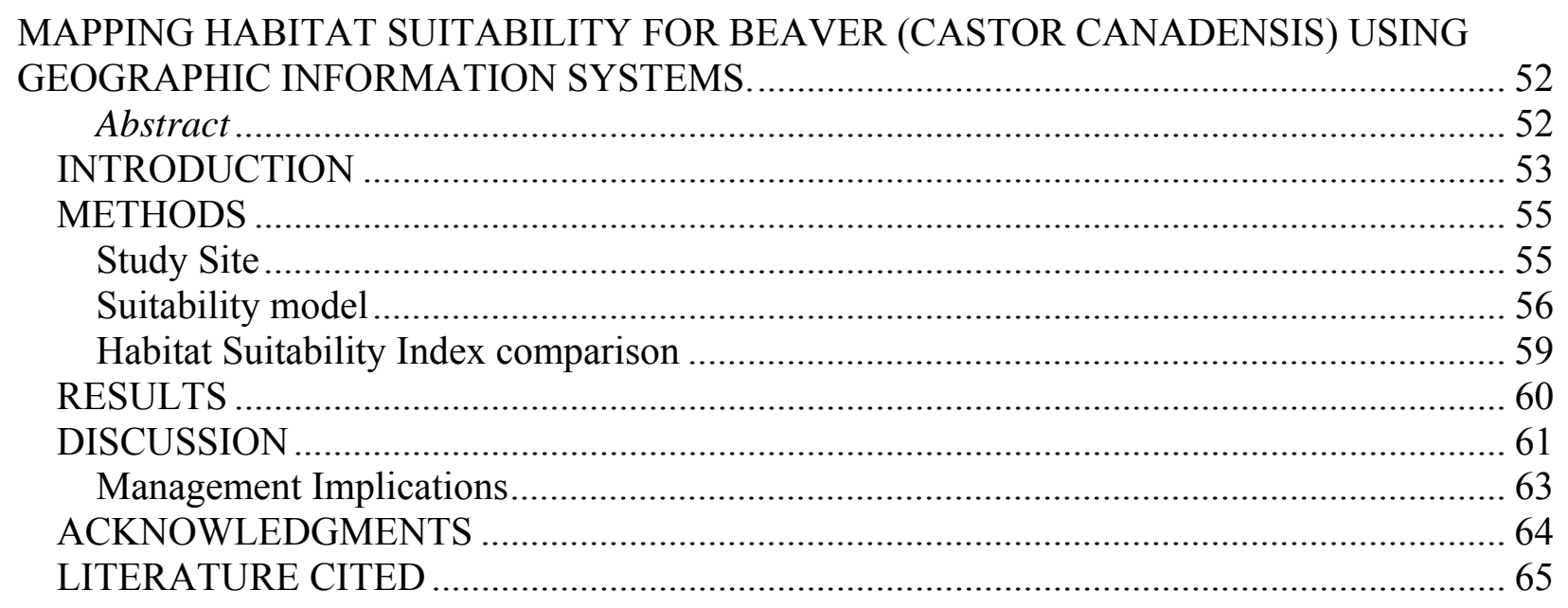

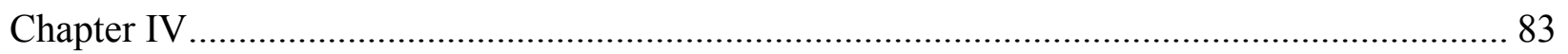

Conclusions and management implications for vegetation associated with beaver ponds and

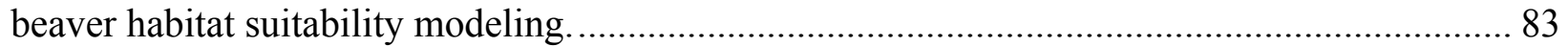

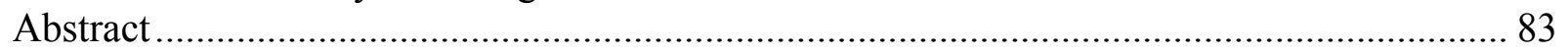

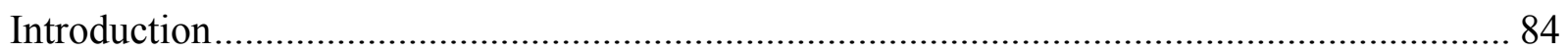

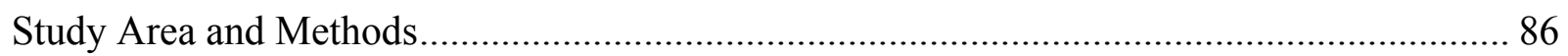

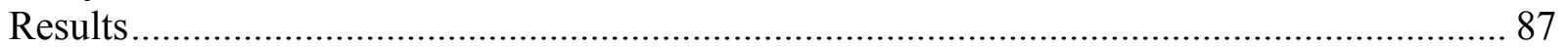

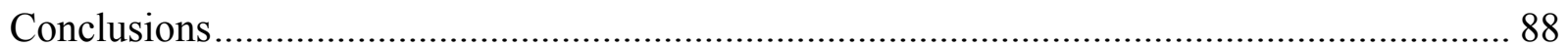

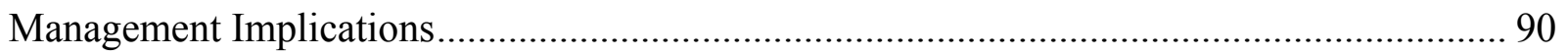

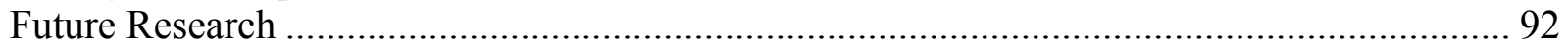

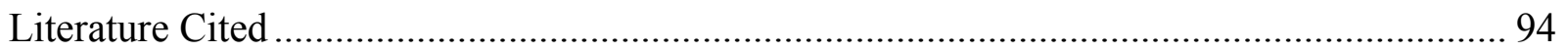




\section{LIST OF TABLES}

Chapter 2: Vegetative composition and community structure associated with beaver ponds in Canaan Valley, West Virginia, USA.

Table 1. Rare plant species observed during transect and walk-around surveys of beaver ponds in Canaan Valley, West Virginia, USA, 2004-2005. Nomenclature follows Kartesz (1999).... 41

Table 2. Most commonly occurring plant species around beaver ponds in Canaan Valley, West Virginia, USA based on the number of ponds at which each species occurred. Nomenclature

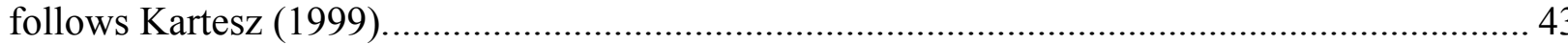

Table 3. Multiple analyses of vegetation data from Canaan Valley, West Virginia, USA, 20042005. Index represents the dependent variable being tested. Groups were tested between locations in relation to beaver ponds (plot location) and for differences among age (pond age) ${ }^{\mathrm{a}}$. All numbers shown are untransformed data.

Table 4. Results of the Multiple Response Permutation Procedure (MRPP) testing the null hypothesis of no significant difference in herbaceous or shrub community composition between sites based on size and age classes and location in relation to beaver ponds in Canaan Valley, West Virginia, USA.

Table 5 Correlations of herbaceous species and cover types associated with two primary axes in non-metric multi-dimensional scaling (NMS) ordination for beaver ponds in Canaan Valley, West Virginia, USA. Nomenclature follows Kartesz (1999).

\section{Chapter 3: Mapping habitat suitability for beaver (Castor canadensis) using geographic information systems.}

Table 1. Layers used in the geographic information system (GIS) model to characterize beaver habitat suitability. Values for each category range from 0 (unsuitable) to 9 (highly suitable). Weight represents importance for suitable beaver habitat, highest value represent highest importance in model. Weights and values were derived from relevant literature, including Brooks (1957), Allen (1983), Barnes and Mallik (1997), and Suzuki and McComb (1998).....69

Table 2. Values are given for each model at each of 26 survey locations in Canaan Valley, WV, USA in summer 2005. Habitat suitability index (HSI) value indicates calculated value using formulas described by Allen (1983). Model point values are the geographic information systems (GIS) model values for each location. Buffered GIS values are mean value of the area within a $200 \mathrm{~m}$ radius from each point. Latitude and longitude are calculated in North American Datum 1983. .70

Table 3. Rare plant species locations in Canaan Valley, West Virginia, USA were overlaid on a geographic information systems (GIS) habitat suitability model. Locations indicate the number of occurrences of each rare plant species. Model score represents the mean value of beaver habitat for each plant species. Scores range from 0 (unsuitable for beaver) to 9 (highly suitable beaver habitat). 


\section{LIST OF FIGURES}

Chapter 1: Introduction to beaver, habitat modeling, and Canaan Valley.

Figure 1. Arial photography showing the Canaan Valley, West Virginia, USA area. Yellow line indicates boundary of Canaan Valley................................................. 16

Figure 2. A beaver pond complex created on a small tributary of the Blackwater River in Canaan Valley, West Virginia, USA 17

Figure 3. Oceanurus (Zigadenus leimanthoides) is one of over 50 rare plant species found in several locations throughout Canaan Valley, West Virginia, USA.........................18

Figure 4. Some rare plant communities occur around or nearby beaver impoundments, such as Juncus spp. communities present in the foreground and red spruce (Picea rubens) in the distance.

Figure 5. Canaan Valley National Wildlife Refuge (CVNWR) boundaries are shown in black over the gray area of Canaan Valley. Inset shows Canaan Valley located in Tucker County, WV, USA. .20

Chapter 2: Vegetative composition and community structure associated with beaver ponds in Canaan Valley, West Virginia, USA.

Figure 1. Location of beaver ponds surveyed for vegetation in 2004 (white stars) and 2005 (black diamonds) in Canaan Valley (Tucker County), West Virginia, USA.

Figure 2. Non-metric multi-dimensional scaling (NMS) ordination graph showing the two most explanatory axes of ponds surveyed in Canaan Valley, West Virginia, USA in 2004-2005. Black squares (inside) indicate communities inside the influence of the impoundment. Hollow diamonds (outside) represent communities outside of this influence. Community data includes herbaceous species and cover variables. .51

\section{Chapter 3: Mapping habitat suitability for beaver (Castor canadensis) using geographic information systems.}

Figure 1. Canaan Valley National Wildlife Refuge (CVNWR) boundaries are shown in black over the gray area of Canaan Valley. Inset shows Canaan Valley located in Tucker County, WV, USA. 74

Figure 2. Available woody resources for beaver in Canaan Valley, WV, USA are shown. Polygons display suitability rankings based on described preferences of certain tree types: no defined tree type (0), conifers (1), hardwoods (5), and quaking aspen (9)

Figure 3. Suitable habitat based on proximity to water in Canaan Valley, WV, USA is displayed. Highest suitability is located in areas of water cover and land in close proximity to water (9) with suitability decreasing as distance to water increases $(5=$ moderately suitable, $1=$ least suitable, 0 $=$ unsuitable) 
Figure 4. Stream gradient values within Canaan Valley, WV, USA. Streams were not present in unsuitable areas (0). Highly suitable stream gradients (9) are low gradient; suitability decreases with increased gradient $(7=$ more suitable, $5=$ moderately suitable, $3=$ less suitable, $1=$ least

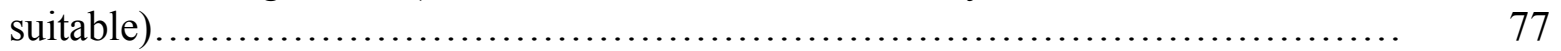

Figure 5. Overall beaver habitat suitability for Canaan Valley, WV, USA was determined by combining stream gradient, vegetation, and distance using a weighted model. Highest suitability is found in areas of low gradients, close proximity to water, and highly preferred food species. A color gradient from black to white shows changes in suitability from most suitable to unsuitable...

Figure 6. Rare plant species occurring along Glade Run in Canaan Valley, West Virginia, USA. Rare plant species are shown in relation to geographic information systems (GIS) beaver habitat suitability model. Model values are represented by a gradient from white (lowest suitable

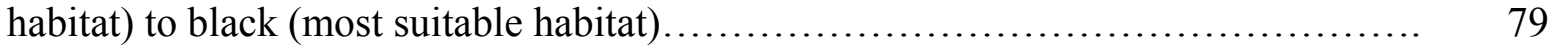

Figure 7. Transect surveys of vegetative characteristics were conducted at 26 random locations throughout Canaan Valley National Wildlife Refuge in Canaan Valley, West Virginia, USA. Grey areas indicate refuge property. Black stars represent survey locations. Black outline shows the ridges surrounding the valley

Figure 8. Results of validation of geographic information systems (GIS) model by comparison of active beaver colony sites and randomly selected locations in Canaan Valley, West Virginia, USA. Type is depicted on the x-axis. Mean GIS model score is shown on y-axis. Bars represent standard error.

Figure 9. Mean geographic information systems (GIS) model values and habitat suitability index (HSI) values derived from vegetation surveys. Values of HSI are less than GIS values but similar to buffered GIS values. Model type is shown on x-axis: GIS is a single location value; buffered GIS is the mean value of a $200 \mathrm{~m}$ buffer around a point; HSI is the values from survey data. Mean values are shown on y-axis. Bars indicate standard error.

\section{Chapter 4: Conclusions and management implications for vegetation associated with beaver ponds and beaver habitat suitability modeling.}

Figure 1. The Canaan Valley area in Tucker County, West Virginia, USA is shown in gray. Black line indicates the boundary of Canaan Valley National Wildlife Refuge. 


\section{LIST OF APPENDICES}

Chapter 2: Vegetative composition and community structure associated with beaver ponds in Canaan Valley, West Virginia, USA.

Appendix 1. Rare wetland species known to occur in Canaan Valley, West Virginia, USA. Global indicates global status of a species; state indicates status of species in West Virginia. WIS represents wetland indicator status (U.S. Fish and Wildlife 1996). Nomenclature follows Kartesz (1999)

Appendix 2. Herbaceous species occurring around beaver ponds in Canaan Valley, West Virginia, USA based on mean percent cover. Of four cover types and 153 species observed during transects, only 26 had a mean occurrence of $>1 \%$ cover in surveyed plots. Cover types are shown in bold. Maximum cover (Max) is a percentage. Ponds indicates the number of ponds at which each species occurred. Species names standardized according to Kartesz (1999)...... 101

Appendix 3. Shrub analysis for each pond based on average shrub cover percentage observed during surveys of beaver ponds in Canaan Valley, West Virginia, USA. Maximum cover is a percentage. Ponds indicates number of ponds at which each species was observed. Species names standardized according to Kartesz (1999).

Appendix 4. Vegetation observed during walk around surveys of beaver ponds in Canaan Valley, WV, USA. Additional species includes all species not detected during transects but observed during the random walk-around surveys. All species names were standardized using Kartesz (1999). Observations indicates number of ponds at which each species was observed.

Chapter 3: Mapping habitat suitability for beaver (Castor canadensis) using geographic information systems.

Appendix 5. Locations of rare plant species in Canaan Valley, West Virginia, USA.

Coordinates (X, Y) are displayed in North American Datum 1927. Global indicates global status of a species; state indicates status of species in West Virginia. Species names are standardized

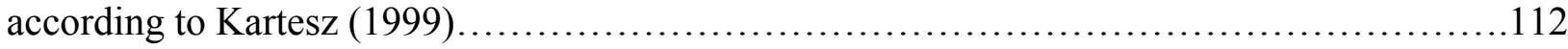




\title{
CHAPTER I
}

\section{INTRODUCTION TO BEAVER, HABITAT MODELING, AND CANAAN VALLEY.}

\author{
Jerri L. Bonner and James T. Anderson \\ West Virginia University \\ Division of Forestry, Wildlife and Fisheries Resources Program \\ Morgantown, WV 26506 \\ Email: autralfamadorian@hotmail.com
}

\section{INTRODUCTION AND JUSTIFICATION}

The Canaan Valley of West Virginia is a high elevation, canoe-shaped valley (Fig. 1) that was historically home to large stands of red spruce (Picea rubens) and other species considered rare for the region. In the late 1800 s and early 1900 s, forests were harvested for timber; the lack of the spruce canopy led to a drier habitat, and fires devastated the valley. Although the soils and vegetation of the valley have recovered somewhat, the forests are now primarily deciduous hardwoods, with a small percentage of spruce surviving. In the 1930s, beaver (Castor canadensis) were re-introduced to the valley (Swank 1949). The dam-building activities of these semi-aquatic mammals alter forest succession by flooding areas (Barnes and Dibble 1988, Naiman et al. 1988), leading to changes in sediment retention, invertebrate communities, vegetative composition, and stream morphology (Naiman et al. 1986, Wright et al. 2002). In Canaan Valley, this flooding has contributed to a 40 percent reduction in developing coniferous forests (Fortney and Rentch 2003).

Herbivory by beavers also can have a dramatic effect on successional trends along streams (Barnes and Dibble 1988). Trembling aspen (Populus tremuloides) is rare in the valley, but it also is the preferred food type for beavers in areas where available, including nearby areas of Pennsylvania (Brenner 1962). In some areas the preferred food types in foraging areas can be 
effectively clear-cut (Naiman et al. 1988). The end result of this herbivory can be an increase in density of undesirable foods and a decrease of the preferred choices in future generations (Barnes and Dibble 1988).

Fortney and Rentch (2003) named beaver activities as one potential factor in the reduction of some rare plant communities in the valley. Although beaver would have influenced the valley before their extirpation from the area, the current ecological system in the valley is dramatically different from pre-logging conditions (Brooks 1957). Historically beaver activities were a natural influence on a primarily unaltered landscape, but today they are a potential hindrance to typical successional patterns. Naiman et al. (1988) indicate the potential for beaverinduced community types, such as fens and wet meadows, to be enduring stages of succession instead of temporary patches. Thus, the current sub-climax community could be long-term if beaver flooding and herbivory suppress the growth of the valley's climax plant communities. We hypothesized that beaver activities do adversely affect successional patterns and limit growth of rare plant communities in Canaan Valley.

The impacts on rare plant communities need to be evaluated, considering that in many habitats beaver activities may lead to local declines of certain species (Mitchell and Niering 1993). However, on a landscape level, beaver activity can possibly increase species richness (Wright et al. 2002). These contrasting possibilities are cause for study in Canaan Valley, where little is known about the beaver population or its effects on the rare vegetative composition of the area. Inventories of vegetation in and around beaver ponds were conducted to establish if any rare plant communities are aided by beaver presence and to verify what compositional changes occur as a beaver inhabits an area. The objectives of this project include predicting the most likely areas of beaver use, then determining which vegetative groups will be affected by these 
population movements. We hypothesized that older ponds may provide a microhabitat for rare plant species and that these older impoundments would be predicted as highly suitable areas for beaver. The main objectives of my research were to:

1. Determine if beaver ponds are areas of high vegetative species richness and diversity;

2. Examine factors leading to vegetative community structure in areas associated with beaver impoundments; and

3. Create a probability map and model incorporating known habitat suitability factors and observational information and compare to the beaver habitat suitability index model.

\section{LITERATURE REVIEW}

\section{Beaver Natural History}

The genus Castor developed in the Pliocene and is represented today by two species: the North American beaver (Castor canadensis Kuhl) and the European beaver (Castor fiber). These closely related species show extremely similar morphological traits, to the extent that some continue to classify them as the same species (Müller-Schwarze and Sun 2003). The differing number of chromosomes in C. fiber $(2 \mathrm{~N}=40)$ and $C$. canadensis $(2 \mathrm{~N}=48)$ is one of the factors that led to classification as distinctive species. The beaver is the largest rodent species endemic to North America (Symington and Ruttan 1956). The North American beaver has 24 recognized subspecies, but boundaries between these groups are blurred due to transplanting and reintroduction efforts (Jenkins and Busher 1979). The species has a natural distribution that spans North America (Müller-Schwarze and Sun 2003), but they can presently be found in areas

of Eurasia due to introduction attempts (Nolet and Rosell 1998, Nitsche and Pachinger 2000). 
The North American beaver has historically been economically important in the United States. Pelts and furs were valuable for Native Americans as currency for bartering (Brown 2002). The North American beaver was a valuable and abundant resource, providing income for settlers and stimulating the colonial economy. Furs and pelts became important in European markets, spurring expansion and exploration in colonial North America to find desirable trapping locations (Wilson 2001). The North American population of beavers that once extended over 15 million square kilometers was nearly extirpated from its historical range by 1900 (Naiman et al. 1988) and was probably extinct in West Virginia by 1825 (Bailey 1954). Today, successful reintroduction projects, lack of trapping pressure from declining pelt prices, and absence of natural predators has led to an increase in beaver populations and re-colonization of most of their historic range (Bailey 1954, Naiman et al. 1988, Bhat et al. 1993, Brown 2002).

Beavers are semi-aquatic rodents and always found near some water source. The beaver will be found in streams, ponds, and large lakes throughout North America. They are only absent in areas that lack a constant water supply or open waters, such as the desert or tundra environments (Jenkins and Busher 1979). Beaver can live in riverbanks, but in mountainous areas they will build dams to impound water. Physical factors, such as stream depth and width, determine suitable dam-building areas. Vegetation is an important factor as a source for dam materials, but its role as a food source may be unimportant in terms of providing suitable habitat (Barnes and Mallik 1997). When the dam is built, the area is flooded, increased sediments are retained, and new aquatic and emergent vegetation communities form. These new habitat patches support new diverse plant communities and form a more heterogeneous landscape while providing a suitable aquatic resource for beavers (Johnston and Naiman 1990, Snodgrass 1997, Wright et al. 2002). 
The beaver is one of the most extensively studied furbearers in North America. It is generally accepted that beavers live in family units, often referred to as colonies (Novak 1999). This family unit is often composed of the reproductive male and female adults, the yearlings (offspring from the previous year), and the kits of the current year (Aleksiuk 1968). The family unit defends the general area where most daily movements occur. This is mostly accomplished using scent communication to avoid the intrusion of unknown beavers into the territory (Aleksiuk 1968). Each beaver has a distinctive scent, and family members can recognize other members of their colony based upon scent alone (Dietland-Müller and Sun 2003). Because it discourages intrusion, this behavior has been credited as a method of reducing intra-specific conflict, and there is evidence that this territoriality also may limit population density (Nolet and Rosell 1994).

Habitat Requirements and Suitability

Water is a requirement for suitable beaver habitat. Beavers inhabit lakes, rivers, streams, and wetlands. Beavers in small streams and wetlands impound water to create the cover requirements necessary for survival and reproduction (Allen 1983). Small mountainous streams may be impounded by beavers, but gradient plays a role in beaver inhabitance. Low gradient streams, particularly $\leq 4 \%$, are most often affected by beaver flooding. However, streams with up to a $17 \%$ grade have been known to be impounded by beavers in mountainous areas of California (Beier and Barrett 1987).

In colder climates, ice forms over beaver ponds, effectively trapping the colony members underwater. To keep a constant food source, beavers create a winter food cache consisting of woody plants. The cache is constructed beside or nearby one lodge. All individuals in the 
family stay in that one lodge, to retain warmth in the lodge and to remain close to the cache. In warmer regions, herbaceous vegetation may remain a food source and open waters are always available. These conditions make constructing a food cache unnecessary (Novak 1999).

The construction of winter food caches has led to several food preference studies. Doubt has been thrown on the results of these studies because most methods use the assumption that all trees cut were used as a food source (Slough 1978). It has been suggested that the floating mats created to submerge the food caches are composed of woody materials that are greatly different from the materials that compose the caches (Slough 1978). Despite these doubts, it is generally accepted that aspen is the woody food of choice for beavers in most areas (Brenner 1962), with willow (Salix spp.) and cottonwood (Populus balsamifera) also being important food sources (Allen 1983). However, in West Virginia woody food selection was identified for serviceberry (Amelanchier laevis), willow (Salix ssp.), black cherry (Prunus serotina), yellow birch (Betula alleghaniensis), black birch (Betula lenta), witch hazel (Hamamelis virginiana), and alder (Alnus incana) (Swank 1949). Distances to adequate food sources also may limit beavers. Fryxell and Doucet (1991) found that beaver are central-place foragers, with foraging activities concentrated in a core area that will expand to include other forage opportunities based on the size, type, and distance of woody species available.

The need for enough woody materials to create an adequate food cache makes the abundance of woody species a limiting factor in beaver habitat suitability, but the most preferred food supply is herbaceous and aquatic vegetation (Allen 1983). In areas that experience a winter freeze, the use of herbaceous vegetation during warmer periods also increases the amount of woody materials available for the winter cache (Brenner 1967). In areas with mild winters, where food caching is unnecessary, beavers will forage throughout the year on herbaceous 
matter. Herbaceous vegetation is never considered a limiting factor for habitat suitability, and the absence of preferred woody species does not indicate the absence of beaver. Beaver are an abundant resource in the south, in areas where aspen is never encountered. Despite clear preferences for certain vegetative types, the diversity of foods consumed throughout seasons and geographic areas proves the beaver to be a choosy generalist herbivore (Jenkins and Busher 1979).

The ecological effects of beavers are significant and often beneficial to wetland communities. In locations of beaver activity, the area of wetlands increase as beaver create previously unavailable open habitat patches (Wright et al. 2002). Beaver modify and create new habitats. Beaver alterations have the potential to produce both positive and negative impacts on the animal and the ecosystem (Jones et al. 1997). Beaver actively create a dam to flood the area, but the dam then creates changes in sediment deposition, altering physical characteristics of the soil and stream (Naiman et al. 1988). The potential for change in vegetative characteristics and diversity due to beaver has been well established. Their herbivory alone may not completely change community structure (Donkor and Fryxell 1999), but long-term cutting of preferred food types, lodge, and dam materials can significantly alter boreal forest composition (Naiman et al. 1986, Barnes and Dibble 1988). Beaver flooding in bogs of the northeastern United States can cause dramatic shifts in vegetation types and diversity, creating new fens as the soil is enriched (Mitchell and Niering 1993). These flooded pond areas also accumulate seed banks, which lead to germination and new vegetation growth when low water levels occur (Le Page and Keddy 1998). Moreover, several studies have shown the importance of beaver ponds in changing habitat use by and species composition of bird, reptile, and fish communities (Medin and Clary 1990, Brown et al. 1996, Snodgrass and Meffe 1998, Russell et al. 1999). These communities 
are affected when beavers abandon the area. In Colorado, abandoned beaver ponds led to a decrease in breeding ducks and muskrats (Ondatra zibethicus) that were abundant in active ponds (Neff 1957). Changes in community structure are not limited to compositional alterations. Nummi and Pöysä (1997) found that the patch disturbance caused by beavers leads to changes in the dominance structures of some wildlife guilds. Beaver ponds examined by Schlosser (1995) showed that beavers provide reproductive source areas for fish assemblages and are important for regulating fish dispersal. Although managed to reduce interference with human activities, beavers in the northeast are an important ecological presence, with behaviors and environmental alterations affecting both the floral and faunal communities that share their habitat.

Modeling and Geographic Information Systems

Beaver habitat use and quality have been modeled throughout North America using various techniques and measures (Allen 1983, Beier and Barrett 1987, Suzuki and McComb 1998). A Geographic Information Systems (GIS) approach was used by Macdonald et al. (2000) to assess suitable reintroduction sites of European beaver (Castor fiber) in Scotland. However, no general habitat suitability map has been created for the North American beaver. Modeling attempts have often involved complicated mathematical formulas and statistics that provide little visual context to model results (see Howard and Larson 1985). A habitat suitability index (HSI) for beaver was created (Allen 1983), based on general habitat characteristics. This model was developed for general use throughout the distribution of this species. However, this model lacks field validation. An alternate HSI was created for beaver habitat in the Oregon Coastal Range (Suzuki and McComb 1998). This model concentrated on characteristics that affected dam establishment rather than likely areas of use once pond impoundments have been created. 
Geographic information systems are often used to create predictive habitat maps for management of some species of concern (Gabler et al. 2000). These mapping efforts can be particularly effective when habitat requirements of the target species are well known (Gurnell et al. 2001, Osborne et al. 2001). These techniques have been shown as effective in modeling several species, including great bustards (Otis tarda) (Osborne et al. 2001) and endangered pygmy rabbits (Brachylagus idahoensis) (Gabler et al. 2000). Modeling using a GIS-based approach is becoming more frequent and accurate as digital datasets improve.

Study Area

Canaan Valley is an anticline valley located in Tucker County, West Virginia, USA. The elevation of the valley reaches $1,006 \mathrm{~m}$. The precipitation during the average annual growing season is $36.5 \mathrm{~cm}$ and the average temperature is $17.7^{\circ} \mathrm{C}$ (Regional Climate Center). During winter the average temperature is $-3.5^{\circ} \mathrm{C}$ (National Climate Data Center), and the freeze-free period lasts an average of 90 days (Beverage 1967).

The overall composition of vegetation in Canaan Valley can be considered boreal (Fortney 1993). Beaver impoundments are often dominated by herbaceous communities such as Carex spp. and Juncus effusus and by scrub-shrub communities, such as Spiraea alba. The current vegetation in the valley is likely dissimilar to conditions previous to logging, fires, and attempts at agricultural land use practices. However, the valley floor now contains the largest freshwater wetland complex in mid-Appalachia (Fig. 2). Over 50 rare plant species (Fig. 3) and 30 rare plant communities (Fig. 4) have been identified within the valley. Much of the floristic diversity in the area may be attributed to both the wetland habitats available and the occurrence of many northern species at the southernmost bounds of their ranges (Fortney 1993). While many of these species and communities are widespread and globally secure, they are unusual on 
a state level with many occurring only in Canaan Valley. Moreover, some of these species occur in abundance in the valley, although sparse elsewhere in West Virginia, leading to their consideration as rare plants for this area.

Much of the valley is now part of Canaan Valley National Wildlife Refuge (Fig. 5). The 6,169 ha refuge was established in 1994 and contains much of the wetland areas in the central and northern portions of the valley. The Blackwater River runs through much of the refuge and is fed by several drainages along its path. Beaver activity is centered in several of these smaller drainages but occurs throughout the valley. The number of beaver ponds in the valley has increased from 113 in 1945 to 222 by 2003.

\section{LITERATURE CITED}

Aleksiuk, M. 1968. Scent mound communication, territoriality, and population regulation in beaver (Castor canadensis Kuhl). Journal of Mammalogy 49:759-762.

Allen, A. W. 1983. Habitat suitability index models: Beaver. U.S. Fish and Wildlife Service. FWS/OBS-82/10.30 Revised. 20pp.

Anderson, J. T., J. S. Rentch, W. P. Grantham, and R. H. Fortney. 2003. Influence of nutrient availability, hydrology, and beaver on plant community distribution in Canaan Valley, West Virginia. Unpublished Report.

Bailey, R. W. 1954. Status of beaver in West Virginia. Journal of Wildlife Management 18:184-190.

Barnes, W. J. and E. Dibble. 1988. The effects of beaver in riverbank forest succession. Canadian Journal of Botany 66:40-44. 
Barnes, D. M. and A.U. Mallik. 1997. Habitat factors influencing beaver dam establishment in a northern Ontario watershed. Journal of Wildlife Management 61:1371-1377.

Beier, P. and R. H. Barrett. 1987. Beaver habitat use and impact in the Truckee River Basin, California. Journal of Wildlife Management 51:794-799.

Beverage, W. 1967. Soil survey, Tucker County, part of northern Randolph County, West Virginia. USDA Soil Conservation Service, and Forest Service, Washington, DC.

Bhat, M., R. G. Huffaker, and S.M. Lenhart. 1993. Controlling forest damage by dispersive beaver populations: Centralized optimal management strategy. Ecological Applications 3:518-530.

Brenner, F. J. 1962. Food consumed by beavers in Crawford County, Pennsylvania. Journal of Wildlife Management 26:104-107.

Brenner, F. J. 1967. Spatial and energy requirements of beavers. Ohio Journal of Science 67:242-246.

Brooks, M. 1957. Canaan Valley. West Virginia Conservation 21:7-10.

Brown, C. 2002. Beavers in Rhode Island: A guide to history, behavior, and coping with problems associated with beaver activities. RI Department of Environmental Management's Division of Fish and Wildlife. Wildlife Leaflet No. 21

Brown, D. J., W.A. Hubert, and S.H. Anderson. 1996. Beaver ponds create wetland habitat for birds in mountains of southeastern Wyoming. Wetlands 16:127-133.

Donkor, N. T. and J. M. Fryxell. 1999. Impact of beaver foraging on structure of lowland boreal forests of Algonquin Provincial Park, Ontario. Forest Ecology and Management 118:8392. 
Fortney, R. H. 1993. Canaan Valley - An area of special interest within the upland forest region. In S. L. Stephenson (ed.) Upland Forests of West Virginia. McClain Printing Co., Parsons, West Virginia, USA.

Fortney, R. H. and J. S. Rentch. 2003. Post logging era plant successional trends and geospatial vegetation patterns in Canaan Valley, West Virginia, 1945 to 2000. Castanea 68:317-334.

Fryxell, J. M. and C. M. Doucet. 1991. Provisioning time and central-place foraging in beavers. Canadian Journal of Zoology 69:1308-1313.

Gabler, K. I., J. W. Laundré, and L.T. Heady. 2000. Predicting the suitability of habitat in southeast Idaho for pygmy rabbits. Journal of Wildlife Management 64:759-764.

Howard, R. J. and J. S. Larson. 1985. A stream habitat classification system for beaver. Journal of Wildlife Management 49:19-25.

Jenkins, S. H. and P. E. Busher. 1979. Castor canadensis. Mammalian Species 120:1-8.

Johnston, C. A. and R. J. Naiman. 1990. Aquatic patch creation in relation to beaver population trends. Ecology 71:1617-1621.

Jones, C. G., J. H. Lawton, and M. Shachak. 1997. Positive and negative effects of organisms as physical ecosystem engineers. Ecology 78:1946-1957.

Le Page, C. and P. A. Keddy. 1998. Reserves of buried seeds in beaver ponds. Wetlands 18:242248.

Macdonald, D. W., F. H. Tattersall, S. Rushton, A.B. South, S. Rao, P. Maitland, and R. Strachan. 2000. Reintroducing the beaver (Castor fiber) to Scotland: a protocol for identifying and assessing suitable release sites. Animal Conservation 3:125-133.

Medin, D. E. and W. P. Clary. 1990. Bird populations in and adjacent to a beaver pond ecosystem in Idaho. United State Forest Service Research Paper INT 432. 
Mitchell, C. C. and W. A. Niering. 1993. Vegetation change in a topogenic bog following beaver flooding. Bulletin of the Torrey Botanical Club 120:136-147.

Müller-Schwarze, D. and L. Sun. 2003. The beaver: natural history of a wetlands engineer. Cornell University Press, Ithaca, NY.

Naiman, R. J., C. A. Johnston, and J. C. Kelley. 1988. Alteration of North American streams by beaver. Bioscience 38:753-762.

Naiman, R. J., J. M. Melillo, and J. E. Hobbie. 1986. Ecosystem alteration of boreal forest streams by beaver (Castor canadensis). Ecology 67:1254-1269.

National Climate Data Center (NCDC), National Oceanographic and Atmospheric Administration (NOAA). 2003. http://www1.ncdc.noaa.gov/pub/orders.

Neff, D. J. 1957. Ecological effects of beaver habitat abandonment in the Colorado Rockies. Journal of Wildlife management 21:80-84.

Nitsche, K. A. and K. Pachinger. 2000. Status, expansion, and perspectives of the beaver (Castor fiber) population in Slovakia. Game and Wildlife Science 17(3):165-176.

Nolet, B. A. and F. Rosell. 1998. Comeback of the beaver Castor fiber: an overview of old and new conservation problems. Biological Conservation 83(2):165-173.

Novak, M. 1999. Chapter 25: Beaver. p. 282-312. In M. Novak, J.A. Baker, M.E. Obbard, and B. Malloch (eds.) Wild Furbearer Management and Conservation in North America. Queen's Printer, Ontario, Canada.

Nummi, P. and H. Pöysä. 1997. Population and community level responses in Anas-species to patch disturbance caused by an ecosystem engineer, the beaver. Ecography 20:580-584. 
Osborne, P. E., J. C. Alonso, and R.G. Bryant. 2001. Modeling landscape-scale habitat use using GIS and remote sensing: a case study with great bustards. Journal of Applied Ecology $38: 458-471$.

Russell, K. R., C. E. Moorman, J.K. Edwards, B.S. Metts, and D. C. Guynn, Jr. 1999. Amphibian and reptile communities associated with beaver (Castor canadensis) ponds and unimpounded streams in the piedmont of South Carolina. Journal of Freshwater Ecology $14: 149-158$.

Schlosser, I. J. 1995. Dispersal, boundary processes, and trophic-level interactions in streams adjacent to beaver ponds. Ecology 76:908-925.

Slough, B. G. 1978. Beaver food cache structure and utilization. Journal of Wildlife Management 42:644-646.

Snodgrass, J. W. 1997. Temporal and spatial dynamics of beaver-created patches as influenced by management practices in a south-eastern North American landscape. Journal of Applied Ecology 34:1043-1056.

Snodgrass, J. W. and G.K. Meffe. 1998. Influence of beavers on stream fish assemblages: Effects of pond age and watershed position. Ecology 79:928-942.

Southeast Regional Climate Center. 1996. http://www.dnr.sc.gov/climate/sercc/index.html

Suzuki, N. and W. C. McComb. 1998. Habitat classification models for beaver (Castor canadensis) in the streams of the central Oregon coast range. Northwest Science 72:102110.

Swank, W. G. 1949. Beaver ecology and management in West Virginia. Conservation Commission of West Virginia, Division of Game Management, Bulletin No. 1. 
Symington, D. F. and R. A. Ruttan. 1956. Beavers in Saskatchewan. Saskatchewan Department of Natural Resources, Conservation Bulletin no. 1. 18 pp.

Wilson, J. M. 2001. Beavers in Connecticut: Their natural history and management. Connecticut Department of Environmental Protection, Wildlife Division. Hartford, CT. 18pp.

Wright, J. P., C. G. Jones, and A. S. Flecker. 2002. An ecosystem engineer, the beaver, increases species richness at the landscape scale. Oecologia 132:96-101. 


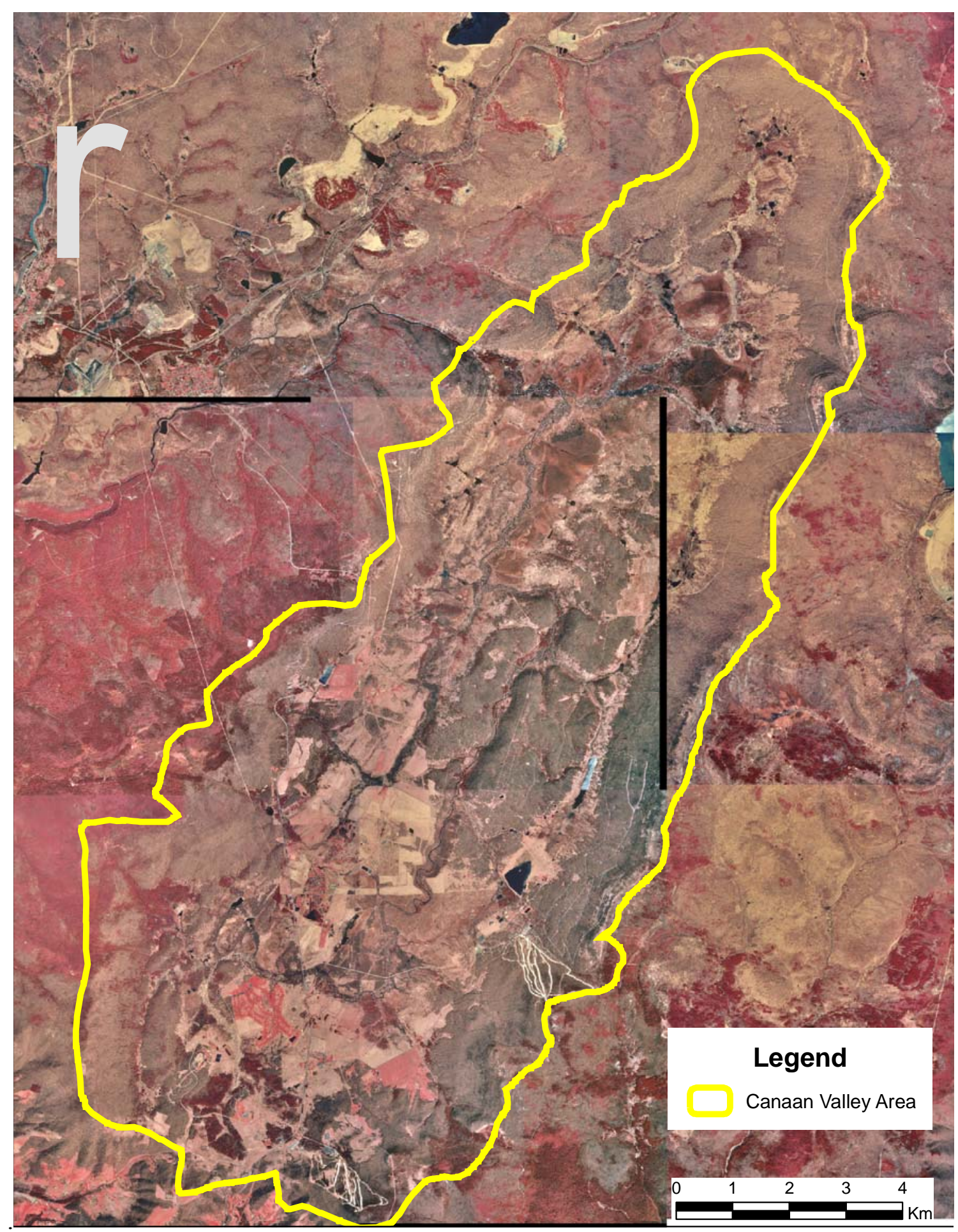

Figure 1. Arial photography showing the Canaan Valley, West Virginia, USA area. Yellow line indicates boundary of Canaan Valley. 


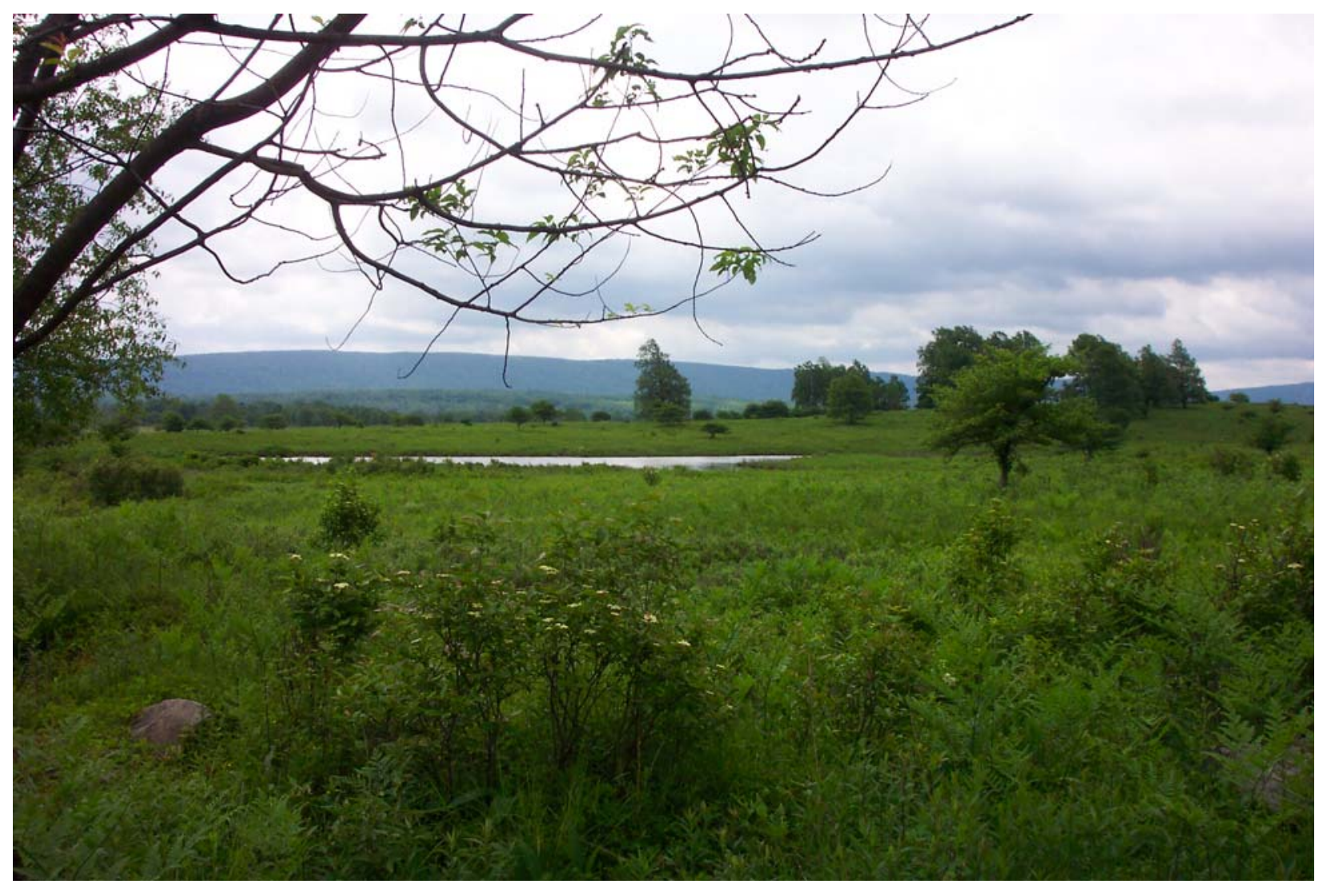

Figure 2. A beaver pond complex created on a small tributary of the Blackwater River in Canaan Valley, West Virginia, USA. 


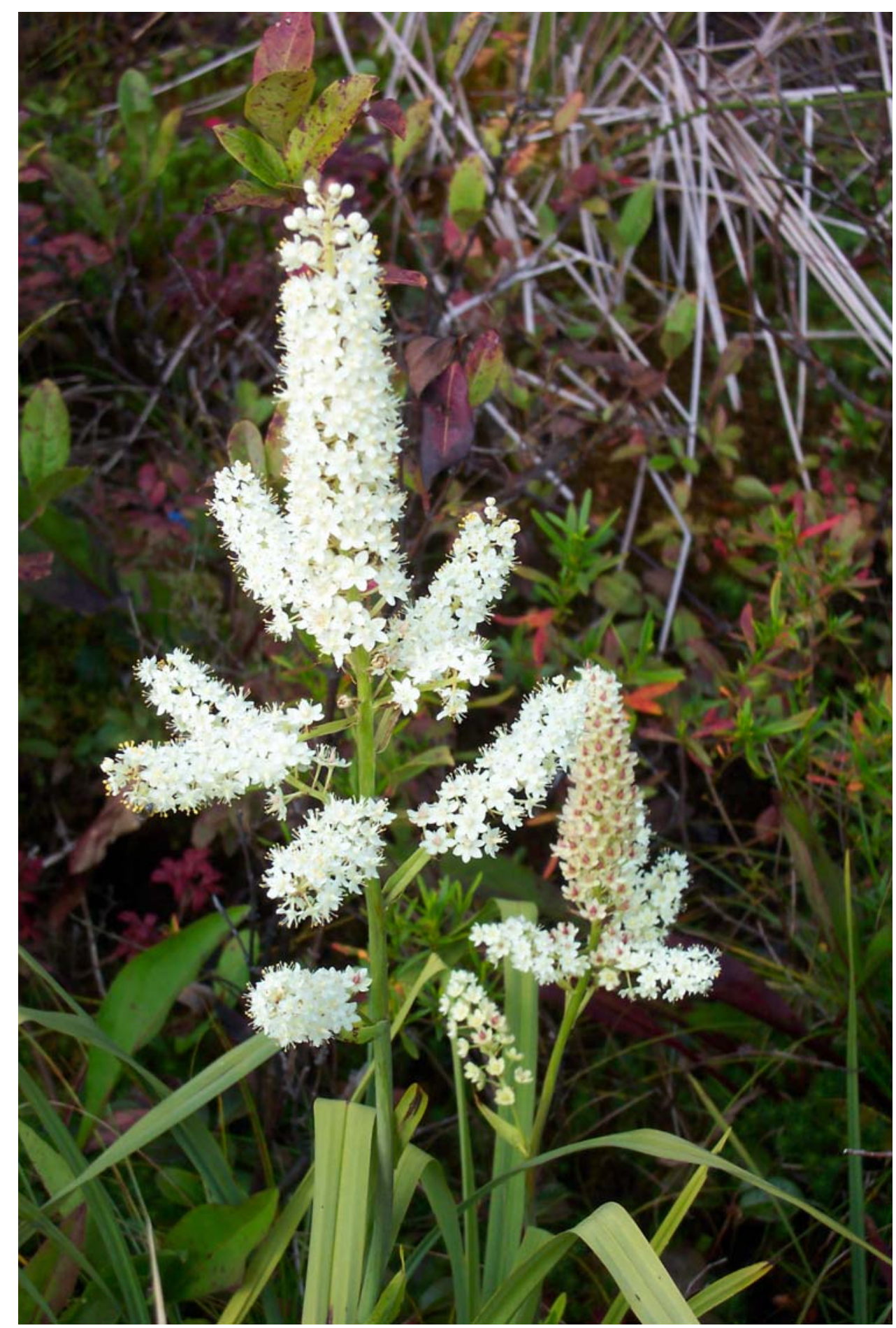

Figure 3. Oceanurus (Zigadenus leimanthoides) is one of over 50 rare plant species found in several locations throughout Canaan Valley, West Virginia, USA. 


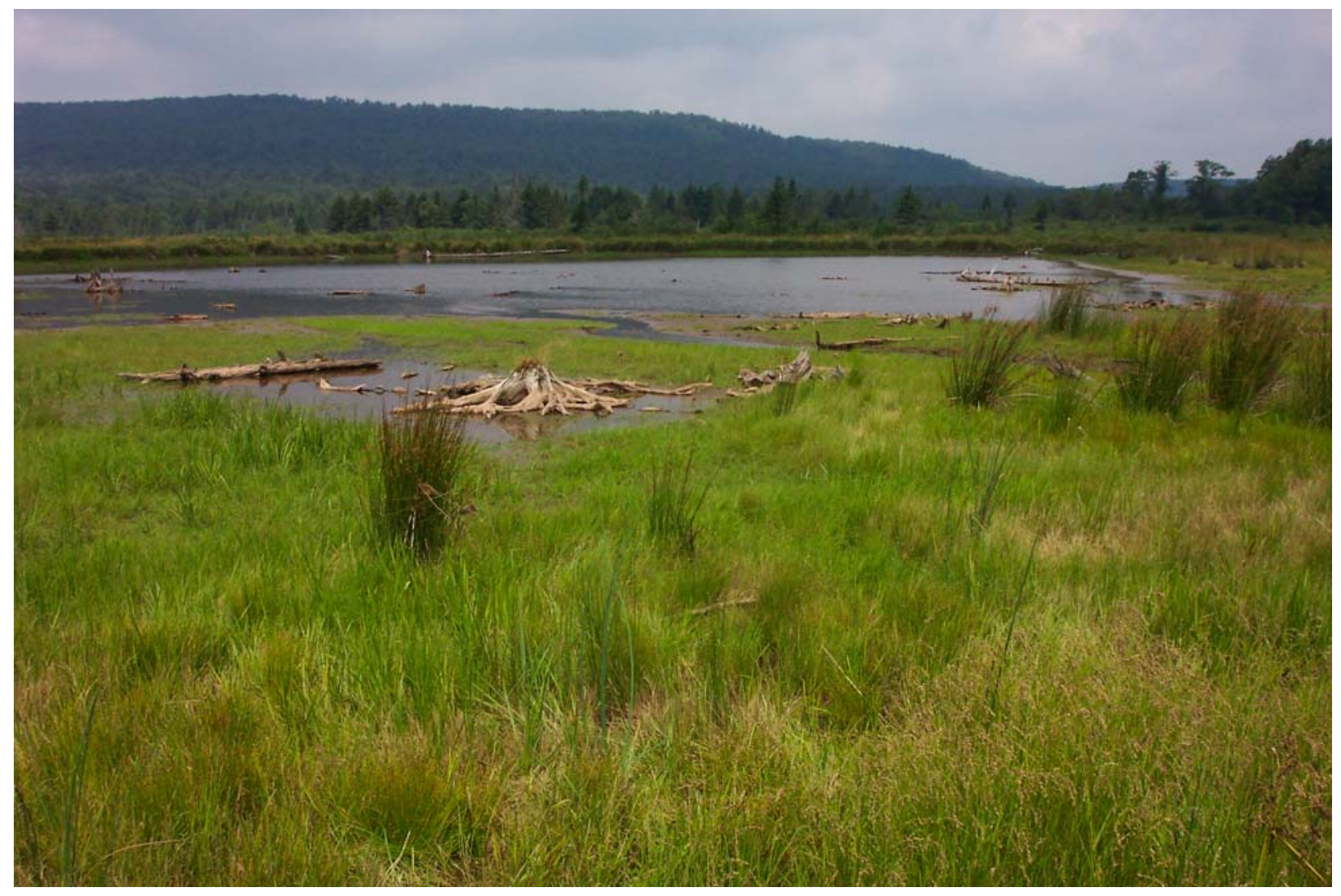

Figure 4. Some rare plant communities occur around or nearby beaver impoundments, such as Juncus spp. communities present in the foreground and red spruce (Picea rubens) in the distance. 


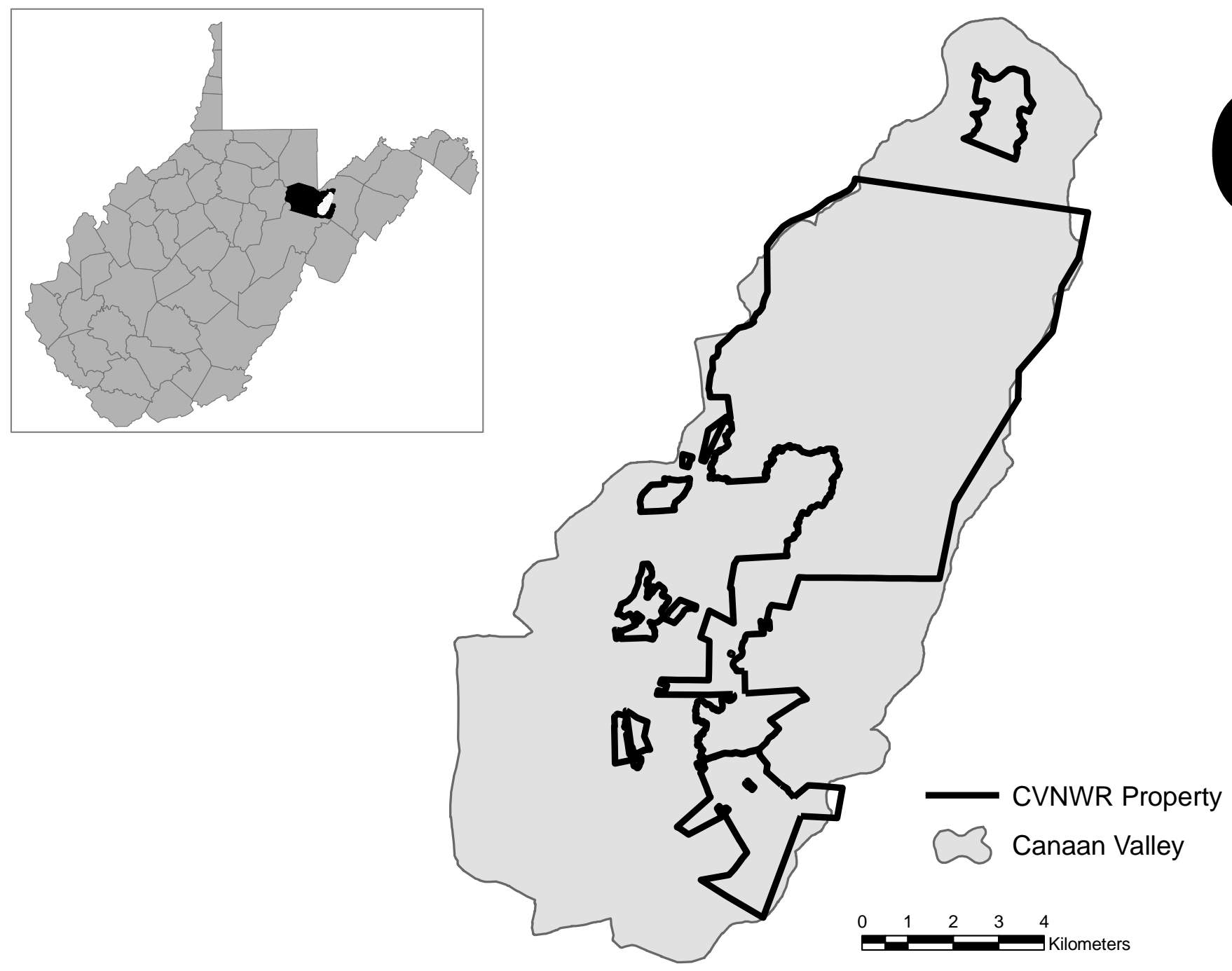

Figure 5. Canaan Valley National Wildlife Refuge (CVNWR) boundaries are shown in black over the gray area of Canaan Valley. Inset shows Canaan Valley located in Tucker County, WV, USA 


\title{
CHAPTER II
}

\section{VEGETATIVE COMPOSITION AND COMMUNITY STRUCTURE ASSOCIATED WITH BEAVER PONDS IN CANAAN VALLEY, WEST VIRGINIA, USA.}

\author{
Jerri L. Bonner, James T. Anderson ${ }^{1}$, James S. Rentch, and William N. Grafton \\ West Virginia University \\ Division of Forestry, Wildlife and Fisheries Resources Program \\ P.O. Box 6125 \\ Morgantown, WV 26506 \\ ${ }^{1}$ corresponding author \\ Email: jander25@wvu.edu
}

Abstract: Beavers (Castor canadensis) can cause dramatic changes in vegetative composition and diversity. Although vegetative impacts of beaver have been studied extensively, little attention has been paid to the effects beaver impoundments have on rare plant communities. Effective conservation of riparian and wetland rare plant species must consider the flooding that can occur when beaver populations are present. The goal of this research was to establish rare plant species occurrence, examine community composition, and analyze vegetative community structure of vegetation associated with beaver ponds in Canaan Valley, West Virginia, USA. Species richness and diversity were similar in all areas sampled, regardless of the influence of the beaver pond $(P>0.05)$. Although no significant difference in rare plant species was detected among pond ages, there was a trend of increasing rare plant species with increasing pond age. Youngest ponds showed highest mean species richness (S'), but trends showed S' returning to similar levels at the oldest ponds $(P<0.05)$. Multiple response permutation procedure (MRPP) analyses of community structure detected no relation between community composition and either pond age or size. However, both MRPP and non-metric multi-dimensional scaling showed proximity to pond was important in herbaceous community structure. Moreover, use of weighted averages indicated higher quality wetland communities closer to beaver

This manuscript prepared using the format of the journal Wetlands. 
impoundments. These data show beaver ponds to be distinct communities from adjacent wetland areas. We found that the oldest ponds may be an important habitat, harboring greater numbers of rare plant species, such as Carex atherodes and Scirpus microcarpus. Newly formed ponds provided high species richness, but they contained the fewest number of rare species. Trapping of beaver may be advisable in newly dammed areas to protect desired rare plant species and/or communities that are flood intolerant, but conservation of beaver populations is necessary so that older ponds containing higher numbers of rare plant species may persist.

Key Words: Canaan Valley, Castor canadensis, Pond, Rare Plant Species, Vegetation

\section{INTRODUCTION}

Beavers (Castor canadensis Kuhl) are a natural influence on streams and wetlands across much of North America. The dam-building activities of these semi-aquatic mammals alter forest succession by flooding areas (Barnes and Dibble 1988, Naiman et al. 1988), leading to changes in sediment retention, invertebrate communities, vegetative composition, and stream morphology (Naiman et al. 1986, Wright et al. 2002). Herbivory by beavers also can have a dramatic effect on successional trends along streams (Barnes and Dibble 1988).

Although beaver activities were once a natural influence on a relatively unaltered landscape (Naiman et al. 1988), today they are a potential hindrance to typical successional patterns (Balcombe 2003). Although beaver ponds may typically be short-term $(<10$ years) in terms of beaver use (Wright et al. 2002), Naiman et al. (1988) indicate the potential for beaverinduced community types, such as fens and wet meadows, to be enduring stages of succession instead of temporary patches. This observation may be applicable to our study area, where some beaver impoundments have persisted for at least 56 years. Thus, the current sub-climax 
community could be long-term if beaver flooding and herbivory suppress the growth of the local climax plant communities. Long-term changes in vegetation communities and succession have been documented in Colorado after beaver inhabitance (Neff 1957).

Although potentially disruptive, the ecological effects of beavers are significant and often beneficial to wetland communities. Beavers increase wetland area by creating new wetlands from upland or riparian areas (Wright et al. 2002). Beaver have the ability to modify and create new habitats, with the potential to produce both positive and negative impacts on the animal and the ecosystem (Jones et al. 1997). Beavers in wetlands and small-order streams may create dams to impound water, thereby creating changes in sediment deposition and altering physical characteristics of the soil and stream (Naiman et al. 1988). Some studies have documented substantial increases in species richness (Wright et al. 2002) and changes in species composition (Mitchell and Niering 1993). Although beaver herbivory alone may not completely change community structure (Donkor and Fryxell 1999), beaver flooding in bogs of the northeastern United States caused dramatic shifts in habitat types and diversity, creating new fens and supporting more hydric species (Mitchell and Niering 1993). These flooded pond areas also accumulate seed banks, which lead to germination and new vegetation growth when changes in water levels occur (Le Page and Keddy 1998). Although managed to reduce interference with human activities, beavers in the northeast are an important ecological presence, with behaviors and environmental alterations affecting floristic communities that share their habitat.

The vegetative communities influenced by beavers require evaluation, given that in many habitats beaver activities may lead to local declines of certain species (Mitchell and Niering 1993). However, on a landscape level, beaver activity can increase species richness (Wright et al. 2002). Additionally, the impacts of beaver ponds on rare vegetation and community 
composition have not been well described. Given the unusual longevity of some impoundments, we hypothesize that older ponds may be a microhabitat for rare plant species. Our objectives of this study were to (1) establish vegetative species composition and richness of beaver pond areas; (2) determine importance of pond age and size to rare plant species; and (3) examine the effects of pond age and size on pond community structure.

\section{METHODS}

Study Site

This study took place in Canaan Valley, located in Tucker County, West Virginia, USA. Canaan Valley is a large (22.5 km long, $5 \mathrm{~km}$ wide) anticline valley at an elevation of up to $1,006 \mathrm{~m}$. The precipitation during summer months (June-August) averages $36.5 \mathrm{~cm}$ and the average temperature is $17.7^{\circ} \mathrm{C}$ (Southeast Regional Climate Center 1996). During winter (December-March) the average temperature is $-3.5^{\circ} \mathrm{C}$ (National Climate Data Center 2003), and the freeze-free period lasts an average of 90 days (Beverage 1967). The Blackwater River runs through much of the valley and is fed by several drainages along its path. Beaver activity is centered in several of these smaller drainages.

The vegetation of Canaan Valley can be considered boreal in overall composition (Fortney 1993). Wetland areas with beaver ponds are often dominated by herbaceous communities such as Carex spp. and Juncus effusus and by scrub-shrub communities, particularly Spiraea alba. Although the valley may have been more forested in the past, the valley floor now contains one of the largest freshwater wetland complexes in the eastern United States. Over 50 rare plant species, including 36 rare wetland plant species, have been identified within the valley, as well as 35 rare plant communities. Much of the floristic diversity in the area 
may be attributed to the wetland habitats available. Additionally, many northern species occur at the southernmost bounds of their ranges in the valley (Fortney 1993). These factors lead to communities and species that, while globally abundant, are rare for the local area and the state of West Virginia.

Plant communities such as red spruce (Picea rubens) forests are still present in Canaan Valley, but the abundance has been greatly reduced due to extensive logging. Fortney and Rentch (2003) cite beaver activity as a possible influence in a $>40 \%$ loss in developing coniferous forests. Although extirpated from West Virginia in the 1850 s, beavers were reintroduced to the Canaan Valley area of West Virginia around 1936 (Swank 1949). Although some communities seem to be slowly returning to the valley (Brooks 1957), Fortney and Rentch (2003) suggested beaver presence as one factor leading to the decreased abundance of several rare plant communities in the valley since 1975.

All surveys were conducted on beaver ponds located in Canaan Valley National Wildlife Refuge. The refuge was established in 1994. The 6,169 ha refuge contains much of the wetland areas in the central and northern portions of the valley. Wetland areas where most beaver activity occurs was acquired in early 2002, with beaver trapping being prohibited within refuge boundaries until the 2004-2005 season.

Vegetation Sampling

Vegetation surveys were conducted in 2004 and 2005 on 38 randomly selected beaver ponds, stratified by size class in relative proportion to abundance: 6 large $\left(>4,000 \mathrm{~m}^{2}\right), 11$ medium $\left(>1,000-4,000 \mathrm{~m}^{2}\right)$, and $21 \mathrm{small}\left(>100-1,000 \mathrm{~m}^{2}\right)$ (Figure 1). Total number of ponds on the refuge was composed of 16 large (11\%), 42 medium (29\%), and 86 small (60\%). 
Sampling occurred from June-September 2004 and June 2005. All ponds smaller than $100 \mathrm{~m}^{2}$ were removed from sampling selection as surveyors would likely be unable to find those patches. All pond features were digitized and areas were calculated using the program ArcMap 9.1 (ESRI 2005).

Three belt transects were used to sample vegetation at each pond. The three transect directions were selected from eight possible ordinal compass bearings. Bearings that crossed the main dam of the pond were excluded. Each transect ran along a randomly selected direction, beginning at the edge of the open water. Transects extended beyond the end of the influence of the pond to capture two additional herbaceous plots. We considered the influence of the pond to end when a distinct change in vegetative community occurred, most often due to a clear increase in gradient. We used $1.0 \times 1.0 \mathrm{~m}$ herbaceous plots every $5 \mathrm{~m}$ and 5.0 × $5.0 \mathrm{~m}$ shrub plots every $10 \mathrm{~m}$ along each transect. Within all herbaceous plots, a cover class was assigned for each observed vascular species, bryophytes, woody debris, bare ground, and open water. The following cover class scale was used to estimate cover: $1-5 \%=1,6-25 \%=2,26-50 \%=3,51$ $75 \%=4,76-95 \%=5,96-100 \%=6($ Daubenmire 1968). In shrub plots, these cover classes were used to estimate cover of any shrub species present. Walk-around surveys also were used at each pond to capture any species not observed within transect plots (Balcombe et al. 2005). These surveys were typically conducted within $5 \mathrm{~m}$ of the pond, with observers documenting all species that were not recorded along transects. Plant species were identified using Strausbaugh and Core (1977), and nomenclature was standardized according to Kartesz (1999).

Age classes were determined by digitizing all visible ponds from four sets of aerial photographs $(1945,1969,1997,2003)$. The program ArcMap 9.1 was used to overlay all 
digitized pond polygons and compare the relative temporal occurrence of each pond. Broad age classes were determined as follows: $1-6,>6-35,>35-56$, and $>56$ years.

Statistical Analyses

The program PC-Ord was used to calculate species richness (S') and the ShannonWeaver index of diversity (H', Shannon and Weaver 1949) (dependent variables) for each quadrat. Location inside vs. outside of beaver ponds was our independent variable. Data were analyzed using an analysis of variance (ANOVA, PROC GLM) in the statistical software SAS (SAS Institute Inc. 2003). Data were tested for normality and homogeneity of variances.

Rare plant richness per pond was rank-transformed using SAS (PROC RANK) because data would not meet assumptions of a parametric test, then compared by age class using ANOVA (PROC GLM). All species occurring in transects or walk-around surveys were included and analyzed per pond. An ANOVA was used to compare mean species richness (dependent variable) of herbaceous communities among age and size classes (independent variables). All interaction effects were tested for significance. An alpha level of 0.05 was considered significant for all tests. All data are presented as untransformed means.

Community structure analyses of ponds based on (1) location around beaver pond, (2) age class and, (3) size class were performed using Multiple Response Permutation Procedures (MRPP) in PC-Ord (McCune and Mefford 1999). Multi-response permutation procedures test the hypothesis that no difference exists between species composition of selected areas. This is a non-parametric multivariate technique requiring a priori selection of test areas (location, age, and size). This procedure calculates a T-statistic, a $P$-value, and an A-statistic. Separation between groups is described by the T-statistic. The likelihood of reaching the observed difference ( $T$ ) is evaluated using the $P$-value. The A-statistic estimates within-group 
homogeneity compared to what is expected by chance, with $A=1$ in completely identical plots and $\mathrm{A}=0$ in those communities equal to chance expectation. The Sørenson (Bray-Curtis) dissimilarity index was used during these tests. The Sørenson index is considered suitable for ecological data, as it performs better in more heterogeneous datasets and is not as sensitive to outliers as other indices (McCune and Mefford 1999).

Non-metric multi-dimensional scaling (NMS) was used to analyze community composition of each pond relative to location in relation to the pond. This technique is considered most effective and is recommended for community data ordination (McCune et al. 2002). We used PC-Ord v.4 for autopilot NMS analysis, which uses 40 runs of real data, 400 maximum iterations, and 50 runs of randomized data in a Monte Carlo test (McCune and Mefford 1999). In the final ordination a 3-dimension solution was used along with the best starting point from the initial analyses. We report the final stress and coefficients of determination $\left(\mathrm{R}^{2}\right)$ for the two most explanatory axes. The two most explanatory axes were analyzed for species composition trends based on groupings of ponds along each axis.

Covariance within vegetation datasets was reduced by eliminating species occurring at less than seven ponds. Mantel tests were conducted to verify no significant differences in data after removal of uncommon species. Shrub and herbaceous cover for each species was calculated based on the mid-point of each cover class rating. These values were ranktransformed during analysis to limit the loss of distance sensitivity as the heterogeneity of communities increases (McCune et al. 2002). Herbaceous analysis was limited to plots within the influence of a pond, as this area was found to be different in species composition than outside areas. Herbaceous vegetation and shrub cover were grouped and analyzed using pre-defined size and age classes. 
We used weighted averages (Atkinson et al. 1993, Balcombe et al. 2005) to analyze quality of herbaceous wetland communities inside and outside the influence of each pond. Averages were calculated using a combination of species coverage and wetland indicator status (WIS) values. The following WIS values were given to each species: $1=$ obligate, $2=$ facultative wetland, 3 = facultative, $4=$ facultative upland, and $5=$ upland (U.S. Fish and Wildlife Service 1996). We then calculated weighted averages using the formula:

$$
\text { Weighted average }=\frac{\left(\mathrm{y}_{1} \mathrm{u}_{1}+\mathrm{y}_{2} \mathrm{u}_{2}+\ldots \ldots \mathrm{y}_{\mathrm{m}} \mathrm{u}_{\mathrm{m}}\right)}{100}
$$

where $\mathrm{y}=$ relative cover estimates per species and $\mathrm{u}=$ the WIS value per species (Atkinson et al. 1993). A paired $t$-test was used to compare mean weighted averages of vegetative communities inside and outside the influence of beaver ponds.

\section{RESULTS}

We recorded 203 plant species during 38 pond surveys. Of these species, 15 are considered rare (Table 1), of 36 rare wetland plant species known to occur in the valley (Appendix 1). Most commonly occurring herbaceous species included Rubus hispidus and Solidago uliginosa (Table 2, Appendix 2), and the most common woody species was Spiraea alba (Appendix 3). Walk around surveys captured 48 species that were not observed in herbaceous or shrub plots along transects (Appendix 4).

There were no differences between mean $\mathrm{S}^{\prime}\left(\mathrm{F}_{1,699}=0.49, P=0.485\right)$ and $\mathrm{H}^{\prime}\left(\mathrm{F}_{1,699}=\right.$ $0.00, P=0.955)$ in areas influenced by beaver ponds compared to areas not influenced by ponds (Table 3). Among age and size classes, herbaceous communities associated with ponds were similar in $\mathrm{S}^{\prime}$ (age: $\mathrm{F}_{3,29}=0.09, P=0.967$; size: $\mathrm{F}_{2,29}=1.14, P=0.335$ ) and $\mathrm{H}^{\prime}$ (age: $\mathrm{F}_{3,29}=0.25$, 
$P=0.863$; size: $\mathrm{F}_{2,29}=0.12, P=0.890$ ). Rare plant occurrence also showed no significant differences among pond age classes $\left(\mathrm{F}_{3,34}=1.38, P=0.266\right)$, but increasing mean rare plant species in the oldest age class. Additionally, our results show no significant difference in total herbaceous and shrub $\mathrm{S}^{\prime}$ among size classes $\left(\mathrm{F}_{2,35}=0.63, P=0.539\right)$ but show age classes having a significant effect on $\mathrm{S}^{\prime}\left(\mathrm{F}_{3,34}=3.28, P=0.033\right)$. Post-hoc analysis shows similar higher richness in youngest and oldest ponds (Table 3). Average percent cover was higher in areas not influenced by ponds $\left(t_{37}=-4.09, P<0.001\right)$, but was similar among age classes $\left(\mathrm{F}_{3,34}=2.69, P=\right.$ $0.062)$. Although percent hydrophyte cover was also similar among age classes $\left(F_{3,34}=0.66, P=\right.$ $.584)$, it was greater in areas influenced by ponds $\left(\mathrm{t}_{37}=5.67, \mathrm{P}<0.001\right)$. Overall, results indicate that while all areas are diverse habitats, shorter-lived ponds provide habitat for a wide range of species, while the oldest ponds may have some importance as a microhabitat for rare plants.

Weighted averages were calculated for 38 ponds using cover estimates of 150 herbaceous species. Mean averages for communities inside $(\overline{\mathrm{x}}=1.020, \mathrm{SE}=0.071)$ and outside $(\overline{\mathrm{x}}=2.053$, $\mathrm{SE}=0.145$ ) were both below 3.0 , indicating all communities support predominantly hydrophytic vegetation (Kindscher et al. 1998). Results showed significantly lower values $\left(t_{37}=-6.64, P<\right.$ 0.001) for herbaceous communities associated with beaver ponds (Table 3 ). This indicates more obligate wetland communities when influenced by beaver impoundments.

Multi-response permutation procedures were run using total vegetative occurrence and using rank-transformed shrub and herbaceous cover (Table 4). An analysis of herbaceous communities based on proximity to beaver ponds showed an influence of location on the vegetative community composition $(P<0.001)$. Our MRPP results of vegetation occurrence shows no significant influence of size $(P=0.095)$ or age $(P=0.503)$ on herbaceous community 
structure around beaver ponds. Similar results were found for shrub community composition based on age $(P=0.357)$ and size $(P=0.840)$ classes.

Our 3-axis NMS analysis of 38 ponds had a final stress of 13.668. Stress values of less than 20 are considered fairly reliable for community data (McCune et al. 2002). Axis $2\left(\mathrm{R}^{2}=\right.$ $0.271)$ and $3\left(R^{2}=0.432\right)$ explained the greatest variation in our data; the combination of all 3 axes explained $84.8 \%$ of the variation in our data. Communities more distant from the pond were not as tightly grouped, but are clearly different from those inside the pond's influence

(Figure 2). Axis 2 had the greatest negative correlation with bryophytes $(\mathrm{r}=-0.68)$ and Solidago uliginosa $(\mathrm{r}=-0.559)$ and the strongest positive correlation with Eleocharis obtusa $(\mathrm{r}=0.486)$. Open water $(r=-0.550)$ and Carex canescens $(r=-0.395)$ were most negatively associated with axis 3, while Rubus hispidus $(\mathrm{r}=0.791)$, Solidago rugosa $(\mathrm{r}=0.601)$, and Euthamia graminifolia $(\mathrm{r}=0.460)$ showed the strongest positive correlations (Table 5). Axis 2 showed no strong correlations to particular species or cover types; however, axis 3 was strongly correlated with less obligate wetland species, including Pteridium aquilinum $(\mathrm{r}=0.427)$, a facultative upland species, while the negative correlations found for this axis were mainly obligate wetland species and open water. This indicates a moisture gradient, increasing from the top of the axis (further from open water) to the bottom of the axis (approaching the pond).

\section{DISCUSSION}

The beaver ponds in Canaan Valley create high quality wetland habitats that differ in species composition from those areas not impacted by beaver impoundments. As most community changes were distinct upon gradient changes, topography and the resulting hydrology may be important factors in this analysis of community composition. Basin morphology was 
found to be an important factor in vegetative composition in New Hampshire (Koning 2005). In our study, younger ponds (1-6 yrs) show a higher species richness than ponds 7-56 years of age. This distinction may be explained simply by the ponds being new to the landscape. When flooding occurs, established species are eventually displaced and replaced by more water-tolerant species (Mitchell and Niering 1993). The high species richness associated with these youngest ponds may be attributed to a combination of new species growth along with species remaining from periods before inundation. We document a decrease in $S^{\prime}$ in the next two older age classes. Balcombe et al. (2005) cites the possibility of competitive exclusion occurring as wetlands age, which could explain the age classes harboring fewer species. While S' was significantly lower for two middle age groups, the oldest ponds show mean S' that is similar to the high levels found in the youngest beaver ponds. This eventual increase in S' may be due to stabilization of the wetland area after disturbance. In created wetlands, older ponds have been shown to have higher levels of organic matter (Atkinson and Cairns 2001), which is necessary for wetland stabilization (Balcombe et al. 2005). Similar richness in youngest and oldest ponds also may represent a similar recruitment from the present seed bank. While seed banks have not been shown to increase in richness with pond age, older ponds retain the same potential for seed germination compared to younger ponds (Le Page and Keddy 1998).

Vegetative community structure is an important indicator of wetland function (Balcombe et al. 2005), and may affect the community composition of other guilds, particularly invertebrates (Anderson and Smith 2000). Proximity to impoundment was found to be a significant factor in determining herbaceous community composition. Our MRPP comparison of surveys inside and outside the influence of impounded water indicates a community shift occurs as distance from ponds increases. This is supported by NMS analysis of these communities and 
examination using weighted averages. The most explanatory axis (Axis 3) describes almost half of the variation in pond vegetation $\left(\mathrm{R}^{2}=0.473\right)$. We believe this axis to be representative of a decreasing water level as distance from a pond increases. The most positively correlated species include facultative and facultative wetland species, as well as obligate wetland species. However, negative correlations are exclusive to obligate wetland species and open water. Moreover, weighted averages indicate that areas outside the pond's influence are more facultative wetland habitats than those communities influenced by beaver ponds. This shift in wetland status of these species is probably due to more species being adapted to long-term saturation or inundation near beaver ponds. A difference in both structure and fidelity of wetland vegetation in areas influenced by beaver ponds indicates this habitat provides unique conditions for certain communities.

However, our MRPP analyses showed no significant influence of pond age or size on community composition. Although this does not preclude their having a role in community structure, this does indicate that any role would be small in comparison with other factors. The more important impact of the pond itself may be that changes occur to soil properties in proximity to flooding. Activity levels, as well as abandonment, were not used as qualifications for pond surveys. The potential differences in abandoned beaver ponds are great. Beaver foraging activity, or lack thereof, could affect nutrient flow in surrounding areas (Johnston and Naiman 1987), thereby affecting present vegetative composition. Some ponds, although still retaining water, could have been in an alternate successional stage due to recent abandonment, thus affecting our analysis of community structure. Vegetative communities are often dictated by soil nutrients, type, and moisture (Barbour et al. 1987). These factors were not sampled during this study. However, they have the potential to influence species composition, growth, 
and persistence. Future studies of vegetation in beaver habitats may require the incorporation of these variables into sampling and analyses.

Although rare plant species do not occur in significantly higher numbers in these impoundments, there are clear trends indicating older ponds as a refuge for greater numbers of these species. We believe the lack of significance can be contributed to the small number of rare plant species observed, a problem inherent in sampling rare species (Steidl et al. 1997). Older ponds were found to harbor some rare plant species not found elsewhere in our study area. One such species, Carex atherodes, is the southernmost population in its distribution and the only location known in West Virginia. Several rare plant species and communities occur at the periphery of their range in our study area. In a study of a perennial rare plant species Lychnis viscaria, peripheral populations experienced lower genetic diversity than central populations and genetic isolation was greater than expected by distance between populations (Lammi et al. 1999). These details may be significant for Canaan Valley, where so many rare plant species and rare plant communities occur (see Fortney 1975). However, Lammi et al. (1999) also found that peripheral populations could maintain similar fitness levels as core populations. This finding may suggest that other rare plant populations, such as those found in Canaan Valley, are still viable and may be able to expand or persist with conservation efforts.

Although older ponds may harbor more rare plant species, there is a lack of conifer species in areas near beaver impoundments. Only four observations of conifer species were recorded for all 38 ponds sampled. Although a spruce-hemlock (Picea rubens-Tsuga canadensis) forest is historically reported to be the major forest cover type on the valley floor (Brooks 1957), only two observations of eastern hemlock and no red spruce observations were recorded during pond surveys. Although no direct evidence of negative effects on conifers, our 
low occurrence of conifers may lend support to Fortney and Rentch's (2003) suggestion of coniferous community declines due to beaver activity. Alternatively, this may be due to more widespread changes as we did not sample areas away from beaver ponds.

\section{Management Implications}

Management of beaver populations is recommended in Canaan Valley National Wildlife Refuge. Wetlands typically contain rich, diverse floristic communities. In addition, this study area also harbors many statewide or regionally rare plant species and communities. Rare wetland species may be adversely affected by a range of conditions, from trampling (Koning 2005) to low genetic diversity (Lammi et al. 1999). As these factors likely affect plant communities in Canaan Valley, beaver population management may be necessary to benefit particular rare plant species in general and to protect developing coniferous communities in particular.

Our data suggests a trend of older ponds providing refuge for more rare plant species. One such species, Carex atherodes, occurs at the periphery of its range, as do many species in this area. These peripheral populations of rare plants are more isolated and typically small and may be experiencing low genetic diversity (see Lammi et al. 1999). As such, protection and management of the habitats in which they occur is necessary to conserve these rare wetland plant species. Geomorphology, particularly areas that allow large, expandable impoundments, is a determining factor in beaver habitat use, as these areas will be inhabited first (Johnston and Naiman 1990). Similar events seem to have occurred in our study area, where most large ponds were created early and most long-term ponds are shown to be highly suitable beaver habitat (Bonner 2005, Chapter 3). We believe that limited and highly regulated trapping in these areas 
would not adversely affect the longevity of these ponds, as they should be the preferred refuge

for the remaining beaver population. Moreover, reduction in the beaver population may prevent losses of some species of concern, as fewer new areas should be flooded. In areas where conservation of flood-intolerant species is desirable, it may be advisable to use techniques to deter beaver activity, in addition to more liberal trapping regulations.

\section{ACKNOWLEDGMENTS}

Funding and logistical support for this project was provided by the Canaan Valley Institute, the Cooperative State Research, Education, and Extension Service, the Regional Research Institute of West Virginia University, and the West Virginia University Division of Forestry. We thank Dr. John Edwards for review of this manuscript. We thank Dr. George Seidel for statistical guidance. We thank Canaan Valley National Wildlife Refuge for access to our study sites and support of this research. This is scientific article number xxxx of the West Virginia University Agricultural and Forestry Experiment Station.

\section{LITERATURE CITED}

Anderson, J. T. and L. M. Smith. 2000. Invertebrate response to moist-soil management of playa wetlands. Ecological Applications 10:550-558.

Atkinson, R. B., J. E. Perry, E. Smith, and J. Cairns. 1993. Use of created wetland delineation and weighted averages as a component of assessment. Wetlands 13:185-193. 
Atkinson, R. B. and J. Cairns, Jr. 2001. Plant decomposition and litter accumulation in depressional wetlands: functional performance of two wetland age classes that were created via excavation. Wetlands 21:354-362

Balcombe, C. K. 2003. An evaluation of vegetation and wildlife communities in mitigation and natural wetlands of West Virginia. M. S. Thesis. West Virginia University, Morgantown, WV, USA.

Balcombe, C. K., J. T. Anderson, R. H. Fortney, J. S. Rentch, W. N. Grafton, and W. S. Kordek. 2005. A comparison of plant communities in mitigation and reference wetlands in the mid-Appalachians. Wetlands 25:130-142.

Barbour, M. G., J. H. Burk, and W. D. Pitts. 1987. Terrestrial Plant Ecology, second edition. The Benjamin/Cummings Publishing Company, Inc., Menlo Park, CA, USA.

Barnes, W. J. and E. Dibble. 1988. The effects of beaver in riverbank forest succession. Canadian Journal of Botany 66:40-44.

Beverage, W. 1967. Soil survey, Tucker County, part of northern Randolph County, West Virginia. USDA Soil Conservation Service, and Forest Service, Washington, DC.

Bonner, J. L. 2005. The influence of beaver impoundments on vegetative composition, and modeling habitat suitability as a tool for wildlife management and conservation. M. S. Thesis, West Virginia University, Morgantown, WV, USA.

Brooks, M. 1957. Canaan Valley. West Virginia Conservation 21:7-10.

Daubenmire, R. F. 1968. Plant Communities, A Textbook of Synecology. First edition. Harper and Row Publishers, New York, NY, USA. 
Donkor, N. T. and J. M. Fryxell. 1999. Impact of beaver foraging on structure of lowland boreal forests of Algonquin Provincial Park, Ontario. Forest Ecology and Management 118:8392.

ESRI. 2005. ArcMap 9.1 GIS. ESRI Inc, Redlands, California, USA.

Fortney, R. H. 1975. A vegetation survey of Canaan Valley, West Virginia. Ph.D. dissertation, West Virginia University, Morgantown, West Virginia, USA.

Fortney, R. H. 1993. Canaan Valley - An area of special interest within the upland forest region. In S. L. Stephenson (ed.) Upland Forests of West Virginia. McClain Printing Co., Parsons, West Virginia, USA.

Fortney, R. H. and J. S. Rentch. 2003. Post logging era plant successional trends and geospatial vegetation patterns in Canaan Valley, West Virginia, 1945 to 2000. Castanea 68:317334.

Johnston, C. A. and R. J. Naiman. 1987. Boundary dynamics at the aquatic-terrestrial interface: The influence of beaver and geomorphology. Landscape Ecology 1:47-57.

Johnston, C. A. and R. J. Naiman. 1990. Aquatic patch creation in relation to beaver population trends. Ecology 71:1617-1621.

Jones, C. G., J. H. Lawton, and M. Shachak. 1997. Positive and negative effects of organisms as physical ecosystem engineers. Ecology 78:1946-1957.

Kartesz, J. T. 1999. A synonymized checklist and atlas with biological attributes for the vascular flora of the United States, Canada, and Greenland, first edition. In J. T. Kartesz and C. A. Meachum (eds.) Synthesis of the North American Flora, Version 1.0. North Carolina Botanical Garden, University of North Carolina, Chapel Hill, NC, USA. 
Kindscher, K., A. Fraser, M.E. Jakubauskas, and D.M. Debinski. 1998. Identifying wetland meadows in Grand Teton National Park using remote sensing and average wetland values. Wetlands Ecology and Management 5:265-273,

Koning, C. O. 2005. Vegetation patterns resulting from spatial and temporal variability in hydrology, soils, and trampling in an isolated basin marsh, New Hampshire, USA. Wetalnds 25:239-251.

Lammi, A., P. Siikamäki, and K. Mustajärvi. 1999. Genetic diversity, population size, and fitness in central and peripheral populations of a rare plant Lychnis viscaria. Conservation Biology 13:1069-1078.

Le Page, C. and P. A. Keddy. 1998. Reserves of buried seeds in beaver ponds. Wetlands $18: 242-248$.

McCune, B. and R. Mefford. 1999. PC-ORD. Multivariate Analysis of Ecological Data, Version 4. MjM Software Design, Gleneden Beach, OR, USA.

McCune, B., J. B. Grace, and D. L. Urban. 2002. Analysis of Ecological Communities. MjM Software Design, Gleneden Beach, OR, USA.

Mitchell, C. C. and W.A. Niering. 1993. Vegetation change in a topogenic bog following beaver flooding. Bulletin of the Torrey Botanical Club 120:136-147.

Naiman, R. J., J. M. Melillo, and J. E. Hobbie. 1986. Ecosystem alteration of boreal forest streams by beaver (Castor canadensis). Ecology 67:1254-1269.

Naiman, R. J., C. A. Johnston, and J. C. Kelley. 1988. Alteration of North American streams by beaver. BioScience 38:753-762.

National Climate Data Center (NCDC). 2003. National Oceanographic and Atmospheric Administration (NOAA). http://www1.ncdc.noaa.gov/pub/orders. 
Neff, D.J. 1957. Ecological effects of beaver habitat abandonment in the Colorado Rockies. Journal of Wildlife Management 21:80-84.

SAS Institute Inc. 2003. SAS software. Cary, North Carolina, USA.

Shannon, C. E. and W. Weaver. 1949. The Mathematical Theory of Communication. University of Illinois Press, Urbana, IL, USA.

Southeast Regional Climate Center. 1996. http://www.dnr.sc.gov/climate/sercc/index.html

Steidl, R. J., J. P. Hayes, and E. Schaber. 1997. Statistical power analysis in wildlife research. Journal of Wildlife Management 61:270-279.

Strausbaugh, P. D., and E. L. Core. 1977. Flora of West Virginia. Seneca Books, Inc., Morgantown, WV, USA.

Swank, W. G. 1949. Beaver ecology and management in West Virginia. Conservation Commission of West Virginia, Division of Game Management, Bulletin No. 1.

U.S. Fish and Wildlife Service. 1996. National list of vascular plant species that occur in Wetlands: 1996 national summary. U.S. Fish and Wildlife Service, Washington DC, USA.

Wright, J. P., C. G. Jones, and A. S. Flecker. 2002. An ecosystem engineer, the beaver, increases species richness at the landscape scale. Oecologia 132:96-101. 
Table 1. Rare plant species observed during transect and walk-around surveys of beaver ponds in Canaan Valley, West Virginia, USA, 2004-2005. Nomenclature follows Kartesz (1999).

\begin{tabular}{|c|c|c|c|c|c|}
\hline Species Name & Common Name & Observations $^{\mathrm{a}}$ & WIS $^{b}$ & Global $^{\mathrm{c}}$ & State $^{\mathrm{d}}$ \\
\hline Abies balsamea & Balsam fir & 2 & Fac & G5 & S3 \\
\hline Campanula aparinoides & Marsh bellflower & 2 & Obl & G5 & S3 \\
\hline Carex atherodes & Awned sedge & 1 & Obl & G5 & $\mathrm{S} 1$ \\
\hline Carex canescens & Hoary sedge & 24 & Obl & G5 & S3 \\
\hline Carex comosa & Bearded sedge & 1 & Obl & G5 & $\mathrm{S} 2$ \\
\hline Carex projecta & Necklace sedge & 1 & Facw & G5 & $\mathrm{S} 1$ \\
\hline Drosera rotundifolia & Sun dew & 3 & Obl & G5 & $\mathrm{S} 3$ \\
\hline Glyceria grandis & American mannagrass & 5 & Obl & G5 & $\mathrm{S} 2$ \\
\hline Glyceria laxa & Northern mannagrass & 1 & NL & G5 & $\mathrm{S} 1$ \\
\hline Juncus filiformis & Thread rush & 1 & Facw & G5 & $\mathrm{S} 2$ \\
\hline Salix discolor & Glacous willow & 2 & Facw & G5 & $\mathrm{S} 2$ \\
\hline Scirpus atrocinctus & Black-girdle bulrush & 19 & Facw + & G5 & $\mathrm{S} 3$ \\
\hline Scirpus microcarpus & Small-flowered bulrush & 14 & Obl & G5 & $\mathrm{S} 3$ \\
\hline Vaccinium macrocarpon & Small cranberry & 4 & Obl & G4 & $\mathrm{S} 2$ \\
\hline Veronica scutellata & Marsh speedwell & 3 & Obl & G5 & S1 \\
\hline
\end{tabular}

Observations is the number of ponds at which each species was observed.

b. WIS indicates the wetland indicator status of each species (U.S. Fish and Wildlife Service 1996). Possible status, in order of decreasing wetland fidelity: obligate (obl), facultative wetland (facw), facultative (fac), facultative upland (facu), and upland (upl). $\mathrm{NL}=$ not listed. 
Table 1. continued.

c. Global indicates the status of each species across its range: $G 1=$ critically impaired, G2= imperiled, G3= vulnerable, G4= apparently secure, G5= secure.

d. State shows the status of each species in West Virginia: S1= critically impaired; S2= imperiled, S3= vulnerable, S4= apparently secure, and S5= secure. 
Table 2. Most commonly occurring plant species (frequency) around beaver ponds in Canaan Valley, West Virginia, USA based on the number of ponds at which each species occurred.

Nomenclature follows Kartesz (1999).

\begin{tabular}{|c|c|c|c|c|}
\hline Scientific Name & Mean Cover $^{\mathrm{a}}$ & Standard Dev. & Maximum Cover ${ }^{c}$ & Ponds $^{\mathrm{d}}$ \\
\hline Rubus hispidus & 17.816 & 11.981 & 47.22 & 36 \\
\hline Solidago uliginosa & 7.662 & 7.637 & 25.83 & 31 \\
\hline Juncus effusus & 2.710 & 2.970 & 13.18 & 31 \\
\hline Glyceria canadensis & 2.341 & 3.825 & 16.55 & 30 \\
\hline Triadenum virginicum & 1.394 & 2.016 & 7.50 & 29 \\
\hline Hypericum ellipticum & 0.979 & 1.925 & 10.50 & 29 \\
\hline Carex scoparia & 0.919 & 1.326 & 5.63 & 26 \\
\hline Solidago rugosa & 2.858 & 3.757 & 15.23 & 25 \\
\hline Gallium tinctorium & 1.407 & 2.572 & 14.07 & 25 \\
\hline Juncus subcaudatus & 1.188 & 1.865 & 8.41 & 25 \\
\hline Spiraea alba & 14.322 & 22.698 & 97.50 & 24 \\
\hline Carex canescens & 1.428 & 2.842 & 13.64 & 24 \\
\hline Danthonia compressa & 2.845 & 3.765 & 13.09 & 23 \\
\hline Carex echinata & 2.032 & 3.152 & 16.09 & 22 \\
\hline Sparganium erectum & 1.606 & 2.889 & 11.50 & 22 \\
\hline Pteridium aquilinum & 1.066 & 2.233 & 10.45 & 21 \\
\hline Polygonum satittatum & 0.282 & 0.457 & 1.81 & 21 \\
\hline Carex folliculata & 1.522 & 2.577 & 9.20 & 20 \\
\hline
\end{tabular}


Table 2. continued.

b

Standard Dev. is the standard deviation of cover percentage for each species.

c Maximum cover is the greatest cover percentage of each species for one pond

d Ponds is the number of ponds at which each species was observed. 
Table 3. Multiple analyses of vegetation data from Canaan Valley, West Virginia, USA, 2004-2005. Index represents the dependent variable being tested. Groups were tested between locations in relation to beaver ponds (plot location) and for differences among age (pond age) $)^{\mathrm{a}}$. All numbers shown are untransformed data.

\begin{tabular}{|c|c|c|c|c|c|c|c|c|c|c|c|c|}
\hline \multirow[b]{3}{*}{ Index } & \multicolumn{4}{|c|}{ Plot Location } & \multicolumn{8}{|c|}{ Pond Age (years) } \\
\hline & \multicolumn{2}{|c|}{ Inside } & \multicolumn{2}{|c|}{ Outside } & \multicolumn{2}{|c|}{$>56$} & \multicolumn{2}{|c|}{$>36-56$} & \multicolumn{2}{|c|}{$>6-36$} & \multicolumn{2}{|c|}{$\leq 6$} \\
\hline & $\overline{\mathrm{x}}$ & $\mathrm{SE}$ & $\overline{\mathrm{x}}$ & $\mathrm{SE}$ & $\overline{\mathrm{x}}$ & SE & $\overline{\mathrm{x}}$ & SE & $\overline{\mathrm{x}}$ & SE & $\overline{\mathrm{x}}$ & $\mathrm{SE}$ \\
\hline Total percent cover & $73.138_{\mathrm{a}}$ & 1.603 & $97.672_{b}$ & 2.966 & $80.521_{a}$ & 7.866 & $88.682_{\mathrm{a}}$ & 8.827 & $65.686_{a}$ & 5.095 & $57.563_{\mathrm{a}}$ & 13.559 \\
\hline Species richness/plot & $5.683_{\mathrm{a}}$ & 0.130 & $5.522_{\mathrm{a}}$ & 0.169 & $5.088_{b}$ & 0.238 & $5.459_{\mathrm{a}, \mathrm{b}}$ & 0.276 & $6.035_{\mathrm{a}}$ & 0.194 & $5.591_{\mathrm{a}, \mathrm{b}}$ & 0.426 \\
\hline Diversity/plot & $1.171_{\mathrm{a}}$ & 0.025 & $1.168 \mathrm{a}$ & 0.033 & $1.044_{b}$ & 0.049 & $1.116_{a, b}$ & 0.055 & $1.249 \mathrm{a}$ & 0.037 & $1.146_{a, b}$ & 0.083 \\
\hline Total species richness/pond ${ }^{\mathrm{b}}$ & - & - & - & - & $41.833_{\mathrm{a}, \mathrm{b}}$ & 4.020 & $35.00_{b}$ & 2.070 & $33.368_{b}$ & 2.930 & $49.60_{\mathrm{a}}$ & 5.163 \\
\hline Rare plant species richness ${ }^{\mathrm{b}}$ & - & - & - & - & $3.167 \mathrm{a}$ & 0.703 & $2.000_{\mathrm{a}}$ & 0.463 & $2.158_{a}$ & 0.336 & $1.400_{\mathrm{a}}$ & 0.510 \\
\hline Weighted averages & $1.020 \mathrm{a}$ & 0.071 & $2.053_{\mathrm{b}}$ & 0.145 & $1.106_{\mathrm{a}}$ & 0.114 & $1.343_{\mathrm{a}}$ & 0.228 & $0.915_{\mathrm{a}}$ & 0.073 & $0.798_{\mathrm{a}}$ & 0.177 \\
\hline \% Hydrophytic & $97.581_{\mathrm{a}}$ & 0.805 & $86.743_{b}$ & 2.023 & $98.606_{a}$ & 0.763 & $95.411_{\mathrm{a}}$ & 2.369 & $97.963_{\mathrm{a}}$ & 1.236 & $98.369_{\mathrm{a}}$ & 0.562 \\
\hline
\end{tabular}

${ }^{a}$ The same lower case letter following means indicate no significant differences between plot location or among pond ages $(P>0.05)$.

${ }^{\mathrm{b}}$ Data from walk around surveys are included. Plot location can not be determined. 
Table 4. Results of the Multiple Response Permutation Procedure (MRPP) testing the null hypothesis of no significant difference in herbaceous or shrub community composition between sites based on size and age classes and location in relation to beaver ponds in Canaan Valley, West Virginia, USA.

\begin{tabular}{|c|c|c|c|c|c|c|}
\hline & Distance $^{\mathrm{a}}$ & Obs. Delta ${ }^{b}$ & Exp. Delta ${ }^{c}$ & $A^{\mathrm{d}}$ & $T^{\mathrm{e}}$ & $P$-value ${ }^{\mathrm{f}}$ \\
\hline Age - Herbaceous & & 0.501 & 0.5 & -0.0029 & 0.097 & 0.503 \\
\hline$>56$ years & 0.395 & & & & & \\
\hline$>35-56$ years & 0.495 & & & & & \\
\hline$>6-35$ years & 0.526 & & & & & \\
\hline$\leq 6$ years & 0.547 & & & & & \\
\hline Size - Herbaceous & & 0.483 & 0.5 & 0.033 & -1.368 & 0.095 \\
\hline Small & 0.355 & & & & & \\
\hline Medium & 0.481 & & & & & \\
\hline Large & 0.559 & & & & & \\
\hline Age - Shrub & & 0.495 & 0.5 & 0.009 & -0.261 & 0.357 \\
\hline$>56$ years & 0.518 & & & & & \\
\hline$>35-56$ years & 0.543 & & & & & \\
\hline$>6-35$ years & 0.473 & & & & & \\
\hline$\leq 6$ years & 0.469 & & & & & \\
\hline Size - Shrub & & 0.513 & 0.5 & -0.0267 & 0.961 & 0.840 \\
\hline Small & 0.473 & & & & & \\
\hline Medium & 0.551 & & & & & \\
\hline Large & 0.465 & & & & & \\
\hline
\end{tabular}


Table 4. continued

\begin{tabular}{ccccccc}
\hline & Distance $^{\mathrm{a}}$ & Obs. Delta $^{\mathrm{b}}$ & Exp. Delta $^{\mathrm{c}}$ & $A^{\mathrm{d}}$ & $T^{\mathrm{e}}$ & $P_{\text {-value }}^{\mathrm{f}}$ \\
\hline Location - Herbaceous & & 0.398 & .5 & 0.202 & -23.266 & $<0.001$ \\
Inside & 0.433 & & & & & \\
Out & 0.362 & & & & & \\
& & & & & & \\
\hline
\end{tabular}

a. Distance is the mean Sørenson distance between each combination of quadrats from each size or age class.

b. Observed delta is determined from sample data;

c. Expected delta is calculated from a null distribution;

d. $A$ is the chance-corrected within-group agreement;

e. $T$ is the MRPP test statistic.

f. $P$-value was significant at 0.05 for all tests. 
Table 5. Correlations of herbaceous species and cover types associated with two primary axes in non-metric multi-dimensional scaling (NMS) ordination for beaver ponds in Canaan Valley, West Virginia, USA. Nomenclature follows Kartesz (1999).

\begin{tabular}{lccc}
\hline Species Name & Correlation $^{\mathrm{a}}$ & Status $^{\mathrm{b}}$ & Axis $^{\mathrm{c}}$ \\
\hline Bryophytes & -0.68 & 2 \\
Solidago uliginosa & -0.556 & obl & 2 \\
Open water & -0.553 & & 3 \\
Carex canescens & -0.398 & obl & 3 \\
Bryophytes & -0.352 & & 3 \\
Carex folliculata & -0.321 & obl & 2 \\
Leersia oryzoides & -0.318 & obl & 3 \\
Gallium tinctorum & 0.376 & obl & 2 \\
Dichanthelium clandestinum & 0.394 & fac + & 3 \\
Pteridium aquilinum & 0.429 & facu & 3 \\
Leersia oryzoides & 0.459 & obl & 2 \\
Euthamia graminifolia & 0.466 & fac & 3 \\
Rock/Bare ground & 0.498 & fac & 2 \\
Eleocharis obtusa & 0.501 & obl & 2 \\
Solidago rugosa & 0.607 & 3 \\
Rubus hispidus & 0.792 & 3 \\
\hline
\end{tabular}

a. Correlation is the r-value of each species or cover type. Most strongly correlated $(r>0.30)$ species are shown.

b. Wetland indicator status is shown for each species (U.S. Fish and Wildlife Service 1996). 
Table 5. continued.

Possible status, in order of decreasing wetland fidelity: obligate (obl), facultative wetland (facw), facultative (fac), facultative upland (facu), and upland (upl).

c. Axis indicates the ordination axis to which the species or cover type is correlated. 


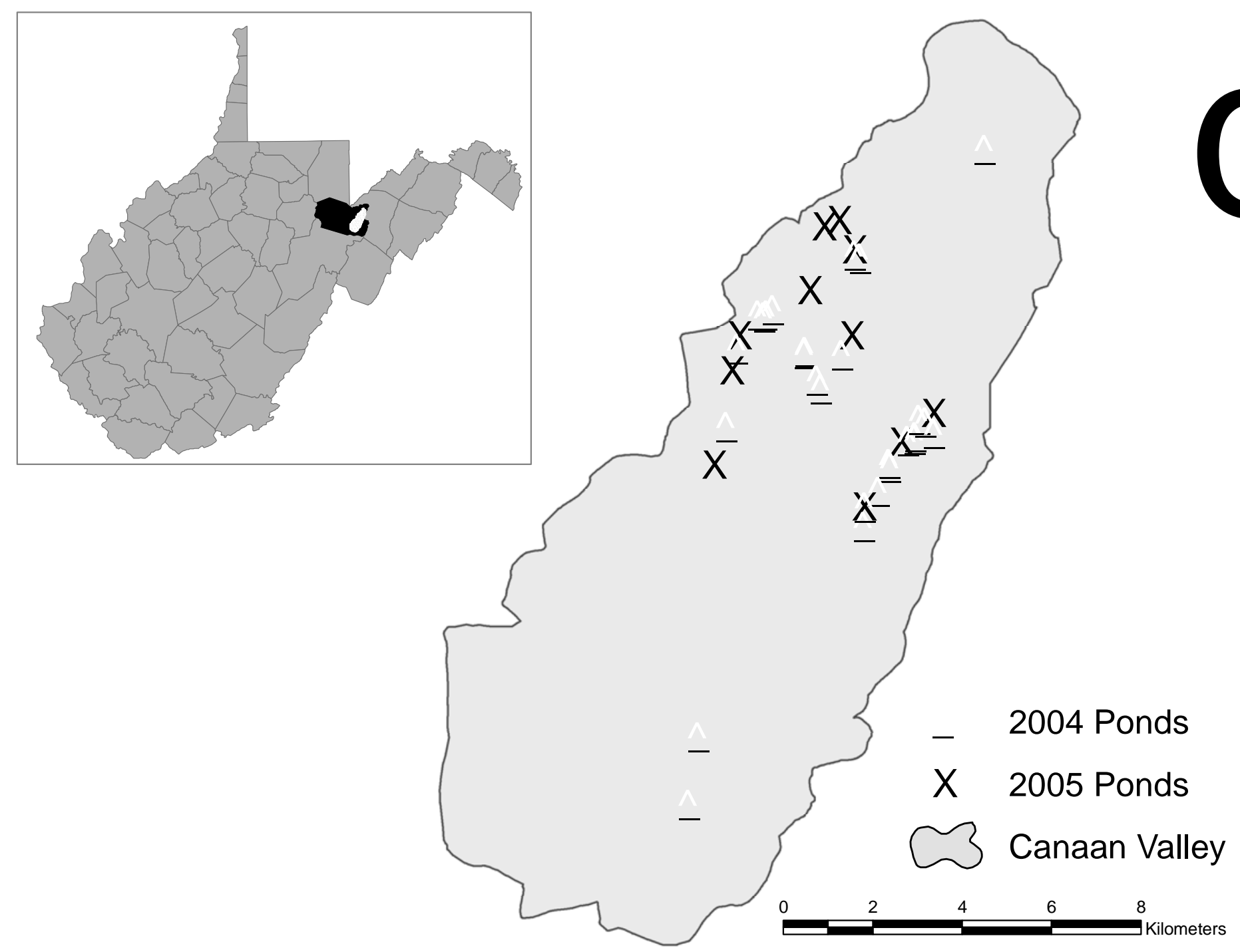

Figure 1. Location of beaver ponds surveyed for vegetation in 2004 (black dashes with white carets) and 2005 (black crosses) in Canaan Valley (Tucker County), West Virginia, USA. 


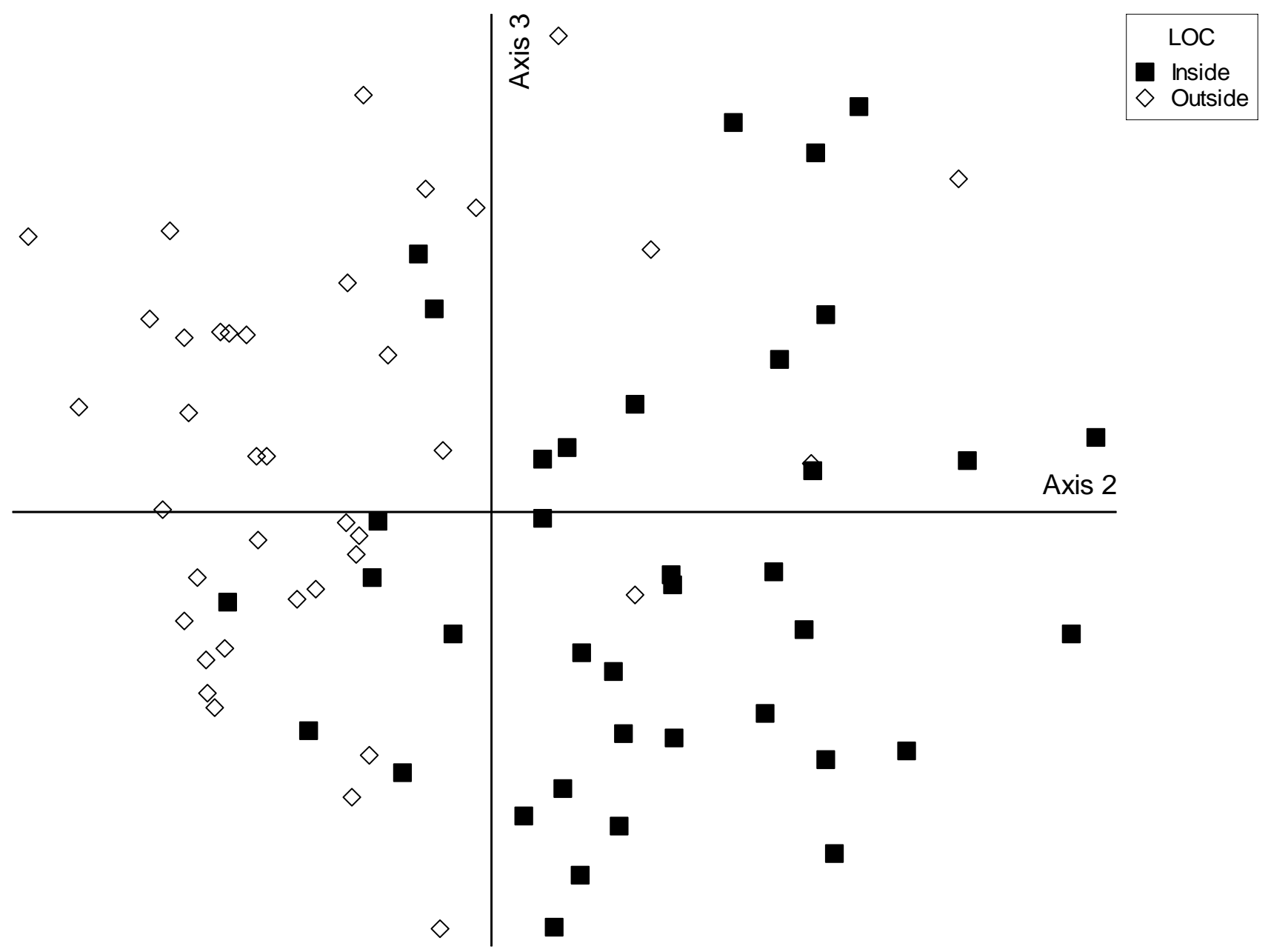

Figure 2. Non-metric multi-dimensional scaling (NMS) ordination graph showing the two most explanatory axes of ponds surveyed in Canaan Valley, West Virginia, USA in 2004-2005. Black squares (inside) indicate communities inside the influence of the impoundment. Hollow diamonds (outside) represent communities outside of this influence. Community data includes herbaceous species and cover variables. 


\title{
CHAPTER III
}

\section{MAPPING HABITAT SUITABILITY FOR BEAVER (CASTOR CANADENSIS) USING GEOGRAPHIC INFORMATION SYSTEMS.}

\author{
Jerri L. Bonner and James T. Anderson ${ }^{1}$ \\ West Virginia University \\ Division of Forestry, Wildlife and Fisheries Resources Program \\ P.O. Box 6125 \\ Morgantown, WV 26506 \\ Email: jander25@wvu.edu \\ ${ }^{1}$ corresponding author
}

Abstract: Beaver (Castor canadensis) alter ecosystems and affect vegetative growth patterns in streams and wetlands throughout most of North America. We produced a habitat suitability model and map using a geographic information system, incorporating multiple layers important to beaver use. The map was applied to the Canaan Valley area of West Virginia, USA. Model results were compared to the published habitat suitability index (HSI) for North American beaver. Validation was performed by comparing active beaver locations to randomly selected locations in the study area. Our mean model value for active sites was significantly greater than that of random points $(P=0.0325)$. Our model values were higher than those of the HSI model, which lacks validation $(P<0.001)$. We believe this type of model is a viable alternative to intensive surveys, with the ability to classify beaver habitat suitability over a large landscape. We show the usefulness of this type of modeling in identifying areas where beaver activity may be important to rare plant conservation decisions. Local information concerning food preferences and habitat use, which vary regionally, should be incorporated into this model when available. This model is presented as a tool for land and wildlife management where beaver populations are a concern.

This manuscript prepared using the format of the journal Wetlands. 
Key Words: Canaan Valley, Castor canadensis, GIS, Habitat Suitability, HSI, Model

\section{INTRODUCTION}

Geographic information systems (GIS) are often used to create predictive habitat maps for management of some species of concern (Gabler et al. 2000). These mapping efforts can be

particularly effective when habitat requirements of the target species are well known (Osborne et al. 2001, Gurnell et al. 2002). Modeling using a GIS-based approach is becoming more frequent and accurate as digital datasets improve. Beaver (Castor canadensis Kuhl) habitat use and quality have been modeled throughout North America using various techniques and measures (Allen 1983, Beier and Barrett 1987, Suzuki and McComb 1998). A GIS-based approach was used by Macdonald et al. (2000) to assess suitable reintroduction sites of European beaver (Castor fiber) in Scotland. However, no GIS-based habitat suitability model has been created for the North American beaver.

The ecosystem alterations created by beaver can have significant impacts on streams and wetlands across much of North America. The dam-building activities of these large rodents alter forest succession by flooding areas (Barnes and Dibble 1988, Naiman et al. 1988), leading to changes in sediment retention, invertebrate communities, vegetative composition, and stream morphology (Naiman et al. 1986, Wright et al. 2002). Herbivory by beavers also can have a dramatic effect on successional trends along streams (Barnes and Dibble 1988, Naiman et al. 1988).

While historical beaver activities were a natural influence on a relatively unaltered landscape, they are now a potential hindrance to typical successional patterns (Balcombe et al. 2005). Fortney and Rentch (2003) named beaver activities as one potential factor in the reduction of some rare plant communities in West Virginia. They cite beaver activity as a 
primary cause of a $>40 \%$ loss in developing coniferous forests. Naiman et al. (1988) indicate the potential for beaver-induced community types, such as fens and wet meadows, to be enduring stages of succession instead of temporary patches. Although beaver impoundments in New York have been described as short term habitats (Wright et al. 2002), some ponds in West Virginia have persisted since 1945 (Bonner 2005, Chapter 2). Naiman et al. (1986) suggest that beaver alterations may affect the local landscape for centuries and that these changes are widespread across the distribution of the species.

The ecological effects of beavers are often beneficial to wetland communities. Beavers increase wetland area by creating new wetlands from upland or riparian areas (Wright et al. 2002). Beaver actively create dams to flood a given area, changing sediment deposition and altering the physical characteristics of the soil and stream (Naiman et al. 1988). Although beaver herbivory alone may not completely change community structure (Donkor and Fryxell 1999), long-term cutting of preferred food types, lodge, and dam materials can significantly alter boreal forest composition (Naiman et al. 1986, Barnes and Dibble 1988). A study in New York cited a substantial increase in landscape level herbaceous species richness due to beaver alterations (Wright et al. 2002). In bogs of the northeastern United States flooding by beaver has caused dramatic shifts in vegetation types and diversity (Mitchell and Niering 1993). Although managed to reduce interference with human activities, beavers are an important ecological presence, with multiple behaviors affecting the floristic communities that share their habitat.

Due to the extensive changes that can occur when beaver inhabit an area, the ability to predict suitable habitat is important as a management tool. Current models for beaver suitability may be effective for local determination of habitat quality but are hard to apply across regions. The beaver habitat suitability index (HSI) is an example of a model useful for evaluating on-site 
suitability (Allen 1983). As this index was developed as both a tool and a resource to build other models, we believe a comparison of our model to this standard is necessary to establish effectiveness. The results of this model development should lend to general, quicker analysis of areas requiring management of beaver or the vegetation they may affect. Our objectives were to (1) produce a generalized, accurate spatial model that can be used on a landscape level, (2) compare predicted suitability with the results of the current HSI for beaver, and (3) discuss how this model affects the plant communities found within our study area and the management implications of these predictions. We present a model using a GIS (ArcMap 9.0) to establish most likely areas of beaver use in an area of the central Appalachian Mountains region.

\section{METHODS}

Study Site

Although extirpated from West Virginia by the 1830s (Bailey 1954), beavers were reintroduced to areas of West Virginia around 1936 (Swank 1949). Beaver habitat modeling efforts focused on Canaan Valley, located in Tucker County, West Virginia, USA. Canaan Valley is an anticline valley at an elevation of $1,006 \mathrm{~m}$. All surveys were conducted in Canaan Valley National Wildlife Refuge (Figure 1). The 6,169 ha refuge was established in 1994 and now contains much of the wetland areas in the central and northern portions of the valley. The Blackwater River runs through much of the refuge and is fed by several drainages along its path. Beaver activity is centered in several of these smaller drainages.

The floor of Canaan Valley now contains one of the largest freshwater wetland complexes in the eastern United States. Over 50 rare plant species have been identified within the valley, as well as 35 rare plant communities. Much of the floristic diversity in the area may 
be attributed to the wetland habitats available. Additionally, many northern species occur at the southernmost periphery of their ranges in this area (Fortney 1993).

The valley floor was once a red spruce-hemlock (Picea rubens-Tsuga canadensis) forest, more productive than other forests of its kind in West Virginia (Brooks 1957). The forests were logged, opening the canopy, drying the soils, and leading to extensive fires. Other land use changes, such as attempts at agricultural practices, also have changed the vegetative composition of the valley. Plant communities such as the red spruce forests are still present in Canaan Valley, but the abundance has been greatly reduced. Although some communities were suggested to be slowly returning to this valley (Brooks 1957), Fortney and Rentch (2003) suggested beaver presence as one factor leading to the decreased abundance of several rare plant communities in the valley since 1975 .

Suitability model

This model consists of multiple raster layers, combined to display areas of suitable beaver habitat. The layers involved were those found most significant in previous beaver research and modeling efforts: stream gradient (Howard and Larson 1985, Suzuki and McComb 1998), land distance/available water (Bradt 1938, Brenner 1962), and available woody vegetation (Howard and Larson 1985, Barnes and Mallik 1997). All layers used the same scale, with the least suitability receiving the lowest scores (1) and the highest suitability receiving the highest value (9). Values were determined based on previous modeling efforts and research concerning beaver habitat requirements. The resulting suitability map includes landscape-level determinations of habitat suitability levels. 
The first raster of this model is based on food availability and preferences (Figure 2). The national wetlands inventory (NWI) shapefile and a streams layer were cropped to the Canaan Valley area. Both files were created at a 1:24,000 scale. Each layer received a $200 \mathrm{~m}$ buffer. This distance is the furthest beavers are observed foraging from their water cover (Bradt 1938). The buffered layers were combined using the union function, resulting in the suitable area for beaver activity. A polygon layer of tree species was then created to represent available food sources. This shapefile was cropped using the previously created layer, to remove areas that were not within the specified suitable area. These polygons were ranked based on dominant woody species. Polygons known to be stands of trembling aspen (Populus tremuloides) received higher values, as a preferred food species (Allen 1983, Brenner 1962). Conifer polygons received the lowest scores, as conifers are named as a low quality food item (Brenner 1962). Cover layers for some preferred species, including willow (Salix spp.), were not available for incorporation into this layer, due to occurring more often as individuals or in mixed populations rather than stands. The file was then converted to a raster layer.

The second layer considers the reduced activity of beavers with increasing land distance (Jenkins 1980, Allen 1983; Figure 3). A stream layer was combined with the NWI shapefile to represent areas of suitable water cover. A distance function was then created, extending to 210 $\mathrm{m}$ beyond the edges of the water. The distance function layer was reclassified based on literature values for beaver cutting and foraging distances. Areas of water cover and land within $50 \mathrm{~m}$ were given the highest scores, as those are areas of higher activity (Jenkins 1980, Allen 1983); more distant areas received lower scores, as activity decreases dramatically but can extend to near 200 m (Bradt 1938; Table 1). 
A final layer represents the suitability levels of streams based on gradient. This layer required a digital elevation model (DEM) and a streams layer (Figure 4). The zonal statistics function was used to calculate the range of elevation change for each unique stream segment. Gradient was then calculated as a percentage. Scores were assigned in a new table field, with lower gradients receiving higher scores (Table 1). Scores were based on published stream gradient values suitable for beaver use (Johnson 1952, Allen 1983, Beier and Barrett 1987). The streams layer was converted to a raster file based on assigned scores, then expanded $(60 \mathrm{~m})$ to represent the suitable habitat that can potentially be created in wide valleys when damming and subsequent flooding occurs (Allen 1983).

All raster layers were combined after weighting individual layers (Figure 5). Most beaver surveys and habitat models have shown a strong relation between stream gradient and beaver presence (Allen 1983, Beier and Barrett 1987). Due to this association, gradient was weighted highest in the model. Vegetation polygons received low weight in this model, as food availability has previously been found to add little explanatory weight to beaver habitat modeling (Beier and Barrett 1987). As a descriptive means of showing the use of this model as a management tool, we overlaid a layer of rare plant species points (Figure 6) using known locations from various recent surveys (Appendix 5). Zonal statistics were used to find the mean GIS model value for each rare plant location.

Validation of the model was conducted by locating areas of current beaver activity in the study area and random points within the overall suitable habitat. Active beaver locations were determined from field observations of beavers or new beaver activity. Random locations were chosen from wetland centroids using Microsoft Excel. Model values for each type of point were determined using the program ArcMap. Mean suitability values of active beaver areas were 
compared to mean values of randomly selected points using a paired $t$-test with a 0.05 alpha level.

Habitat Suitability Index Comparison

Vegetation characteristics were recorded at randomly selected locations identified as suitable habitat (Figure 7). Factors indicated in the HSI included woody vegetation composition and water level stability (Allen 1983). Values in the index range from 0 to 1 . Average annual water fluctuation was low in the study area, and only surveyed areas with no visible surface area were given a value of zero.

Woody vegetation values were divided into three sections: wetland, adjacent upland within $100 \mathrm{~m}$, and upland area from $100 \mathrm{~m}$ to $200 \mathrm{~m}$ distant. After navigating to each selected location, transects were run through wetland habitat and adjacent upland area in a direction perpendicular to the direction of water flow. Each transect measured the distance from the point to the wetland boundary, in addition to $200 \mathrm{~m}$ of upland habitat. When there was no upland habitat within distances suitable for beaver use, a $100 \mathrm{~m}$ transect was used to measure only wetland area characteristics, with upland sections receiving values of zero. Habitat characteristics were recorded based on the recommendations of the beaver habitat suitability index for wetland cover types (Allen 1983). Vegetative measurements included shrub canopy height, percent tree and shrub crown closures, percent of trees in a specified size range (2.5-15.2 cm diameter breast height), and dominant type of woody vegetation. Shrub canopy height was measured every $10 \mathrm{~m}$ along the transect using a tape measure. Shrub and tree canopy closure were measured using a point intercept method measured every $10 \mathrm{~m}$ along the transect. Tree size classes were measured in $10 \times 10 \mathrm{~m}$ plots every $50 \mathrm{~m}$ along the transect. Dominant woody 
vegetation was determined by using a line intercept method along $25 \mathrm{~m}$ of each section of the transect. Plant species were identified using Strausbaugh and Core (1977), and nomenclature was standardized according to Kartesz (1999).

Values for HSI points were calculated using formulas specified for winter food categories in the model (see Allen 1983). Resulting suitability values of surveyed areas were compared to the suitability predicted by the GIS-based model using paired student's $t$-tests. Alpha values for these tests were 0.05 . Comparisons were made based on model values for both individual points and $200 \mathrm{~m}$ areas surrounding those points (Table 2). Buffered values were calculated using the neighborhood statistics function in the Spatial Analyst extension in ArcMap 9.0. Statistics were calculated based on 200 map units (meters).

\section{RESULTS}

Our comparison of active beaver locations and random points shows validity in our model. The mean GIS model value for active beaver sites was significantly higher than random points in our study area $\left(t_{13}=2.39, P=0.033\right.$, Figure 8$)$. This test indicates our GIS model predicts beaver occurrence better than chance alone, giving this model validation. Consequently, the analysis of rare plant species in relation to this GIS model shows highest model values, or highest likelihood of beaver activities, in areas where balsam fir (Abies balsamea) and thread rush (Juncus filiformis) occur (Table 3).

A two-tailed $t$-test comparing mean GIS model values to HSI values also shows significantly higher values $\left(t_{25}=-4.39, P<0.001\right)$ in our model (Figure 9). Given that this HSI has not been validated, we believe this gives reason to question its applicability in Canaan Valley and similar areas. However, the same analysis comparing mean model values within a $200 \mathrm{~m}$ radius to HSI values shows no significant difference between models $\left(t_{25}=0.41, P=0.683\right.$, 
Figure 9). Although similar in this respect, our model was not intended to be used and was not validated at this buffered level. This comparison shows the reduced effectiveness of a model that too strongly incorporates areas of unlikely use.

\section{DISCUSSION}

Several models exist to predict areas of suitable beaver habitat, suitable reintroduction areas, or likely dam establishment sites (Allen 1983, Beier and Barrett 1987, Barnes and Mallik 1997, Suzuki and McComb 1998). Models of this nature are particularly useful for both management of beaver populations and conservation of vegetative communities. In our study area, the high occurrence of rare plant species and their possible sensitivity to flooding and herbivory necessitate a method of predicting areas with the greatest suitability for beaver activity. However, the capability of beaver to alter forest succession or change vegetative species composition of large patches has been documented regularly in a variety of habitats and regions (Neff 1957, Naiman et al. 1986, Barnes and Dibble 1988, Mitchell and Niering 1993, Wright et al. 2002). Although the habitat changes created by beavers are a natural occurrence in North America (Naiman et al. 1988), they can be extensive and detrimental to commercial and agricultural land use (Wigley and Garner 1986).

Creating a GIS-based model allows landscape-level coverage with minimal field collection. In contrast, models such as the HSI have the potential to be more applicable on a persite basis. However, our model gave higher suitability values than the HSI model. We believe this is an indication of higher accuracy in our model in general. A comparison of our model, with average values within a $200 \mathrm{~m}$ radius, to HSI values shows similar means for both models. We believe that this indicates a reduction in model effectiveness due to incorporation of unlikely areas of beaver use. Although foraging activity has been documented up to $200 \mathrm{~m}$ from water 
cover (Allen 1983), most activity is found within $30 \mathrm{~m}$ and is not unusual up to $100 \mathrm{~m}$ from water (Bradt 1938). Additionally, no sign of beaver foraging was observed more than $100 \mathrm{~m}$ from water during our vegetation surveys. Consequently, we believe our model is more effective when used with base values or with a buffer of $\leq 100 \mathrm{~m}$. Although the HSI may not lack in usefulness in identification of important habitat characteristics, it heavily relies on woody vegetation variables to define suitability of habitat. Multiple studies have stressed the importance of physical factors, rather than vegetative factors, in determining beaver habitat (Jenkins 1980, Howard and Larson 1985). These observations were incorporated into our efforts, which resulted in a more valid model.

In application of this model to our study area, there appears to be a high model value for areas of long-term beaver use, particularly the larger ponds on refuge lands. Concurrent studies have indicated a trend of higher rare plant abundance in older beaver impoundments (Bonner 2005, Chapter 2). As highly suitable habitat, these areas would remain active, or be among the first to be inhabited by beaver, if a population decline occurred due to natural causes or trapping activities. Alternately, new beaver ponds may be a less suitable habitat for beaver, support fewer rare plants, and submerge additional flood-intolerant species. Although ponds may be short-term and abandoned quickly, long-term flooding will change the vegetative community in a localized area (Wright et al. 2002). This could have negative effects for particular rare plant species of concern, such as red spruce (Picea rubens), which is intolerant of long-term flooding. We suggest limited and highly regulated beaver trapping would not negatively affect rare plant habitat while potentially conserving currently un-altered areas. Moreover, deterrence methods could be used in areas of concern that are identified as suitable habitat by our model but are not conducive to trapping. 
The widespread availability of spatial datasets makes a more accurate, predictive map possible. Aerial photography has long been cited as a method of identifying beaver inhabited areas (Dickinson 1971), but GIS modeling based on landscape features allows for more defined, precise calculations of beaver habitats than photographic documentation alone. Moreover, we show a simple analysis of rare plant species locations that can aid in conservation and beaver population management decisions. Analyses involving plant abundance or population extent, whenever available, can further enable managers to analyze the potential of beaver disturbance on rare plant communities.

\section{Management Implications}

Beaver habitat preferences are highly based on physical features that can be easily mapped. This model allows managers the opportunity to spatially reference areas that are likely to be affected by beaver activity. This model is particularly advantageous given the minimal amount of effort required in data collection, in comparison with more intensive vegetation surveys required for models such as the HSI. This habitat mapping should be applied toward conservation of vegetative communities, particularly those intolerant of sustained flooding events that are commonly associated with beaver. The model also may allow for the determination of high populations of beaver. Beaver activity in low value areas may suggest that all high quality areas are either exhausted or currently inhabited. These indicators should be useful to land managers if developing a management plan for beaver populations or the vegetative communities which they may affect.

We suggest this model could be used as a tool in similar areas, particularly the northeastern United States. However, food preferences for all local areas should be taken into 
account. Additionally, there are some limitations inherent in GIS use. Particularly, the accuracy and availability of these types of data are not equal for all areas. This model should improve as NWI and vegetation/community cover layers are updated and become more accurate. Moreover, the woody food layer could be more precise when additional preferred foods, such as aspen and willow, can be identified and given applicable scores. Although aerial photographs show some beaver impoundments that are not ranked highest by the model, the alterations caused by beavers in the past can alter the flow of stream systems, thereby affecting the accuracy of any stream layer. In mountainous areas, such as our study area, the steep hillsides bordering water cover may limit the spatial extent of beaver use. Useful analysis of this factor and incorporation into the model may require more precise digital elevation models. The continual improvement in GIS is critical to this type of application. The most recent, most accurate layers should always be incorporated into modeling efforts when available.

\section{ACKNOWLEDGMENTS}

Funding and logistical support for this project was provided by the Canaan Valley Institute, the Cooperative State Research, Education, and Extension Service, the Regional Research Institute of West Virginia University, and the West Virginia University Division of Forestry. Special thanks to Dr. Michael Strager for GIS and modeling advice. We thank Dr. John Edwards and Mr. William N. Grafton for review of this manuscript. We thank Dr. George Seidel for statistical guidance. We thank Canaan Valley National Wildlife Refuge for access to our study sites and support of this research. This is scientific article number xxxx of the West Virginia University Agricultural and Forestry Experiment Station. 


\section{LITERATURE CITED}

Allen, A. W. 1983. Habitat suitability index models: Beaver. U.S. Fish and Wildlife Service. FWS/OBS-82/10.30 Revised. 20pp.

Bailey, R. W. 1954. Status of beaver in West Virginia. Journal of Wildlife Management 18:184190.

Balcombe, C. K., J. T. Anderson, R. H. Fortney, J. S. Rentch, W. N. Grafton, and W. S. Kordek. 2005. A comparison of plant communities in mitigation and reference wetlands in the mid-Appalachians. Wetlands 25:130-142.

Barnes, W. J. and E. Dibble. 1988. The effects of beaver in riverbank forest succession. Canadian Journal of Botany 66:40-44.

Barnes, D. M. and A. U. Mallik. 1997. Habitat factors influencing beaver dam establishment in a northern Ontario watershed. Journal of Wildlife Management 61:1371-1377.

Beier, P. and R. H. Barrett. 1987. Beaver habitat use and impact in the Truckee River Basin, California. Journal of Wildlife Management 51:794-799.

Bonner, J. L. 2005. The influence of beaver impoundments on vegetative composition, and modeling habitat suitability as a tool for wildlife management and conservation. M. S. Thesis, West Virginia University, Morgantown, WV, USA.

Bradt, G. W. 1938. A study of beaver colonies in Michigan. Journal of Mammalogy 19:139162.

Brenner, F. J. 1962. Food consumed by beavers in Crawford County, Pennsylvania. Journal of Wildlife Management 26:104-107.

Brooks, M. 1957. Canaan Valley. West Virginia Conservation 21:7-10. 
Dickinson, N. R. 1971. Aerial photographs as an aid in beaver management. New York Fish and Game Journal 18:57-61.

Donkor, N. T. and J. M. Fryxell. 1999. Impact of beaver foraging on structure of lowland boreal forests of Algonquin Provincial Park, Ontario. Forest Ecology and Management 118:8392.

Fortney, R. H. 1993. Canaan Valley - An area of special interest within the upland forest region. In S. L. Stephenson (ed.) Upland Forests of West Virginia. McClain Printing Co., Parsons, West Virginia, USA.

Fortney, R. H. and J. S. Rentch. 2003. Post logging era plant successional trends and geospatial vegetation patterns in Canaan Valley, West Virginia, 1945 to 2000. Castanea 68:317334.

Gabler, K. I., J. W. Laundré, and L.T. Heady. 2000. Predicting the suitability of habitat in southeast Idaho for pygmy rabbits. Journal of Wildlife Management 64:759-764.

Gurnell, J., M. J. Clark, P. W. W. Lurz, M. D. F. Shirley, S. P. Rushton. 2002. Conserving red squirrels (Sciurus vulgaris): mapping and forecasting habitat suitability using a Geographic Information Systems approach. Biological Conservation 105:53-64.

Howard, R. J. and J. S. Larson. 1985. A stream habitat classification system for beaver. Journal of Wildlife Management 49:19-25.

Jenkins, S. H. 1980. A size-distance relation in food selection by beavers. Ecology 61:740-746. Johnson, F. M. 1952. 1952 Beaver Survey, West Virginia. West Virginia Conservation 16:36-37. Kartesz, J. T. 1999. A synonymized checklist and atlas with biological attributes for the vascular flora of the United States, Canada, and Greenland, first edition. In J. T. Kartesz, and C. 
A. Meachum (eds.) Synthesis of the North American Flora, Version 1.0. North Carolina Botanical Garden, University of North Carolina, Chapel Hill, NC, USA.

Macdonald, D. W., F. H. Tattersall, S. Rushton, A. B. South, S. Rao, P. Maitland, and R. Strachan. 2000. Reintroducing the beaver (Castor fiber) to Scotland: a protocol for identifying and assessing suitable release sites. Animal Conservation 3:125-133.

Mitchell, C. C. and W. A. Niering. 1993. Vegetation change in a topogenic bog following beaver flooding. Bulletin of the Torrey Botanical Club 120:136-147.

Naiman, R. J., J. M. Melillo, and J. E. Hobbie. 1986. Ecosystem alteration of boreal forest streams by beaver (Castor canadensis). Ecology 67:1254-1269.

Naiman, R. J., C. A. Johnston, and J. C. Kelley. 1988. Alteration of North American streams by beaver. BioScience 38:753-762.

Neff, D. J. 1957. Ecological effects of beaver habitat abandonment in the Colorado Rockies. Journal of Wildlife Management 21:80-84.

Osborne, P. E., J. C. Alonso, and R. G. Bryant. 2001. Modeling landscape-scale habitat use using GIS and remote sensing: a case study with great bustards. Journal of Applied Ecology $38: 458-471$.

Strausbaugh, P. D., and E. L. Core. 1977. Flora of West Virginia. Seneca Books, Inc., Morgantown, WV, USA.

Suzuki, N. and W. C. McComb. 1998. Habitat classification models for beaver (Castor canadensis) in the streams of the central Oregon coast range. Northwest Science 72:102-110.

Swank, W. G. 1949. Beaver ecology and management in West Virginia. Conservation Commission of West Virginia, Division of Game Management, Bulletin No. 1. 
U.S. Fish and Wildlife Service. 1996. National list of vascular plant species that occur in Wetlands: 1996 national summary. U.S. Fish and Wildlife Service, Washington DC, USA.

Wigley, T. B. and M. E. Garner. 1986. Landowner-reported beaver damage in the Arkansas delta. Proceedings of the Annual Conference of the Southeaster Association of Fish and Wildlife Agencies 40:476-482.

Wright, J. P., C. G. Jones, and A. S. Flecker. 2002. An ecosystem engineer, the beaver, increases species richness at the landscape scale. Oecologia 132:96-101. 
Table 1. Layers used in the geographic information system (GIS) model to characterize beaver habitat suitability. Values for each category range from 0 (unsuitable) to 9 (highly suitable). Weight represents importance for suitable beaver habitat, highest value represent highest importance in model. Weights and values were derived from relevant literature, including Brooks (1957), Allen (1983), Barnes and Mallik (1997), and Suzuki and McComb (1998).

\begin{tabular}{|c|c|c|c|}
\hline Layer & Weight & Category & Value \\
\hline \multirow[t]{5}{*}{ Food resources } & 0.15 & & \\
\hline & & Conifer & 1 \\
\hline & & Hardwood & 5 \\
\hline & & Aspen & 9 \\
\hline & & None & 0 \\
\hline \multirow[t]{5}{*}{ Distance } & 0.35 & & \\
\hline & & $<50 \mathrm{~m}$ & 9 \\
\hline & & $50-<100 \mathrm{~m}$ & 5 \\
\hline & & $100-210 \mathrm{~m}$ & 1 \\
\hline & & $>210$ & 0 \\
\hline \multirow[t]{7}{*}{ Stream Gradient } & 0.50 & & \\
\hline & & $<2 \%$ & 9 \\
\hline & & $2-<4 \%$ & 7 \\
\hline & & $4-<8 \%$ & 5 \\
\hline & & $8-<12 \%$ & 3 \\
\hline & & $12-20 \%$ & 1 \\
\hline & & $>20 \%$ & 0 \\
\hline
\end{tabular}


Table 2. Values are given for each model at each of 26 survey locations in Canaan Valley, WV, USA in summer 2005. Habitat suitability index (HSI) value indicates calculated value using formulas described by Allen (1983). Model point values are the geographic information systems (GIS) model values for each location. Buffered GIS values are mean value of the area within a $200 \mathrm{~m}$ radius from each point. Latitude and longitude are calculated in North American Datum 1983.

\begin{tabular}{|c|c|c|c|c|c|}
\hline Location & HSI & GIS & Buffered GIS & $\begin{array}{r}\text { Latitude } \\
\text { (UTM) }\end{array}$ & $\begin{array}{r}\text { Longitude } \\
\text { (UTM) }\end{array}$ \\
\hline N Timberline Resort & 0.315 & 0.850 & 0.375 & 639751.93 & 4326114.08 \\
\hline W Sand Run & 0.568 & 0.739 & 0.324 & 639799.08 & 4327280.87 \\
\hline NE Sand & 0.447 & 0.850 & 0.333 & 639977.62 & 4327332.16 \\
\hline S Glade & 0.530 & 0.850 & 0.350 & 640550.88 & 4327824.82 \\
\hline Glade Run & 0.408 & 0.850 & 0.402 & 640793.35 & 4328351.34 \\
\hline Cortland Bridge & 0.366 & 0.850 & 0.523 & 635720.30 & 4325335.57 \\
\hline Bealle Tract & 0.490 & 0.350 & 0.209 & 637060.32 & 4325720.63 \\
\hline CVI & 0.287 & 0.628 & 0.323 & 637220.24 & 4331043.60 \\
\hline $\mathrm{E}$ of CVI & 0.023 & 0.350 & 0.470 & 637759.26 & 4330879.77 \\
\hline S Camp 70 & 0.000 & 0.850 & 0.430 & 638041.91 & 4331812.34 \\
\hline S Camp 70 - NE & 0.000 & 0.194 & 0.412 & 638275.18 & 4331892.25 \\
\hline W Camp 71 & 0.418 & 0.694 & 0.277 & 639164.92 & 4333712.04 \\
\hline NE Camp 71 & 0.554 & 0.850 & 0.386 & 639487.24 & 4333654.40 \\
\hline Camp 71 - Large & 0.000 & 0.850 & 0.459 & 639879.68 & 4333188.84 \\
\hline Camp71 - S Rail & 0.921 & 0.350 & 0.402 & 639060.39 & 4332818.73 \\
\hline Freeland & 0.448 & 0.739 & 0.392 & 636236.68 & 4320845.10 \\
\hline
\end{tabular}


Table 2. continued

\begin{tabular}{lrrcrc}
\hline Location & HSI & GIS & Buffered GIS & $\begin{array}{r}\text { Latitude } \\
\text { (UTM) }\end{array}$ & $\begin{array}{r}\text { Longitude } \\
\text { (UTM) }\end{array}$ \\
\hline S Freeland & 0.774 & 0.739 & 0.224 & 636768.48 & 4320680.39 \\
HQ & 0.173 & 0.350 & 0.396 & 634361.14 & 4322831.56 \\
Timberline/32 & 0.339 & 0.350 & 0.251 & 634762.73 & 4322313.22 \\
N Cortland - Ret & 0.703 & 0.822 & 0.347 & 635204.05 & 4327525.18 \\
N Cortland - Beaver & 0.271 & 0.822 & 0.280 & 635305.45 & 4327619.18 \\
N Timberline & 0.366 & 0.194 & 0.272 & 636665.18 & 4322671.34 \\
N Timberline Pond & 0.077 & 0.628 & 0.410 & 636494.41 & 4322269.74 \\
N Big Cove & 0.216 & 0.850 & 0.405 & 643204.19 & 4336432.27 \\
Mid Big Cove & 0.782 & 0.739 & 0.316 & 643181.21 & 4335902.32 \\
S Big Cove & 0.463 & 0.694 & 0.355 & 643085.17 & 4335726.71 \\
Mean & 0.382 & 0.655 & 0.359 & & \\
\hline
\end{tabular}


Table 3. Rare plant species locations in Canaan Valley, West Virginia, USA were overlaid on a geographic information systems (GIS) habitat suitability model.

\begin{tabular}{|c|c|c|c|c|}
\hline Scientific Name & Common Name & Locations $^{\mathrm{a}}$ & $\mathrm{WIS}^{\mathrm{b}}$ & Score $^{c}$ \\
\hline Abies balsamea & Balsam Fir & 9 & Fac & 4.7000 \\
\hline Carex aestivalis & Summer sedge & 1 & $\mathrm{Fac}$ & 0.0000 \\
\hline Carex atlantica & Howe Sedge & 1 & Fac & 3.1500 \\
\hline Carex bromoides & Brome-like sedge & 2 & $\mathrm{Facw}^{+}$ & 3.1500 \\
\hline Carex canescens & Hoary sedge & 11 & Obl & 2.2591 \\
\hline Carex leptonervia & Finely-nerved Sedge & 1 & Facw & 0.0000 \\
\hline Cuscuta rostrata & Beaked Dodder & 1 & & 7.6500 \\
\hline Dalibarda repens & Star violet & 10 & Fac & 2.5300 \\
\hline Eupatorium pilosum & Vervain thoroughwort & 1 & Facw & 0.0000 \\
\hline Euphorbia purpurea & Glade Spurge & 2 & $\mathrm{Fac}$ & 3.5250 \\
\hline Geum rivale & Purple avens & 2 & Obl & 3.9000 \\
\hline Glyceria grandis & American manna-grass & 4 & Obl & 3.9250 \\
\hline Juncus filiformis & Thread Rush & 1 & Facw & 7.6500 \\
\hline Listera smallii & Kidney-leaf twayblade & 1 & Facw & 3.1500 \\
\hline Lonicera canadensis & American fly-honeysuckle & 1 & Facu & 3.1500 \\
\hline Oenothera pilosella & Evening-Primrose & 1 & $\mathrm{Fac}$ & 0.0000 \\
\hline Pogonia ophioglossoides & Rose pogonia & 1 & Obl & 2.5000 \\
\hline Polemonium vanbruntiae & Jacob's ladder & 10 & Facw & 2.9750 \\
\hline Rhamnus alnifolia & Alder-leaved buckthorn & 2 & Obl & 5.0750 \\
\hline Salix discolor & Glaucous willow & 2 & Facw & 2.5250 \\
\hline
\end{tabular}


Table 3. continued

\begin{tabular}{|c|c|c|c|c|}
\hline Scientific Name & Common Name & Locations $^{\mathrm{a}}$ & $\mathrm{WIS}^{\mathrm{b}}$ & Score $^{c}$ \\
\hline Saxifraga pensylvanica & Swamp Saxifrage & 1 & Obl & 1.7500 \\
\hline Schoenoplectus purshianus & Weakstalk bulrush & 1 & Obl & 3.1500 \\
\hline Scirpus atrocinctus & Black-girdle bulrush & 21 & Facw + & 3.4452 \\
\hline Scirpus microcarpus & Small-fruit bulrush & 10 & Obl & 2.6950 \\
\hline Stachys tenuifolia & Smooth Hedge-Nettle & 1 & $\mathrm{Facw}^{+}$ & 3.1500 \\
\hline Synosma suaveolens & Sweet-scented Indian plantain & 4 & Fac- & 2.1000 \\
\hline Thelypteris simulata & Bog Fern & 1 & Facw & 3.1500 \\
\hline Torreyochloa pallida & Manna-grass & 4 & Obl & 3.0625 \\
\hline Vaccinium oxycoccos & Small cranberry & 3 & Obl & 3.1500 \\
\hline Veronica scutellata & Marsh speedwell & 1 & Obl & 3.1500 \\
\hline Viburnum opulus americanum & Highbush cranberry & 2 & Facw & 2.8250 \\
\hline Viola appalachiensis & Appalachian blue violet & 2 & Facu & 2.4500 \\
\hline Zigadenus leimanthoides & Oceanorus & 2 & Obl & 3.1500 \\
\hline
\end{tabular}

${ }^{a}$ Locations indicate the number of occurrences of each rare plant species.

b Wetland indicator status is shown for each species (U.S. Fish and Wildlife Service 1996). Possible status, in order of decreasing wetland fidelity: obligate (obl), facultative wetland (facw), facultative (fac), facultative upland (facu), and upland (upl).

c Score represents the mean value of beaver habitat for each plant species. Scores range from 0 (unsuitable for beaver) to 9 (highly suitable beaver habitat). 

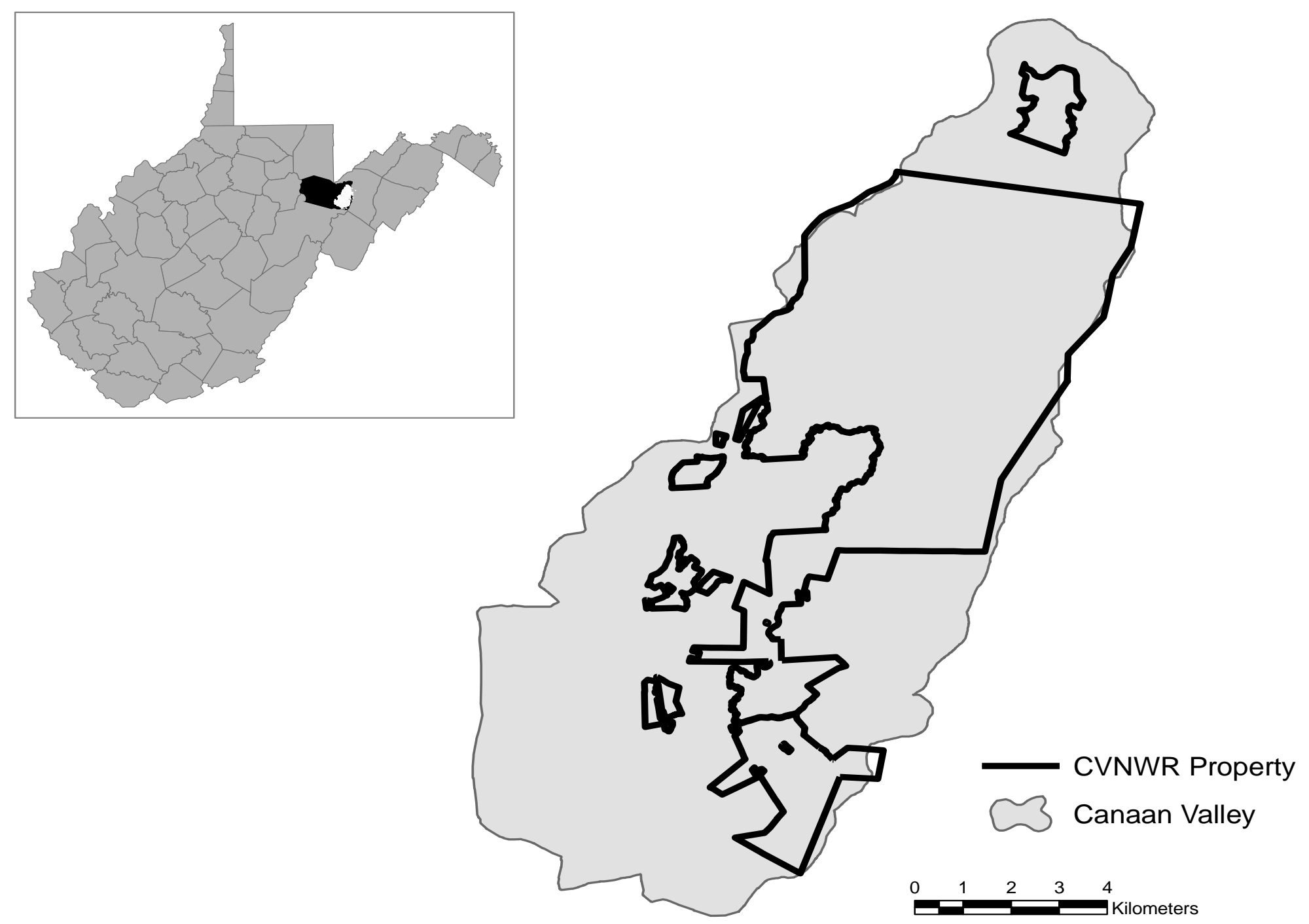

Figure 1. Canaan Valley National Wildlife Refuge (CVNWR) boundaries are shown in black over the gray area of Canaan Valley. Inset shows Canaan Valley located in Tucker County, WV, USA. 


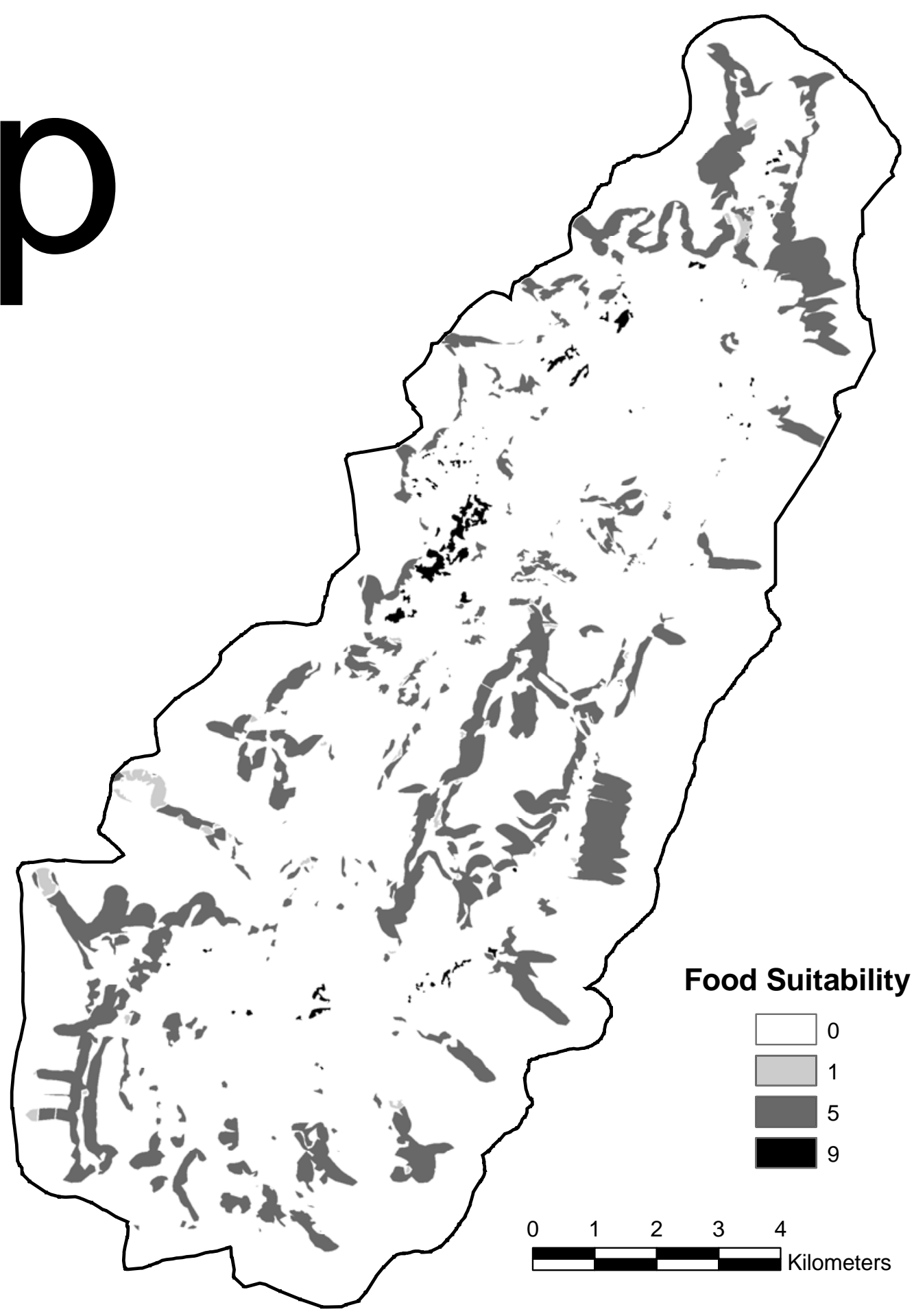

Figure 2. Available woody resources for beaver in Canaan Valley, WV, USA are shown.

Polygons display suitability rankings based on described preferences of certain tree types: no defined tree type (0), conifers (1), hardwoods (5), and quaking aspen (9). 


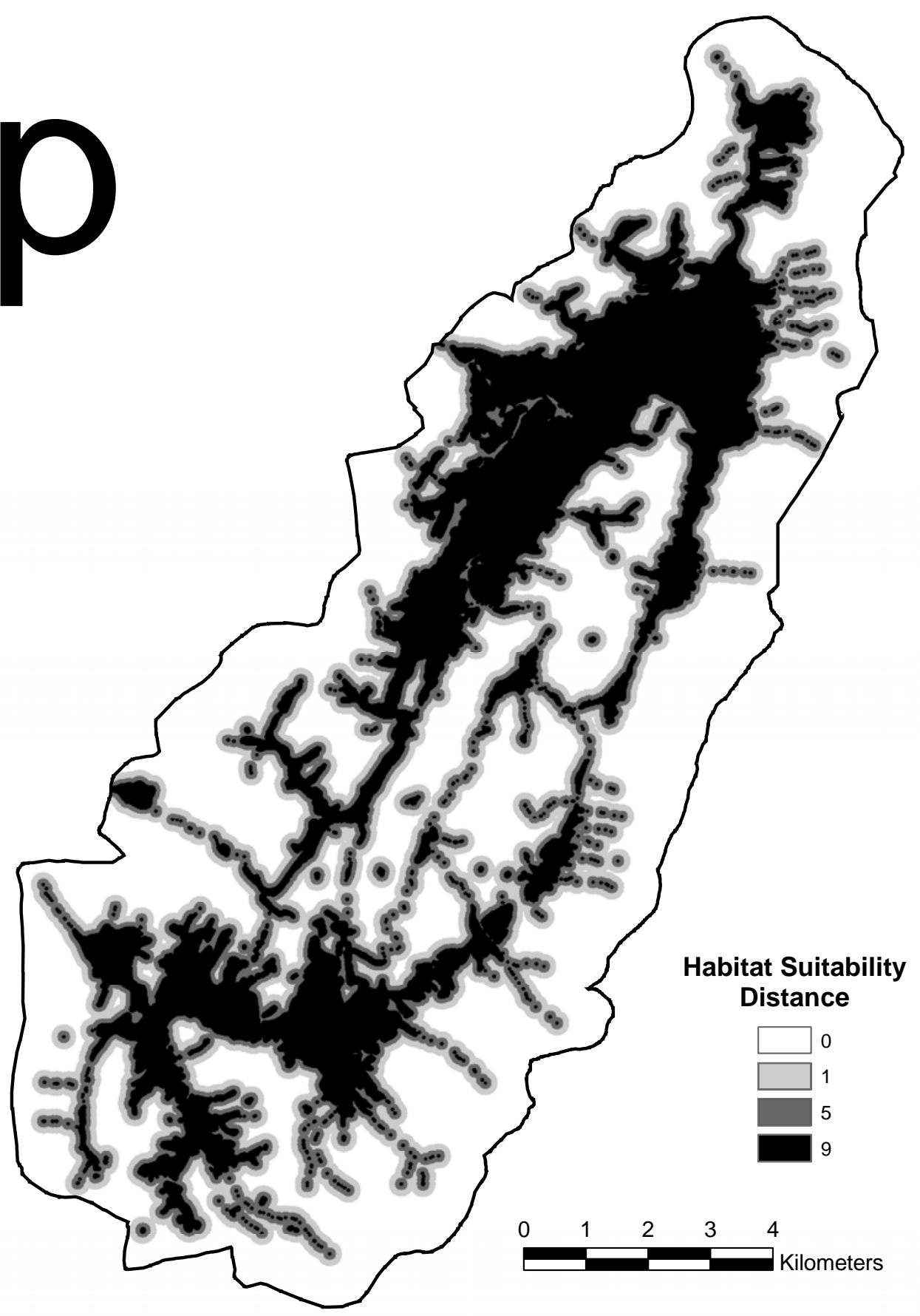

Figure 3. Suitable habitat based on proximity to water in Canaan Valley, WV, USA is displayed. Highest suitability is located in areas of water cover and land in close proximity to water (9) with suitability decreasing as distance to water increases $(5=$ moderately suitable, $1=$ least suitable, 0 $=$ unsuitable). 


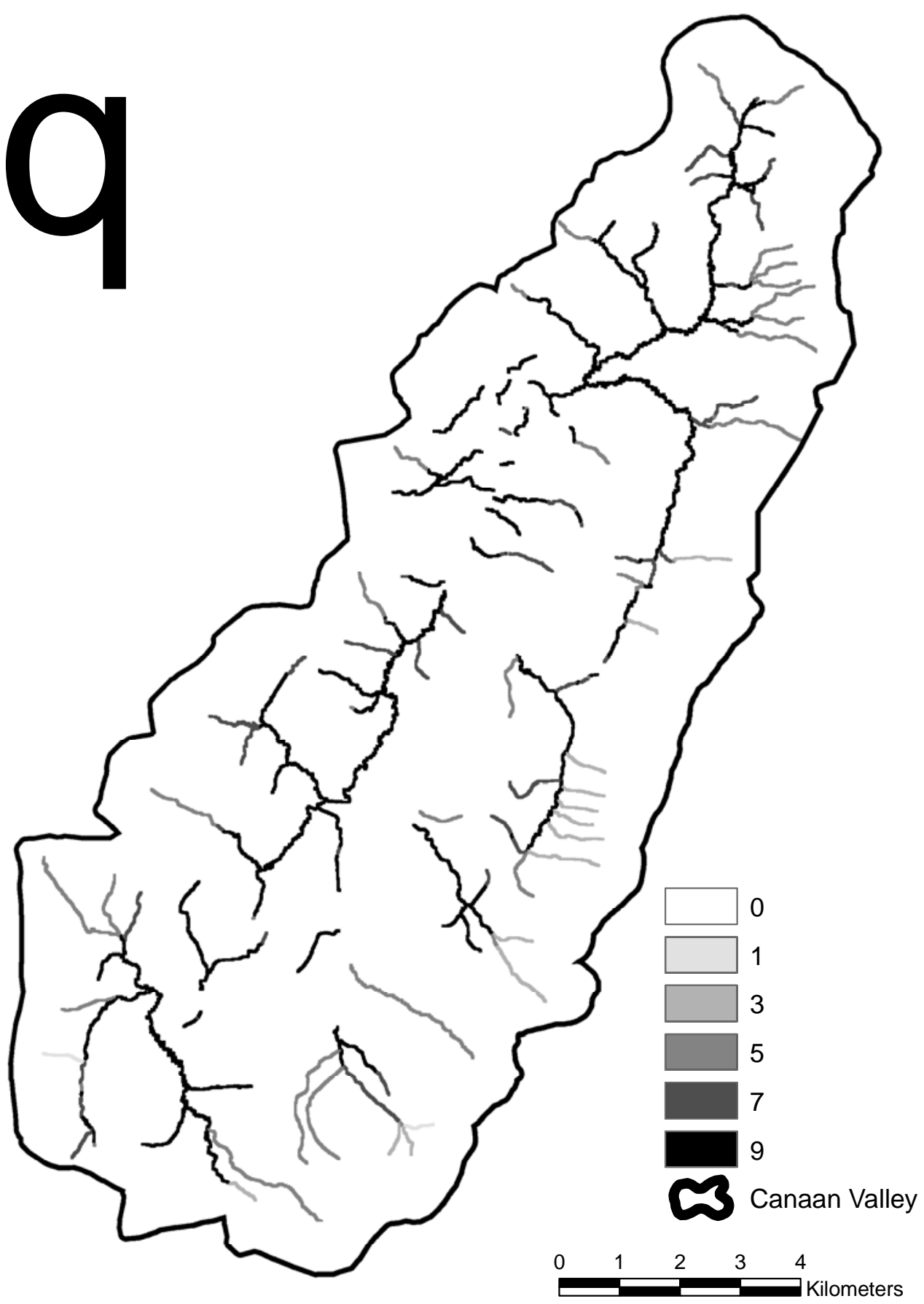

Figure 4. Stream gradient values within Canaan Valley, WV, USA. Streams were not present in unsuitable areas (0). Highly suitable stream gradients (9) are low gradient; suitability decreases with increased gradient $(7=$ more suitable, $5=$ moderately suitable, $3=$ less suitable, $1=$ least suitable). 


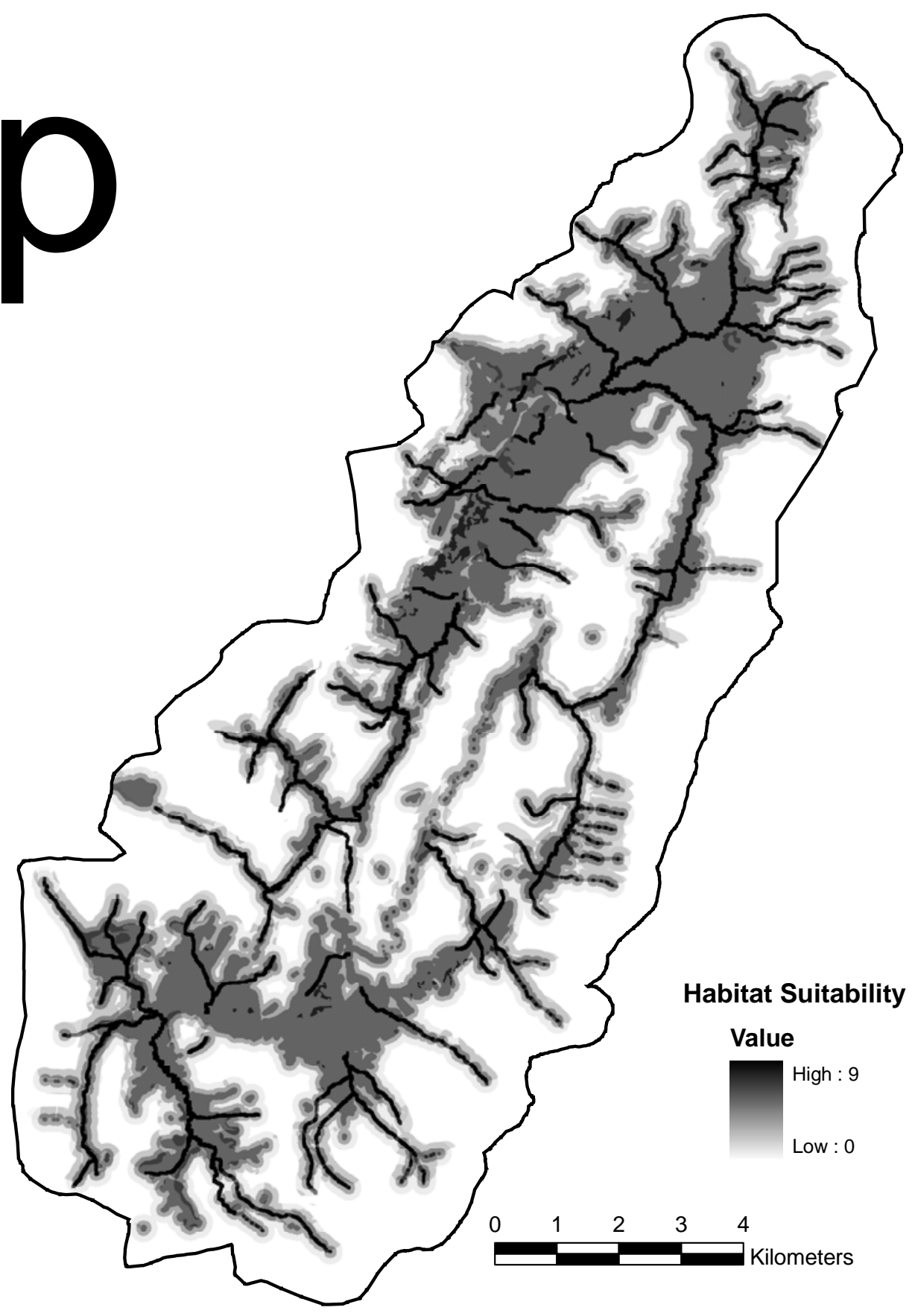

Figure 5. Overall beaver habitat suitability for Canaan Valley, WV, USA was determined by combining stream gradient, vegetation, and distance using a weighted model. Highest suitability is found in areas of low gradients, close proximity to water, and highly preferred food species. A color gradient from black to white shows changes in suitability from most suitable to unsuitable. 


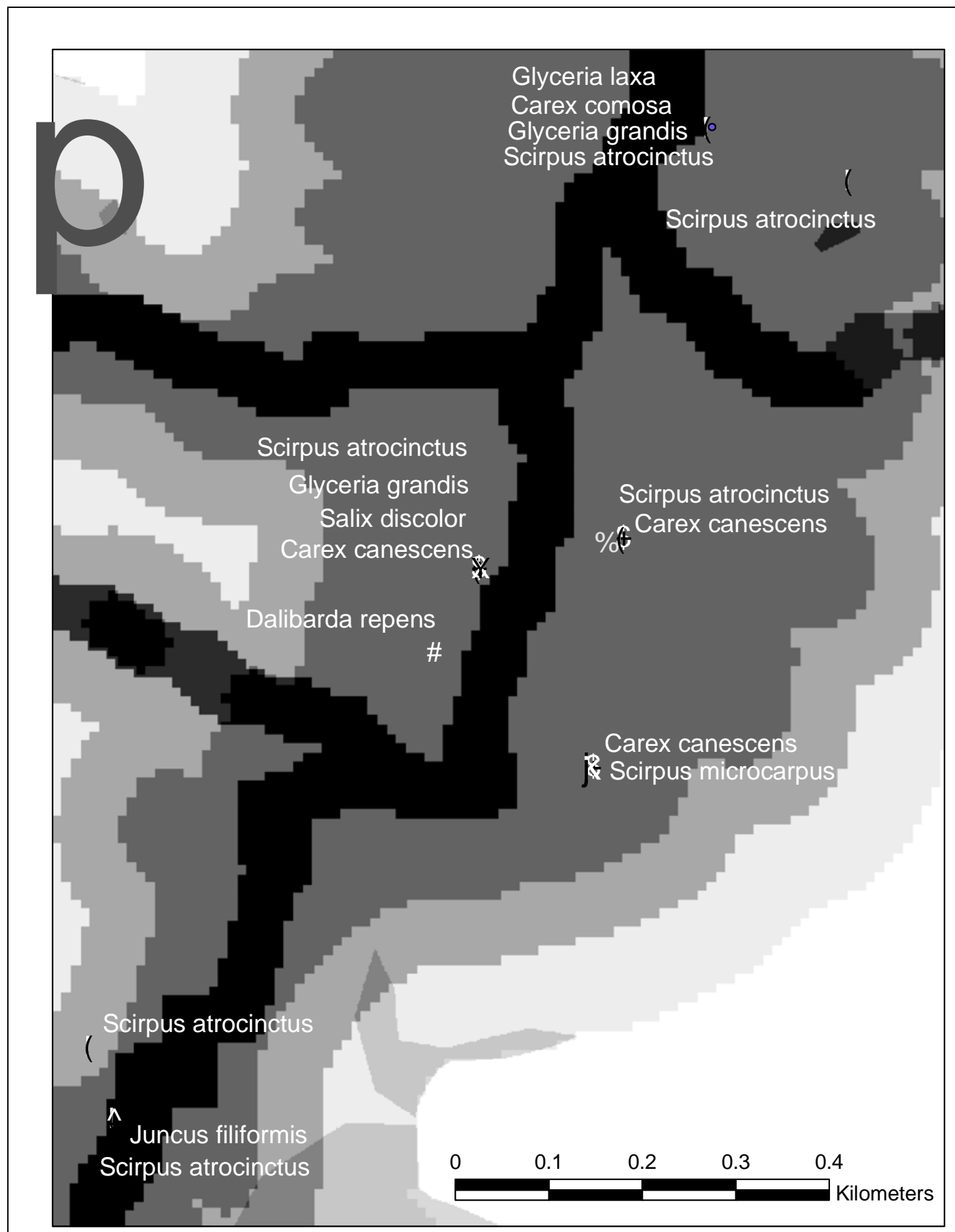

Figure 6. Rare plant species occurring along Glade Run in Canaan Valley, West Virginia, USA.

Rare plant species are shown in relation to geographic information systems (GIS) beaver habitat suitability model. Model values are represented by a gradient from white (lowest suitable habitat) to black (most suitable habitat). 


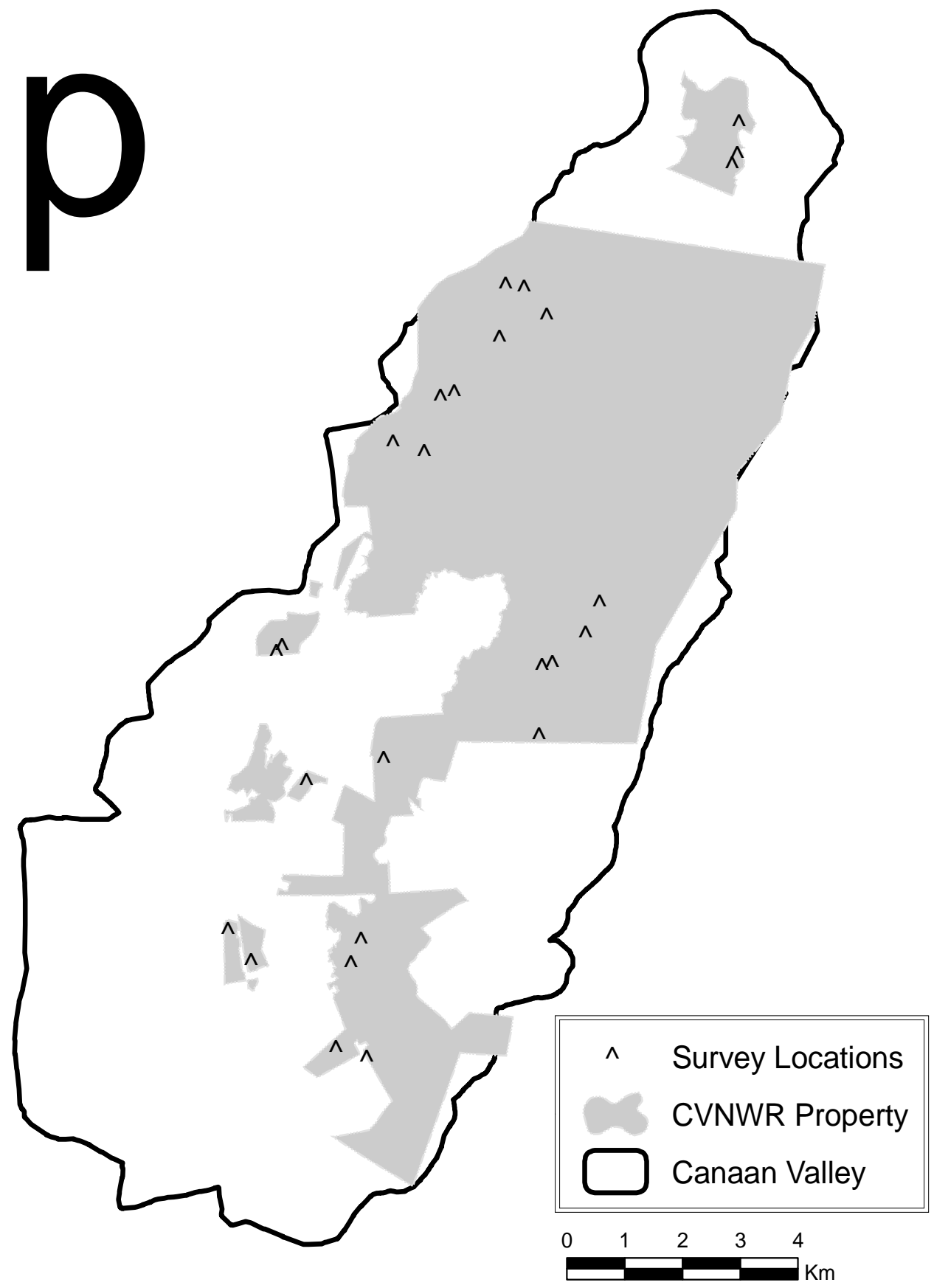

Figure 7. Transect surveys of vegetative characteristics were conducted at 26 random locations throughout Canaan Valley National Wildlife Refuge in Canaan Valley, West Virginia, USA. Grey areas indicate refuge property. Black carets represent survey locations. Black outline shows the ridges surrounding the valley. 


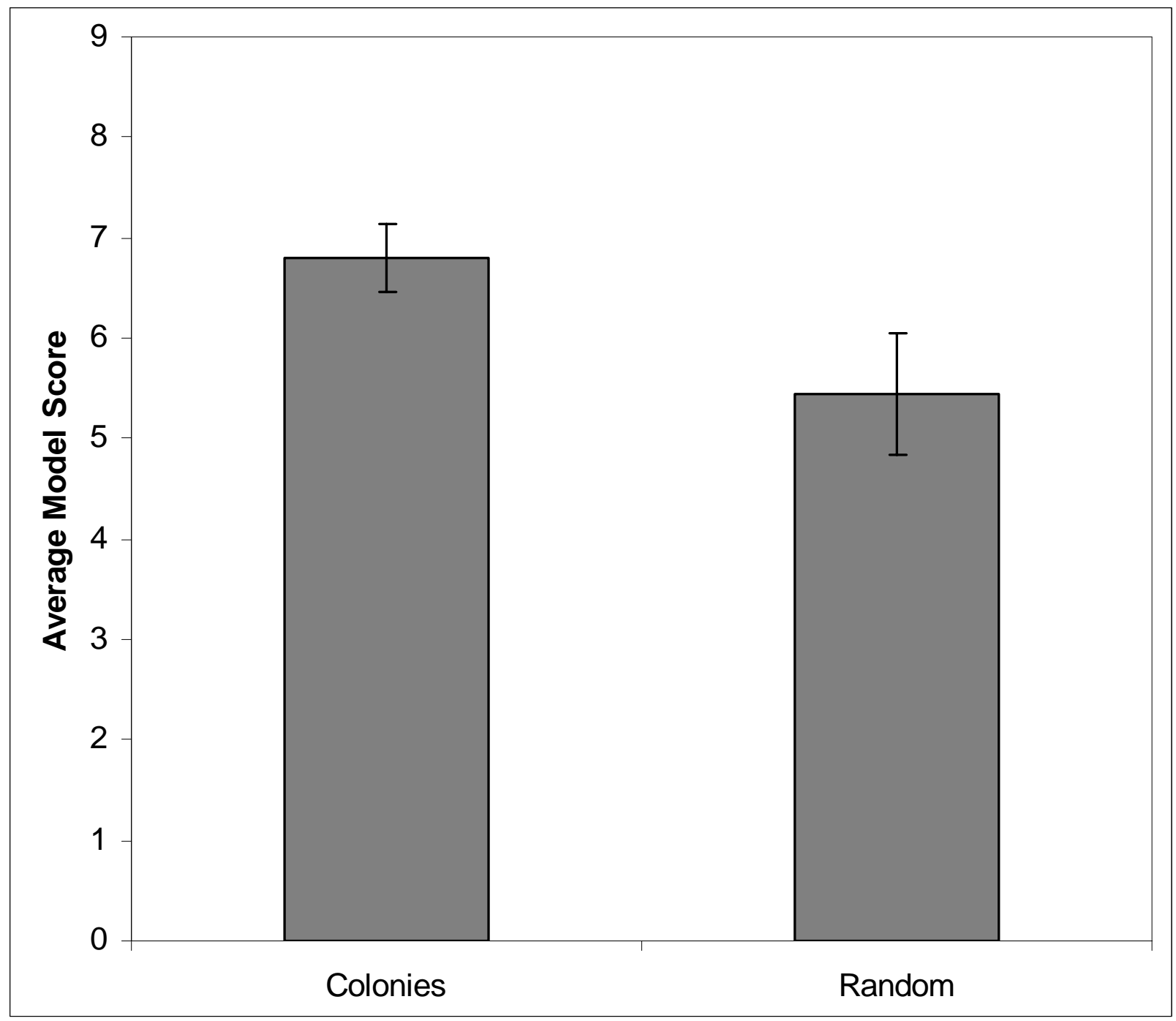

Figure 8. Results of validation of geographic information systems (GIS) model by comparison of active beaver colony sites and randomly selected locations in Canaan Valley, West Virginia, USA. Type is depicted on the x-axis. Mean GIS model score is shown on y-axis. Bars represent standard error. 


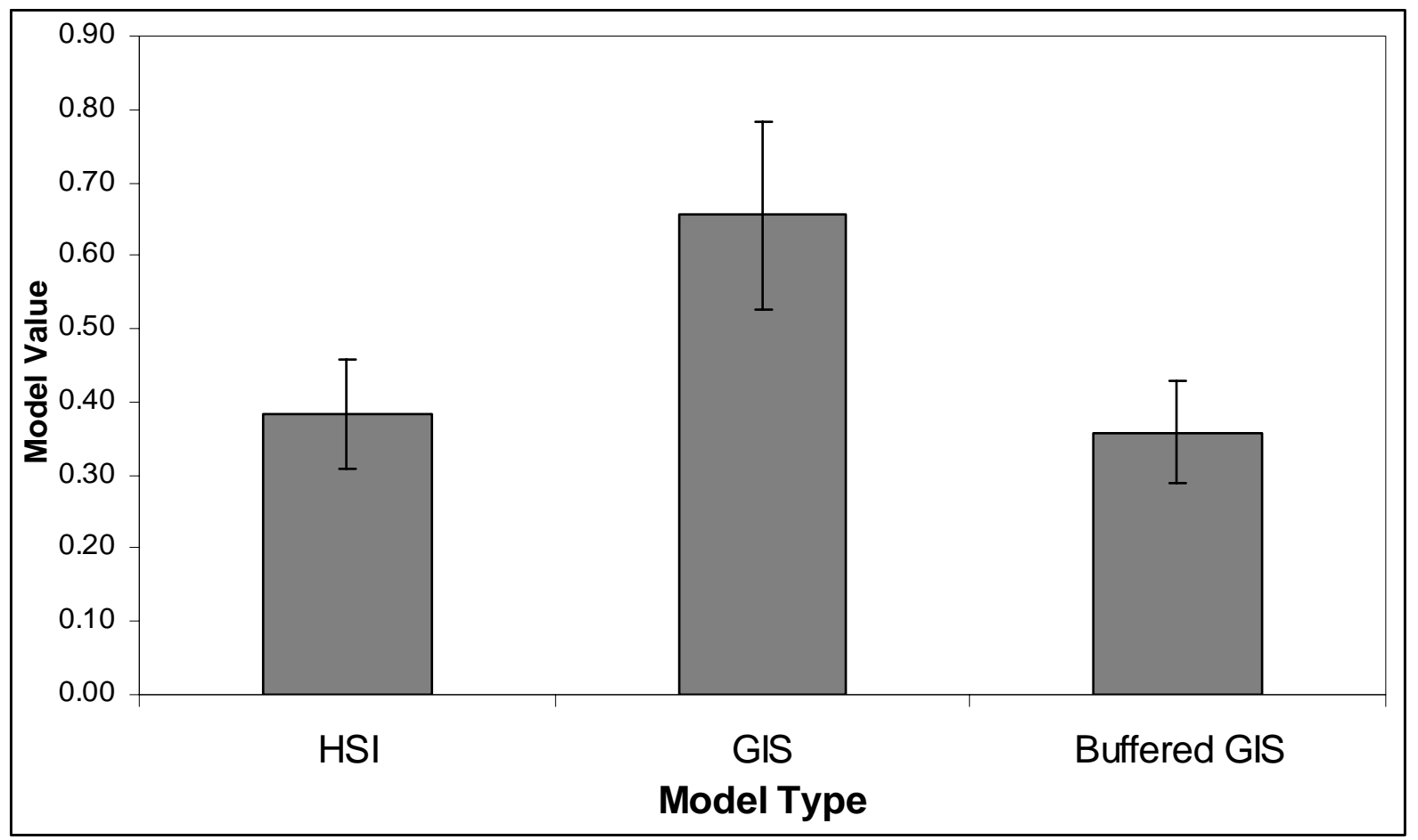

Figure 9. Mean geographic information systems (GIS) model values and habitat suitability index (HSI) values derived from vegetation surveys. Values of HSI are less than GIS values but similar to buffered GIS values. Model type is shown on x-axis: GIS is a single location value; buffered GIS is the mean value of a $200 \mathrm{~m}$ buffer around a point; HSI is the values from survey data. Mean values are shown on y-axis. Bars indicate standard error. 


\title{
Chapter IV
}

\section{Conclusions and management implications for vegetation associated with beaver ponds and}

\section{beaver habitat suitability modeling.}

\author{
Jerri L. Bonner and James T. Anderson \\ West Virginia University \\ Division of Forestry, Wildlife and Fisheries Resources Program \\ Morgantown, WV 26506 \\ Email: autralfamadorian@hotmail.com
}

\begin{abstract}
$\underline{\text { Abstract }}$
Beavers (Castor canadensis Kuhl) can have dramatic effects on vegetative communities through impounding water in small order streams and wetlands. These habitat alterations may be an important influence on rare plant species and communities where beaver ponds are created. We found that the youngest and oldest beaver ponds in Canaan Valley, West Virginia, USA had similar species richness. Rare plant species occurred most in the oldest ponds, although no significant differences were detected. Species composition in pond areas was different between areas influenced by ponds and those not affected by the pond, providing more obligate wetland communities when influenced by beaver. This information should be incorporated into management decisions when conservation of rare plant species is a goal. Our validated geographic information systems (GIS) model can be used to further plan management activities. We believe limited and highly regulated beaver trapping can aid in beaver population reduction without negatively affecting rare wetland plants, while reducing further pond creation in areas where flood-intolerant species may occur. However, a beaver population should be conserved in the area of the oldest ponds to protect and maintain rare plant species.
\end{abstract}




\section{$\underline{\text { Introduction }}$}

Herbivory by beavers can have a dramatic effect on successional trends along streams (Barnes and Dibble 1988). Moreover, the dam-building activities of beavers may alter forest succession through flooding (Barnes and Dibble 1988, Naiman et al. 1988), leading to changes in sediment retention, invertebrate communities, vegetative composition, and stream morphology (Chapter 1). Historically, beaver were a natural influence on a landscape relatively unaltered by man, but now they are a potential hindrance to typical successional patterns (Balcombe et al. 2005). Naiman et al. (1988) document that beaver-induced community types, such as fens and wet meadows, can be enduring stages of succession rather than temporary patches. Although beaver impoundments have been described as short term habitats in New York (Wright et al. 2002), some ponds in West Virginia have persisted since 1945 (Chapter 3). Naiman et al. (1986) suggest that beaver alterations may affect the local landscape for centuries and that these changes are widespread across the distribution of the species.

Although beaver potentially shift successional patterns, the ecological effects of their activities are often beneficial to wetland communities (Chapter 2). Beavers increase wetland area by creating new wetlands from upland or riparian areas. A study in New York cited a substantial increase in landscape level herbaceous species richness due to beaver alterations (Wright et al. 2002). In bogs of the northeastern United States, flooding by beaver has caused dramatic shifts in habitat and vegetative composition (Mitchell and Niering 1993). Although beavers can be considered nuisance wildlife when conflicts with human interests occur, they are an important ecological presence, with behaviors that affect the floristic communities sharing their habitat. 
Management decisions benefit from knowledge of beaver-induced habitat changes, but these decisions can only be improved with the ability to model beaver habitat suitability and predict communities that beaver may affect (Chapter 3). Geographic information systems (GIS) can be used to create predictive habitat maps and models for management of species of concern (Gabler et al. 2000). Mapping efforts can be most effective if habitat requirements of the target species are well known (Chapter 3). Beaver habitat use and quality have been modeled across North America using various statistical applications and habitat variables (Allen 1983, Beier and Barrett 1987, Suzuki and McComb 1990). Current predictive models for beaver may be accurate for local determination of habitat suitability but are hard to apply across landscapes. The beaver habitat suitability index (HSI) (Allen 1983) is one example of a model requiring somewhat intensive local habitat measurements (Chapter 3). Although a GIS-based approach was used by Macdonald et al. (2000) to find the most suitable reintroduction sites for European beaver (Castor fiber) in Scotland, no GIS-based habitat suitability model has been created for the North American beaver. A GIS model should lead to general, quicker analysis of beaver habitat over large areas, supporting management decisions for them or the vegetation they may affect.

Beaver impacts on rare plant communities requires evaluation, considering that in many habitats beaver activities may lead to local declines of certain species (Mitchell and Niering 1993). However, on a landscape level, beaver activity can possibly increase species richness (Wright et al. 2002). These contrasting possibilities are cause for examination, particularly in areas where the floristic communities are rare and may be negatively affected by habitat alterations by beaver (Chapter 2).

The objectives of this project include predicting the most suitable areas of beaver use, then determining which vegetative groups will likely be affected by beaver activity in these areas. 
We hypothesized that older ponds may provide a microhabitat for rare plant species and that these older impoundments would be predicted as highly suitable areas for beaver. The main objectives of our research were to (1) determine if beaver ponds are areas of high vegetative species richness and diversity or havens for rare plant species; (2) examine factors leading to vegetative community structure in areas associated with beaver impoundments; and (3) create and validate a probability map and model incorporating known habitat suitability factors.

\section{$\underline{\text { Study Area and Methods }}$}

Our study took place in Canaan Valley, located in Tucker County, West Virginia, USA. Canaan Valley is an anticline valley at a 1,006 $\mathrm{m}$ elevation. The precipitation during summer months (June-August) averages $36.5 \mathrm{~cm}$ and the average temperature is $17.7^{\circ} \mathrm{C}$ (Southeast Regional Climate Center 1996). During winter the average temperature is $-3.5^{\circ} \mathrm{C}$ (National Climate Data Center 2003), and the freeze-free period lasts an average of 90 days (Beverage 1967). All pond (Chapter 2) and HSI (Chapter 3) vegetation surveys were conducted on Canaan Valley National Wildlife Refuge (CVNWR)(Figure 1), which was established in 1994. Much of the wetlands in the north and central parts of the valley are contained in the 6,169 ha refuge. The Blackwater River runs through much of the refuge and is fed by several drainages where beaver activity is prevalent.

The overall vegetative composition in Canaan Valley may be considered boreal (Fortney 1993). Beaver pond areas are often dominated by herbaceous communities, such as Carex spp. and Juncus effusus, and by scrub-shrub communities, particularly Spiraea alba. Canaan Valley contains the largest freshwater wetland complex in mid-Appalachia. Over 50 rare plant species and 30 rare plant communities have been identified within the valley. The wetland habitats 
available may explain much of the floristic diversity of the area. Additionally, many species with northern distributions occur at the southernmost periphery of their ranges in the valley (Fortney 1993). Coniferous forests comprise several rare plant communities in the area; current loss of developing coniferous forests has been partially attributed to beaver activity (Fortney and Rentch 2003). Although extirpated in the 1850s, beavers were reintroduced to the Canaan Valley area of West Virginia in the 1930s (Swank 1949). Fortney and Rentch (2003) suggested beaver presence as one factor leading to the decreased abundance of several rare plant communities in the valley since 1975 .

We conducted beaver pond vegetation surveys from July-September 2004 and during June 2005 (Chapter 2). This portion of our study inventoried vegetation associated with beaver ponds and surrounding areas, particularly species richness, diversity, and composition. We also created a GIS map and model of beaver habitat suitability, which we applied to Canaan Valley. We compared our results with the beaver habitat suitability index (HSI) values calculated from surveys conducted in July-August 2005 (Chapter 3).

\section{$\underline{\text { Results }}$}

Of 203 species observed, the most abundant around beaver ponds included herbaceous species such as Rubus hispidus and Juncus effusus and the shrub species Spiraea alba. We observed 15 rare plant species at our total of 37 beaver ponds (Chapter 2). No significant differences were found among pond age classes and rare plant species richness. There was a significant influence of age class on pond species richness, with the youngest and oldest ponds similar (Chapter 2). Size and age of beaver ponds has little effect on vegetative community structure. However, whether the vegetative community was influenced by an impoundment was important. Communities inside and outside the influence had similar species richness and 
diversity, but those communities were distinctly different when considering the species which composed them (Chapter 2). Beaver ponds create habitats dominated by more obligate wetland vegetation than surrounding wetland areas (Chapter 2)

A map and model using GIS was found to be valid and better at predicting suitable beaver habitat than random chance alone (Chapter 3). Compared to the beaver HSI, the GIS model was similar when considering a $200 \mathrm{~m}$ buffer, but gave higher values when evaluating individual locations (Chapter 3). A model based on elevation, stream gradient, and proximity to water can accurately predict suitable beaver habitat (Chapter 3). Rare plant conservation can be aided by overlaying community information and calculating model values. In the study area, balsam fir (Abies balsamea) and thread rush (Juncus filiformis) were predicted to be most susceptible to beaver activity (Chapter 3).

\section{Conclusions}

As most vegetative community changes were evident upon gradient changes, topography and resulting hydrology may be important factors affecting community composition in this study. Similarly, basin morphology was found to be an important factor in vegetative composition in New Hampshire (Koning 2005). In this study, youngest ponds (1-6 yrs) show a higher species richness than ponds 7-56 years of age, but richness in oldest ponds ( $>56$ yrs) was similar to youngest ponds (Chapter 2). This eventual increase back to higher species richness may be due to stabilization of the wetland area after disturbance (Chapter 2).

Proximity to an impoundment was found to be a significant factor in determining herbaceous community composition. Our comparison of vegetation inside and outside the influence of impounded water indicates a community shift occurs as distance from ponds 
increases. This is likely representative of a decreasing water level as distance from a pond increases (Chapter 2).

Peripheral populations of rare plant species can experience lower genetic diversity than central populations and genetic isolation between populations, but they maintain similar fitness levels as core populations (Lammi et al. 1999). This may apply to other rare plant populations, such as those found in Canaan Valley, indicating they are still viable and may be able to expand or persist with conservation efforts. Although rare plant species do not occur in significantly higher numbers in these impoundments, there are clear trends indicating that older ponds may act as a refuge for greater numbers of these species (Chapter 2). We believe our lack of significance can be attributed to the small number of rare plant species observed, a problem inherent in studies of rare species. Protection of these oldest ponds is recommended to conserve rare wetland plant species in the study area.

Multiple studies have stressed the importance of physical factors, rather than vegetative, in determining beaver habitat (Jenkins 1980, Howard and Larson 1985). These observations were incorporated into our efforts, resulting in a valid model (Chapter 3). Modeling beaver habitat suitability can be performed using a combination of spatial datasets including stream gradient, distance to water, and woody plants. Creating a GIS-based model allows landscapelevel predictions with minimal field collection and higher accuracy than some site-specific models (Chapter 3). Larger, long-term impoundments often receive high suitability scores (Chapter 3), further indicating their importance in management of rare plant species (Chapter 2). In contrast, new beaver ponds may be a less suitable habitat for beaver (Chapter 3), support fewer rare plants (Chapter 2), and have potential to submerge additional flood-intolerant species. 
Our model is an effective landscape-level management tool that can be incorporated into rare plant conservation and beaver management decisions.

\section{Management Implications}

Management of beaver populations is recommended in Canaan Valley National Wildlife Refuge. In addition to rich, diverse floristic communities, wetlands in this area also harbor many regionally rare plant species and communities. Rare plant species may be negatively affected by various conditions, from trampling (Koning 2005) to low genetic diversity (Lammi et al. 1999). It is likely that these factors affect plant communities in Canaan Valley, and beaver population management may be necessary to benefit rare plant species, particularly to preserve developing coniferous communities.

Our data suggests older ponds may provide refuge for a greater number of rare plant species. One such species, Carex atherodes, occurs at the southern edge of its distribution, as do many species in this area. Peripheral populations of rare plants are more isolated than physical distance would suggest and are typically small, leading to the likelihood of low genetic diversity (see Lammi et al. 1999). Protection and management of the habitats in which these species occur is necessary to conserve these rare populations. Geomorphology is important in beaver habitat selection, as areas that allow large, expandable impoundments will be inhabited first (Johnston and Naiman 1990). This situation seems to have occurred in Canaan Valley, where the majority of large ponds were created early and most long-term ponds are indicated as highly suitable beaver habitat (Chapter 3). We believe that limited trapping, as long as it is monitored and regulated, in these areas would not adversely affect the persistence of these impoundments, as these older ponds should be preferred refuge for those remaining beavers in the population (Chapter 2). Where conservation of flood-intolerant species is desirable, it may be advisable to 
use techniques to deter beaver activity. These methods could include trapping or contraceptives to reduce area populations, or using pond leveling devices that would reduce their expansion and potentially drive colonies away from the area. The landscape conditions that require these deterrence activities may best be determined by a combination of rare plant mapping and beaver habitat modeling. However, trapping is probably the most practical means of controlling beaver.

Our model gives managers the ability to spatially reference areas that are likely to be affected by beaver activity. The particular advantage of this model is the minimal amount of data collection required, in contrast with more intensive vegetation surveys required for models such as the HSI. This habitat mapping can be applied toward preservation of target vegetative communities, particularly rare plant species or those species intolerant of sustained flooding. The GIS model also may provide insight in determining high populations of beaver. Beaver activity in low value habitats might indicate that all highly suitable areas are exhausted or currently inhabited. These indicators should be useful to land managers when making decisions concerning beaver populations or the vegetative communities they may affect.

At CVNWR in particular, beaver trapping should take place in areas near balsam fir, as it receives a high model value but does not tolerate sustained flooding. In areas near fir stands that are inaccessible for trappers, such as the Big Cove area, deterrence methods may be a preferable alternative. Trapping should be avoided or kept to a minimum around the oldest ponds, particularly those in Glade Run. The largest pond in this area supports the only known population of Carex atherodes, among several other rare plant species. Although trapping could occur for nearby colonies and ponds, beaver presence in ponds such as this should be maintained. Beavers in these areas will maintain and possible expand habitat for rare plant species, requiring some degree of beaver population conservation. There is a great deal of data 
on rare plant species in Canaan Valley. Use of our findings and our GIS model will help further conservation efforts concerning these rare species if incorporated into beaver management actions.

We suggest our GIS model could be used as a management tool in areas similar to our study area, particularly in the northeastern United States. However, food preferences in any local areas should be taken into account. Additionally, other limitations are inherent in GIS use. Particularly, the accuracy and availability of these datasets are not equal for all areas. Mapping from this model should improve as NWI and vegetation/community cover layers are updated and become more accurate. Although aerial photographs show some large beaver ponds that are not ranked highest by the model, the changes caused by beavers in the past can alter the flow of stream systems, thereby affecting the accuracy of any stream layer. In mountainous areas similar to our study site, the steep gradients adjacent to water cover may limit the spatial extent of beaver use. Finer scale digital elevation models may be necessary before this factor can be incorporated into this type of model. The continual improvement in GIS is critical to this type of application. The most accurate, smallest scale layers should always be incorporated into mapping efforts if available.

\section{Future Research}

More research is needed in respect to beaver impoundments and their effects on vegetative communities. Future research should focus on population dynamics of rare plant species in beaver influenced areas. Genetic analyses, particularly of periphery populations, may be important in determining the conservation value of these isolated rare populations (Lammi et 
al. 1999). Intensive sampling of rare plant communities, including area or abundance data, would also be beneficial to predicting the potential beaver activity effects using our GIS model.

Comparisons of beaver impounded areas to unaltered stream habitats may also be instrumental in vegetative conservation. Areas outside the influence of the beaver pond were defined by wetland vegetation (Chapter 2), indicating that other factors may be important in determining the wetland vegetation. Sampling comparable sites that are not impounded may give more insight into the types of vegetative changes a beaver pond produces. Moreover, vegetative communities are often dictated by soil nutrients, type, and moisture (Barbour et al. 1987). These factors were not sampled during this study. However, they have the potential to influence species composition, growth, and persistence. Future studies of vegetation in beaver habitats may require the incorporation of these variables into sampling and analyses.

Although we did not incorporate beaver activity levels into our research, we believe this may be important in determining vegetative characteristics of the area. Particularly, changes that occur after abandonment may be ecologically important. Soil properties may differ in abandoned areas versus areas that are active and are not being drained. Comparing current active ponds to areas where ponds once occurred may provide more insight into the important properties leading to habitat for rare plant species.

Further analysis of our model should be performed in areas unlike the landscape of West Virginia. Previously described improvements, if available, could be incorporated to improve performance in alternate locations. Research to improve modeling efforts could focus on herbaceous food preferences. Although woody food preferences have been extensively studied (Chapter 1), many modeling attempts have shown little explanatory power in using locations of preferred woody vegetation (Chapter 3). This focus on woody vegetation is due to reliance on 
food caches for some populations in winter, but beavers in warmer climates do not require this food source. Research into the herbaceous preferences of beaver may help further increase the predictive power of habitat suitability modeling across landscapes.

\section{$\underline{\text { Literature Cited }}$}

Allen, A.W. 1983. Habitat suitability index models: Beaver. U.S. Fish and Wildlife Service. FWS/OBS-82/10.30 Revised. 20pp.

Balcombe, C.K., J.T. Anderson, R.H. Fortney, J.S. Rentch, W.N. Grafton, and W.S. Kordek. 2005. A comparison of plant communities in mitigation and reference wetlands in the mid-Appalachians. Wetlands 25:130-142.

Barbour, M. G., J. H. Burk, and W. D. Pitts. 1987. Terrestrial plant ecology, second edition. The Benjamin/Cummings Publishing Company, Inc., Menlo Park, CA, USA.

Barnes, W.J. and E. Dibble. 1988. The effects of beaver in riverbank forest succession. Canadian Journal of Botany 66:40-44.

Beier, P. and R.H. Barrett. 1987. Beaver habitat use and impact in the Truckee River Basin, California. Journal of Wildlife Management 51:794-799.

Beverage, W. 1967. Soil survey, Tucker County, part of northern Randolph County, West Virginia. USDA Soil Conservation Service, and Forest Service, Washington, DC.

Fortney, R. H. 1993. Canaan Valley - An area of special interest within the upland forest region. In S. L. Stephenson (ed.) Upland Forests of West Virginia. McClain Printing Co., Parsons, West Virginia, USA.

Fortney, R. H. and J. S. Rentch. 2003. Post logging era plant successional trends and geospatial vegetation patterns in Canaan Valley, West Virginia, 1945 to 2000. Castanea 68:317334. 
Gabler, K.I., J.W. Laundré, and L.T. Heady. 2000. Predicting the suitability of habitat in southeast Idaho for pygmy rabbits. Journal of Wildlife Management 64:759-764.

Howard, R.J. and J.S. Larson. 1985. A stream habitat classification system for beaver. Journal of Wildlife Management 49:19-25.

Jenkins, S.H. 1980. A size-distance relation in food selection by beavers. Ecology 61:740-746.

Johnston, C. A. and R. J. Naiman. 1990. Aquatic patch creation in relation to beaver population trends. Ecology 71:1617-1621.

Koning, C. O. 2005. Vegetation patterns resulting from spatial and temporal variability in hydrology, soils, and trampling in an isolated basin marsh, New Hampshire, USA. Wetalnds 25:239-251.

Lammi, A., P. Siikamäki, and K. Mustajärvi. 1999. Genetic diversity, population size, and fitness in central and peripheral populations of a rare plant Lychnis viscaria. Conservation Biology 13:1069-1078.

Macdonald, D.W., F.H. Tattersall, S. Rushton, A.B. South, S. Rao, P. Maitland, and R. Strachan. 2000. Reintroducing the beaver (Castor fiber) to Scotland: a protocol for identifying and assessing suitable release sites. Animal Conservation 3:125-133.

Mitchell, C.C. and W.A. Niering. 1993. Vegetation change in a topogenic bog following beaver flooding. Bulletin of the Torrey Botanical Club 120:136-147.

Naiman, R.J., J.M. Melillo, and J.E. Hobbie. 1986. Ecosystem alteration of boreal forest streams by beaver (Castor canadensis). Ecology 67:1254-1269.

Naiman, R.J., C A. Johnston, and J.C. Kelley. 1988. Alteration of North American streams by beaver. Bioscience 38:753-762. 
National Climate Data Center (NCDC), National Oceanographic and Atmospheric Administration (NOAA). 2003. http://www1.ncdc.noaa.gov/pub/orders.

Southeast Regional Climate Center. 1996. http://www.dnr.sc.gov/climate/sercc/index.html

Suzuki, N. and W.C. McComb. 1998. Habitat classification models for beaver (Castor canadensis) in the streams of the central Oregon coast range. Northwest Science 72:102-110.

Swank, W.G. 1949. Beaver ecology and management in West Virginia. Conservation Commission of West Virginia, Division of Game Management, Bulletin No. 1.

Wright, J. P., C. G. Jones, and A. S. Flecker. 2002. An ecosystem engineer, the beaver, increases species richness at the landscape scale. Oecologia 132:96-101. 

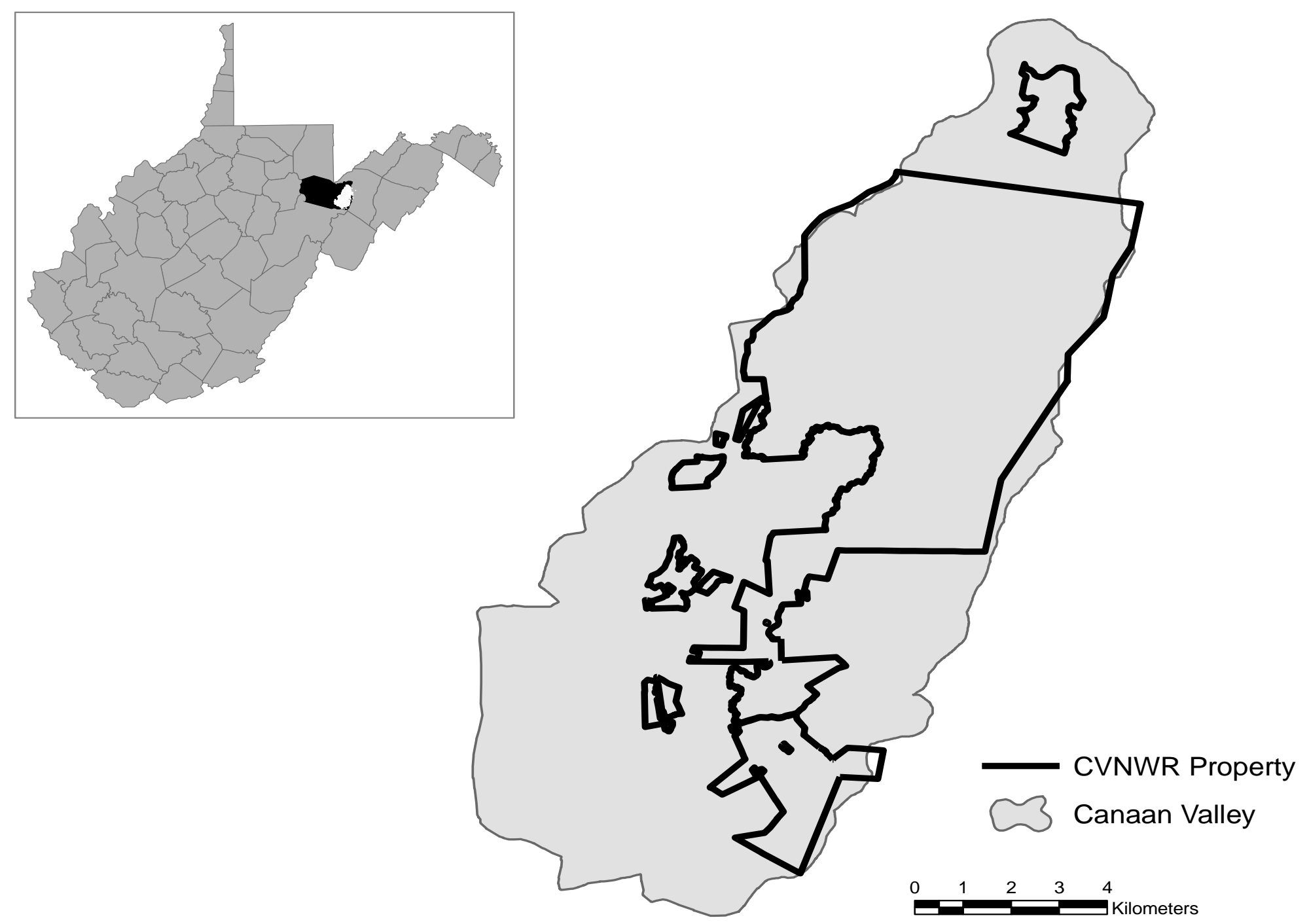

Figure 1. Canaan Valley National Wildlife Refuge (CVNWR) boundaries are shown in black over the gray area of Canaan Valley. Inset shows Canaan Valley located in Tucker County, WV, USA. 
Appendix 1. Rare wetland species known to occur in Canaan Valley, West Virginia, USA.

Nomenclature follows Kartesz (1999).

\begin{tabular}{|c|c|c|c|c|}
\hline Scientific Name & Common Name & Global $^{\mathrm{a}}$ & State $^{b}$ & $\mathrm{WIS}^{\mathrm{c}}$ \\
\hline Abies balsamea & Balsam Fir & G5 & S3 & fac \\
\hline Campanula aparinoides & Marsh bellflower & G5 & S3 & obl \\
\hline Carex aestivalis & Summer sedge & G4 & $\mathrm{S} 2$ & fac \\
\hline Carex atherodes & Awned Sedge & G5 & $\mathrm{S} 1$ & obl \\
\hline Carex bromoides & Brome-like sedge & G5 & $\mathrm{S} 2$ & facw + \\
\hline Carex canescens & Hoary sedge & G5 & S3 & obl \\
\hline Carex comosa & Bearded Sedge & G5 & $\mathrm{S} 2$ & obl \\
\hline Carex leptonervia & Finely-nerved Sedge & G4 & $\mathrm{S} 1$ & facw \\
\hline Carex projecta & Necklace Sedge & G5 & $\mathrm{S} 1$ & facw \\
\hline Coptis trifolia & Goldthread & G5T5 & $\mathrm{S} 2$ & facw \\
\hline Cuscuta rostrata & Beaked Dodder & G4 & $\mathrm{S} 2$ & NL \\
\hline Cypripedium reginae & Showy lady's-slipper & G4 & $\mathrm{S} 1$ & facw \\
\hline Dalibarda repens & Star violet & G5 & S3 & fac \\
\hline Drosera rotundifolia & Roundlew sundew & G5 & S3 & obl \\
\hline Equisetum sylvaticum & Woodland horsetail & G5 & $\mathrm{S} 1$ & facw \\
\hline Euphorbia purpurea & Glade Spurge & G3 & $\mathrm{S} 2$ & fac \\
\hline Geum aleppicum & Yellow avens & G5 & $\mathrm{S} 1$ & fac \\
\hline Geum rivale & Purple avens & G5 & $\mathrm{S} 1$ & obl \\
\hline Glyceria grandis & American manna-grass & G5 & $\mathrm{S} 2$ & obl \\
\hline Glyceria laxa & Northern manna-grass & G5 & $\mathrm{S} 1$ & NL \\
\hline
\end{tabular}


Appendix 1. continued

\begin{tabular}{|c|c|c|c|c|}
\hline Scientific Name & Common Name & Global $^{\mathrm{a}}$ & State $^{b}$ & $\mathrm{WIS}^{\mathrm{c}}$ \\
\hline Juncus filiformis & Thread Rush & G5 & $\mathrm{S} 2$ & facw \\
\hline Listera smallii & Kidney-leaf twayblade & G4 & $\mathrm{S} 2$ & facw \\
\hline Polemonium vanbruntiae & Jacob's ladder & G3 & $\mathrm{S} 2$ & facw \\
\hline Rhamnus alnifolia & Alder-leaved buckthorn & G5 & S1 & obl \\
\hline Salix discolor & Glaucous willow & G5 & $\mathrm{S} 2$ & facw \\
\hline Saxifraga pensylvanica & Swamp Saxifrage & G5 & $\mathrm{S} 2$ & obl \\
\hline Schoenoplectus purshianus & Weakstalk bulrush & G4G5 & S3 & obl \\
\hline Scirpus atrocinctus & Black-girdle bulrush & G5 & S3 & facw + \\
\hline Scirpus microcarpus & Small-fruit bulrush & G5 & S3 & obl \\
\hline Synosma suaveolens & Sweet-scented Indian plantain & G3 & S2 & fac- \\
\hline Thelypteris simulata & Bog Fern & G4G5 & S1 & facw \\
\hline Vaccinium oxycoccos & Small cranberry & G5 & $\mathrm{S} 2$ & obl \\
\hline Veronica scutellata & Marsh speedwell & G5 & $\mathrm{S} 1$ & obl \\
\hline Viburnum opulus americanum & Highbush cranberry & G5T5 & $\mathrm{S} 1$ & facw \\
\hline Zigadenus leimanthoides & Oceanorus & G4Q & $\mathrm{S} 2$ & obl \\
\hline
\end{tabular}

a Global indicates the status of each species across its range: $G 1=$ critically impaired, G2= imperiled, G3= vulnerable, G4= apparently secure, G5= secure.

b State shows the status of each species in West Virginia: $\mathrm{S} 1=$ critically impaired; $\mathrm{S} 2=$ imperiled, S3= vulnerable, S4= apparently secure, and S5= secure.

c WIS indicates the wetland indicator status of each species (U.S. Fish and Wildlife Service 1996). Possible status, in order of decreasing wetland fidelity: obligate (obl), 
facultative wetland (facw), facultative (fac), facultative upland (facu), and upland (upl). $\mathrm{NL}=$ not listed. 
Appendix 2. Herbaceous species occurring around beaver ponds in Canaan Valley, West Virginia, USA based on mean percent cover. Of four cover types and 153 species observed during transects, only 26 had a mean occurrence of $>1 \%$ cover in surveyed plots. Cover types are shown in bold. Maximum cover (Max) is a percentage. Ponds indicates the number of ponds at which each species occurred. Species names standardized according to Kartesz (1999).

\begin{tabular}{|c|c|c|c|c|c|}
\hline & Mean & St. Dev. & Sum & Max & Ponds \\
\hline Bryophytes & 23.181 & 16.667 & 880.882 & 68.83 & 38 \\
\hline Rubus hispidus & 17.816 & 11.981 & 676.994 & 47.22 & 36 \\
\hline Open Water & 9.333 & 8.761 & 354.672 & 32.38 & 31 \\
\hline Rock/Bare Ground & 8.894 & 9.097 & 337.959 & 35.75 & 34 \\
\hline Solidago uliginosa & 7.662 & 7.637 & 291.166 & 25.83 & 31 \\
\hline Calamagrostis canadensis & 3.258 & 6.248 & 123.822 & 28.646 & 17 \\
\hline Solidago rugosa & 2.858 & 3.757 & 108.606 & 15.23 & 25 \\
\hline Danthonia compressa & 2.845 & 3.765 & 108.096 & 13.09 & 23 \\
\hline Juncus effusus & 2.71 & 2.97 & 102.972 & 13.18 & 31 \\
\hline Woody Debris & 2.542 & 2.219 & 96.593 & 9.886 & 36 \\
\hline Glyceria canadensis & 2.341 & 3.825 & 88.95 & 16.55 & 30 \\
\hline Torreyochloa pallida & 2.104 & 5.017 & 79.952 & 25.42 & 15 \\
\hline Carex echinata & 2.032 & 3.152 & 77.234 & 16.094 & 22 \\
\hline Dulichium arundinaceum & 1.958 & 6.041 & 74.422 & 26.91 & 8 \\
\hline Sparganium erectum & 1.606 & 2.889 & 61.023 & 11.5 & 22 \\
\hline Eriophorum virginicum & 1.544 & 5.523 & 58.69 & 30.78 & 11 \\
\hline Carex folliculata & 1.522 & 2.577 & 57.848 & 9.2 & 20 \\
\hline
\end{tabular}


Appendix 2. continued

\begin{tabular}{|c|c|c|c|c|c|}
\hline & Mean & St. Dev. & Sum & Max & Ponds \\
\hline Leersia oryzoides & 1.471 & 3.21 & 55.915 & 14.07 & 18 \\
\hline Sparganium americanum & 1.452 & 4.481 & 55.163 & 21.023 & 6 \\
\hline Carex canescens & 1.428 & 2.842 & 54.248 & 13.636 & 24 \\
\hline Galium tinctorium & 1.407 & 2.572 & 53.461 & 14.07 & 25 \\
\hline Triadenum virginicum & 1.394 & 2.016 & 52.961 & 7.5 & 29 \\
\hline Carex utriculata & 1.312 & 8.073 & 49.874 & 49.77 & 2 \\
\hline Juncus subcaudatus & 1.188 & 1.865 & 45.147 & 8.409 & 25 \\
\hline Eleocharis obtusa & 1.09 & 2.063 & 41.408 & 7.5 & 16 \\
\hline Pteridium aquilinum & 1.066 & 2.233 & 40.524 & 10.45 & 21 \\
\hline Hypericum ellipticum & 0.979 & 1.925 & 37.211 & 10.5 & 29 \\
\hline Euthamia graminifolia & 0.957 & 1.55 & 36.348 & 4.75 & 18 \\
\hline Carex scoparia var. scoparia & 0.919 & 1.326 & 34.939 & 5.63 & 26 \\
\hline Impatiens capensis & 0.798 & 1.916 & 30.311 & 7.5 & 12 \\
\hline Scirpus microcarpus & 0.714 & 1.922 & 27.124 & 9.09 & 12 \\
\hline Eleocharis tenuis & 0.692 & 1.867 & 26.311 & 9.33 & 15 \\
\hline Ludwigia palustris & 0.686 & 1.713 & 26.071 & 8.5 & 16 \\
\hline Doellingeria umbellata & 0.677 & 1.368 & 25.723 & 5.45 & 15 \\
\hline Eleocharis palustris & 0.603 & 2.164 & 22.914 & 11.67 & 5 \\
\hline Dichanthelium clandestinum & 0.567 & 1.211 & 21.557 & 4.77 & 14 \\
\hline Scirpus atrocinctus & 0.504 & 1.129 & 19.141 & 4.75 & 18 \\
\hline Carex debilis & 0.503 & 1.397 & 19.115 & 6.731 & 15 \\
\hline Carex atlantica & 0.502 & 1.739 & 19.09 & 10.17 & 9 \\
\hline
\end{tabular}


Appendix 2. continued

\begin{tabular}{|c|c|c|c|c|c|}
\hline & Mean & St. Dev. & Sum & Max & Ponds \\
\hline Carex lurida & 0.485 & 0.884 & 18.421 & 3.57 & 16 \\
\hline Lycopodium obscurum & 0.475 & 1.094 & 18.068 & 4.72 & 12 \\
\hline Potentilla simplex & 0.428 & 0.999 & 16.267 & 4.32 & 13 \\
\hline Agrostis hyemalis & 0.362 & 1.01 & 13.75 & 4.77 & 12 \\
\hline Hypericum mutilum & 0.354 & 0.798 & 13.468 & 3.714 & 16 \\
\hline Osmunda cinnamomea & 0.336 & 1.144 & 12.775 & 5.31 & 7 \\
\hline Carex gynandra & 0.335 & 0.61 & 12.743 & 2.68 & 14 \\
\hline Callitriche heterophylla & 0.31 & 1.592 & 11.764 & 9.67 & 3 \\
\hline Potamogeton diversifolius & 0.305 & 0.793 & 11.6 & 3.52 & 10 \\
\hline Polygonum sagittatum & 0.282 & 0.457 & 10.709 & 1.812 & 21 \\
\hline Lycopus uniflorus & 0.274 & 0.712 & 10.409 & 3.33 & 14 \\
\hline Typha latifolia & 0.231 & 0.583 & 8.775 & 2.5 & 7 \\
\hline Polygonum hydropiper & 0.227 & 1.092 & 8.64 & 6.71 & 6 \\
\hline Carex crinita & 0.2 & 0.666 & 7.603 & 3.75 & 6 \\
\hline Bidens cernua & 0.195 & 1.162 & 7.41 & 7.17 & 3 \\
\hline Scirpus polyphyllus & 0.188 & 0.771 & 7.15 & 3.67 & 4 \\
\hline Carex atherodes & 0.181 & 1.113 & 6.86 & 6.86 & 1 \\
\hline Lycopus virginicus & 0.181 & 0.402 & 6.883 & 1.812 & 9 \\
\hline Apocynum androsaemifolium & 0.164 & 0.606 & 6.244 & 3.25 & 4 \\
\hline Glyceria grandis & 0.163 & 0.623 & 6.206 & 3.409 & 5 \\
\hline Glyceria striata & 0.16 & 0.526 & 6.076 & 2.95 & 9 \\
\hline Lycopodium clavatum & 0.16 & 0.904 & 6.094 & 5.577 & 3 \\
\hline
\end{tabular}


Appendix 2. continued

\begin{tabular}{|c|c|c|c|c|c|}
\hline & Mean & St. Dev. & Sum & Max & Ponds \\
\hline Lycopodium digitatum & 0.156 & 0.478 & 5.939 & 2.5 & 6 \\
\hline Vaccinium oxycoccos & 0.156 & 0.783 & 5.933 & 4.773 & 4 \\
\hline Callitriche terrestris & 0.155 & 0.462 & 5.892 & 2.357 & 6 \\
\hline Carex hirsutella & 0.15 & 0.698 & 5.708 & 4.231 & 5 \\
\hline Eleocharis acicularis & 0.149 & 0.921 & 5.68 & 5.68 & 1 \\
\hline Festuca subverticillata & 0.149 & 0.921 & 5.68 & 5.68 & 1 \\
\hline Glyceria melicaria & 0.148 & 0.913 & 5.63 & 5.63 & 1 \\
\hline Vallisneria americana & 0.148 & 0.641 & 5.63 & 3.13 & 2 \\
\hline Juncus brevicaudatus & 0.133 & 0.472 & 5.07 & 2.62 & 6 \\
\hline Carex leptalea ssp. leptalea & 0.126 & 0.337 & 4.77 & 1.25 & 7 \\
\hline Agrostis gigantea & 0.099 & 0.268 & 3.77 & 1.33 & 8 \\
\hline Thelypteris noveboracensis & 0.093 & 0.553 & 3.54 & 3.41 & 2 \\
\hline Thelypteris palustris & 0.093 & 0.327 & 3.525 & 1.5 & 5 \\
\hline Agrostis perennans & 0.09 & 0.553 & 3.41 & 3.41 & 1 \\
\hline Festuca trachyphylla & 0.09 & 0.553 & 3.41 & 3.41 & 1 \\
\hline Carex vulpinoidea & 0.083 & 0.297 & 3.16 & 1.5 & 5 \\
\hline Anthoxanthum odoratum & 0.079 & 0.229 & 3.016 & 1.33 & 9 \\
\hline Carex virescens & 0.079 & 0.487 & 3 & 3 & 1 \\
\hline Carex stipata & 0.072 & 0.275 & 2.726 & 1.571 & 4 \\
\hline Veronica americana & 0.071 & 0.388 & 2.686 & 2.386 & 3 \\
\hline Carex comosa & 0.066 & 0.406 & 2.5 & 2.5 & 1 \\
\hline Juncus tenuis & 0.066 & 0.264 & 2.507 & 1.59 & 6 \\
\hline
\end{tabular}


Appendix 2. continued

\begin{tabular}{|c|c|c|c|c|c|}
\hline & Mean & St. Dev. & Sum & Max & Ponds \\
\hline Sagittaria calycina & 0.064 & 0.321 & 2.429 & 1.929 & 2 \\
\hline Carex stricta & 0.063 & 0.389 & 2.396 & 2.396 & 1 \\
\hline Dryopteris carthusiana & 0.059 & 0.195 & 2.235 & 0.88 & 4 \\
\hline Viola macloskeyi & 0.056 & 0.25 & 2.11 & 1.46 & 3 \\
\hline Dichanthelium spherocarpon & 0.051 & 0.295 & 1.95 & 1.82 & 2 \\
\hline Dryopteris cristata & 0.05 & 0.143 & 1.903 & 0.682 & 6 \\
\hline Potamogeton pusillus & 0.049 & 0.305 & 1.88 & 1.88 & 1 \\
\hline Symphyotrichum dumosum & 0.044 & 0.258 & 1.69 & 1.59 & 2 \\
\hline Symphyotrichum praealtum & 0.042 & 0.258 & 1.59 & 1.59 & 1 \\
\hline Hieracium x floribundum & 0.039 & 0.221 & 1.464 & 1.36 & 2 \\
\hline Tiarella cordifolia & 0.039 & 0.221 & 1.474 & 1.36 & 2 \\
\hline Viola cucullata & 0.039 & 0.243 & 1.5 & 1.5 & 1 \\
\hline Bidens frondosa & 0.036 & 0.221 & 1.36 & 1.36 & 1 \\
\hline Drosera rotundifolia & 0.036 & 0.143 & 1.35 & 0.74 & 3 \\
\hline Dennstaedtia punctilobula & 0.035 & 0.166 & 1.349 & 1 & 3 \\
\hline Epilobium ciliatum & 0.035 & 0.216 & 1.33 & 1.33 & 1 \\
\hline Ranunculus acris & 0.031 & 0.19 & 1.17 & 1.17 & 1 \\
\hline Symphyotrichum puniceum & 0.03 & 0.075 & 1.154 & 0.36 & 7 \\
\hline Onoclea sensibilis & 0.029 & 0.153 & 1.117 & 0.938 & 3 \\
\hline Lycopodiella inundata & 0.026 & 0.162 & 1 & 1 & 1 \\
\hline Epilobium leptophyllum & 0.023 & 0.057 & 0.889 & 0.227 & 6 \\
\hline Rhynchospora alba & 0.022 & 0.097 & 0.85 & 0.47 & 2 \\
\hline
\end{tabular}


Appendix 2. continued

\begin{tabular}{|c|c|c|c|c|c|}
\hline & Mean & St. Dev. & Sum & Max & Ponds \\
\hline Schoenoplectus tabernaemontani & 0.021 & 0.089 & 0.793 & 0.5 & 3 \\
\hline Polygonum hydropiperoides & 0.02 & 0.086 & 0.77 & 0.5 & 3 \\
\hline Viola palustris & 0.02 & 0.088 & 0.767 & 0.455 & 2 \\
\hline Bartonia virginica & 0.019 & 0.069 & 0.74 & 0.29 & 3 \\
\hline Scutellaria lateriflora & 0.019 & 0.047 & 0.735 & 0.17 & 6 \\
\hline Chrysosplenium americanum & 0.018 & 0.111 & 0.682 & 0.682 & 1 \\
\hline Gaultheria procumbens & 0.018 & 0.11 & 0.68 & 0.68 & 1 \\
\hline Holcus lanatus & 0.018 & 0.085 & 0.67 & 0.5 & 2 \\
\hline Deschampsia flexuosa & 0.017 & 0.077 & 0.65 & 0.42 & 2 \\
\hline Poa palustris & 0.016 & 0.072 & 0.615 & 0.385 & 2 \\
\hline Achillea millefolium & 0.015 & 0.064 & 0.56 & 0.33 & 2 \\
\hline Rubus allegheniensis & 0.015 & 0.068 & 0.572 & 0.38 & 2 \\
\hline Botrychium dissectum & 0.012 & 0.073 & 0.45 & 0.45 & 1 \\
\hline Luzula bulbosa & 0.012 & 0.074 & 0.455 & 0.455 & 1 \\
\hline Carex lupulina & 0.011 & 0.07 & 0.43 & 0.43 & 1 \\
\hline Galium obtusum & 0.011 & 0.07 & 0.43 & 0.43 & 1 \\
\hline Acer rubrum & 0.01 & 0.044 & 0.384 & 0.227 & 2 \\
\hline Poa pratensis & 0.01 & 0.045 & 0.39 & 0.23 & 2 \\
\hline Carex tribuloides & 0.009 & 0.031 & 0.325 & 0.14 & 3 \\
\hline Sphenopholis pensylvanica & 0.009 & 0.043 & 0.35 & 0.25 & 2 \\
\hline Cardamine pensylvanica & 0.008 & 0.034 & 0.3 & 0.17 & 2 \\
\hline Carex swanii & 0.007 & 0.045 & 0.28 & 0.28 & 1 \\
\hline
\end{tabular}


Appendix 2. continued

\begin{tabular}{|c|c|c|c|c|c|}
\hline & Mean & St. Dev. & Sum & Max & Ponds \\
\hline Poa trivialis & 0.007 & 0.041 & 0.25 & 0.25 & 1 \\
\hline Agrostis stolonifera & 0.006 & 0.037 & 0.23 & 0.23 & 1 \\
\hline Antennaria neglecta & 0.006 & 0.037 & 0.23 & 0.23 & 1 \\
\hline Apocynum cannabinum & 0.006 & 0.037 & 0.23 & 0.23 & 1 \\
\hline Campanula aparinoides & 0.006 & 0.029 & 0.233 & 0.17 & 2 \\
\hline Carex baileyi & 0.006 & 0.037 & 0.23 & 0.23 & 1 \\
\hline Cinna arundinacea & 0.006 & 0.034 & 0.21 & 0.21 & 1 \\
\hline Juncus marginatus & 0.006 & 0.037 & 0.23 & 0.23 & 1 \\
\hline Lysimachia ciliata & 0.006 & 0.037 & 0.23 & 0.23 & 1 \\
\hline Prunella vulgaris & 0.006 & 0.037 & 0.23 & 0.23 & 1 \\
\hline Sisyrinchium angustifolium & 0.006 & 0.037 & 0.23 & 0.23 & 1 \\
\hline Houstonia serpyllifolia & 0.005 & 0.031 & 0.192 & 0.192 & 1 \\
\hline Najas flexilis & 0.005 & 0.029 & 0.18 & 0.18 & 1 \\
\hline Carex projecta & 0.004 & 0.026 & 0.16 & 0.16 & 1 \\
\hline Gentiana linearis & 0.004 & 0.023 & 0.14 & 0.14 & 1 \\
\hline Juncus canadensis & 0.004 & 0.028 & 0.17 & 0.17 & 1 \\
\hline Leersia virginica & 0.004 & 0.023 & 0.14 & 0.14 & 1 \\
\hline Packera aurea & 0.004 & 0.028 & 0.17 & 0.17 & 1 \\
\hline Panicum sp & 0.004 & 0.025 & 0.156 & 0.156 & 1 \\
\hline Ranunculus repens & 0.004 & 0.028 & 0.17 & 0.17 & 1 \\
\hline Rumex acetosella & 0.004 & 0.025 & 0.156 & 0.156 & 1 \\
\hline Rumex crispus & 0.004 & 0.028 & 0.17 & 0.17 & 1 \\
\hline
\end{tabular}


Appendix 2. continued

\begin{tabular}{lrrrrr}
\hline & Mean & St. Dev. & Sum & Max & Ponds \\
\hline Bidens tripartita & 0.003 & 0.019 & 0.12 & 0.12 & 1 \\
Clematis virginiana & 0.003 & 0.021 & 0.13 & 0.13 & 1 \\
Fragaria virginiana & 0.003 & 0.017 & 0.104 & 0.104 & 1 \\
Gratiola neglecta & 0.003 & 0.021 & 0.13 & 0.13 & 1 \\
Epilobium coloratum & 0.002 & 0.011 & 0.07 & 0.07 & 1 \\
Polygonum persicaria & 0.002 & 0.011 & 0.07 & 0.07 & 1 \\
\hline
\end{tabular}


Appendix 3. Shrub analysis for each pond based on average shrub cover percentage observed during surveys of beaver ponds in Canaan Valley, West Virginia, USA. Maximum cover is a percentage. Ponds indicates number of ponds at which each species was observed. Species names standardized according to Kartesz (1999).

\begin{tabular}{lccrr}
\hline Species & Mean & St. Dev. & Max Cover & Ponds \\
\hline Spiraea alba & 16.492 & 23.639 & 97.5 & 24 \\
Vaccinium myrtilloides & 4.425 & 10.097 & 50 & 14 \\
Salix sericea & 4.066 & 11.57 & 62.5 & 15 \\
Hypericum densiflorum & 3.543 & 11.05 & 62.5 & 13 \\
Alnus incana & 3.519 & 7.933 & 30.714 & 8 \\
Photinia melanocarpa & 2.76 & 14.782 & 85 & 4 \\
Viburnum recognitum & 1.681 & 6.578 & 37.5 & 10 \\
Ilex verticilata & 0.918 & 3.375 & 18.75 & 6 \\
Viburnum nudum & 0.806 & 2.026 & 7.5 & 8 \\
Populus tremuloides & 0.771 & 2.745 & 15 & 7 \\
Salix humilis & 0.069 & 0.307 & 1.667 & 2 \\
Prunus serotina & 0.038 & 0.218 & 1.25 & 1 \\
Ribes rotundifolium & 0.025 & 0.145 & 0.833 & 1 \\
Sambuca nigra & 0.025 & 0.145 & 0.833 & 1 \\
Vaccinium angustifolia & 0.013 & 0.073 & 0.417 & 1 \\
Tsuga canadensis & 0.005 & 0.029 & 0.167 & 1 \\
\hline & & & & \\
\hline
\end{tabular}


Appendix 4. Vegetation observed during walk around surveys of beaver ponds in Canaan Valley, WV, USA. Additional species includes all species not detected during transects but observed during the random walk-around surveys. All species names were standardized using Kartesz (1999). Observations indicates number of ponds at which each species was observed.

\begin{tabular}{|c|c|c|c|}
\hline Species & Observations & Species & Observations \\
\hline Abies balsamea & 2 & Mentha $\times$ piperita & 1 \\
\hline Arisaema triphyllum & 1 & Mimulus ringens & 6 \\
\hline Bromus kalmii & 1 & Nemopanthus mucronatus & 1 \\
\hline Bromus sp. & 1 & Osmunda claytoniana & 1 \\
\hline Calamagrostis coarctata & 2 & Oxalis stricta & 1 \\
\hline Callitriche palustris & 1 & Phalaris arundinacea & 1 \\
\hline Carex emoryi & 1 & Photinia melanocarpa & 3 \\
\hline Carex intumescens & 2 & Platanthera clavellata & 2 \\
\hline Carex laxiculmis & 1 & Polygala sanguinea & 1 \\
\hline Carex scabrata & 1 & Ribes rotundifolium & 2 \\
\hline Chelone glabra & 1 & Rorippa palustris ssp. fernaldiana & 1 \\
\hline Cirsium vulgare & 1 & Rosa palustris & 1 \\
\hline Clinopodium vulgare & 1 & Sambucus nigra & 2 \\
\hline Elymus canadensis & 2 & Scirpus cyperinus & 1 \\
\hline Eupatorium perfoliatum & 2 & Solidago nemoralis & 1 \\
\hline Eupatorium pilosum & 1 & Sphenopholis intermedia & 1 \\
\hline Galeopsis tetrahit & 1 & Spiranthes cernua & 1 \\
\hline Galium asprellum & 1 & Symphyotrichum lanceolatum & 1 \\
\hline
\end{tabular}


Appendix 4. continued

\begin{tabular}{lclc}
\hline Species & Observations & Species & Observations \\
\hline Glyceria laxa & 1 & Symplocarpus foetidus & 1 \\
Hypericum canadense & 1 & Thalictrum pubescens & 1 \\
Hypericum punctatum & 2 & Tsuga canadensis & 2 \\
Juncus filiformis & 1 & Verbena hastata & 1 \\
Leucanthemum vulgare & 1 & Veronica scutellata & 2 \\
Lobelia spicata & 1 & Viola sagittata & 1 \\
\end{tabular}


Appendix 5. Locations of rare plant species in Canaan Valley, West Virginia, USA.

Coordinates (X, Y) are displayed in North American Datum 1927. Global indicates global status of a species; state indicates status of species in West Virginia. Species names are standardized according to Kartesz (1999).

\begin{tabular}{|c|c|c|c|c|}
\hline Scientific Name & $\mathrm{X}$ & $\mathrm{Y}$ & Global & State \\
\hline Abies balsamea & 632307.8000 & 4322921.0300 & G5 & S3 \\
\hline Abies balsamea & 633528.0800 & 4319025.4600 & G5 & S3 \\
\hline Abies balsamea & 634059.1300 & 4321748.0600 & G5 & S3 \\
\hline Abies balsamea & 635168.3800 & 4325775.7700 & G5 & S3 \\
\hline Abies balsamea & 636256.2000 & 4325424.5100 & G5 & S3 \\
\hline Abies balsamea & 637326.6700 & 4327447.5300 & G5 & S3 \\
\hline Abies balsamea & 637764.7900 & 4328503.6700 & G5 & S3 \\
\hline Abies balsamea & 639141.2000 & 4328127.0400 & G5 & S3 \\
\hline Abies balsamea & 639980.6507 & 4333103.7706 & G5 & S3 \\
\hline Abies balsamea & 641854.4300 & 4330920.1400 & G5 & S3 \\
\hline Carex aestivalis & 637702.5900 & 4332048.8600 & G4 & S2 \\
\hline Carex atlantica & 632918.0600 & 4320957.8100 & G5T5 & $\mathrm{SH}$ \\
\hline Carex bromoides & 634842.8000 & 4323734.9700 & G5 & S2 \\
\hline Carex bromoides & 636748.1300 & 4327439.7500 & G5 & S2 \\
\hline Carex canescens & 636474.8550 & 4322273.8583 & G5 & S3 \\
\hline Carex canescens & 637107.0747 & 4329250.7297 & G5 & S3 \\
\hline Carex canescens & 637135.6800 & 4330127.0200 & G5 & S3 \\
\hline Carex canescens & 637298.8700 & 4327662.9100 & G5 & S3 \\
\hline
\end{tabular}


Appendix 5. continued

\begin{tabular}{|c|c|c|c|c|}
\hline Scientific Name & $\mathrm{X}$ & $\mathrm{Y}$ & Global & State \\
\hline Carex canescens & 637949.7340 & 4331714.2808 & G5 & S3 \\
\hline Carex canescens & 638011.3552 & 4331757.5341 & G5 & S3 \\
\hline Carex canescens & 638074.1600 & 4331407.8000 & G5 & S3 \\
\hline Carex canescens & 638284.6100 & 4329006.2000 & G5 & S3 \\
\hline Carex canescens & 638867.1843 & 4330888.4407 & G5 & S3 \\
\hline Carex canescens & 638870.3900 & 4328492.3000 & G5 & S3 \\
\hline Carex canescens & 638873.2524 & 4330935.9351 & G5 & S3 \\
\hline Carex canescens & 639132.9650 & 4330300.0911 & G5 & S3 \\
\hline Carex canescens & 639227.8477 & 4330093.0766 & G5 & S3 \\
\hline Carex canescens & 639250.2500 & 4332816.2800 & G5 & S3 \\
\hline Carex canescens & 639692.6894 & 4330862.0231 & G5 & S3 \\
\hline Carex canescens & 639980.6600 & 4333103.7706 & G5 & S3 \\
\hline Carex canescens & 640100.5347 & 4333036.4673 & G5 & S3 \\
\hline Carex canescens & 640189.2685 & 4327004.1760 & G5 & S3 \\
\hline Carex canescens & 640214.4500 & 4327442.9611 & G5 & S3 \\
\hline Carex canescens & 640284.1000 & 4327376.4300 & G5 & S3 \\
\hline Carex canescens & 641171.1800 & 4328933.2210 & G5 & S3 \\
\hline Carex canescens & 641293.4150 & 4328720.5400 & G5 & S3 \\
\hline Carex canescens & 641325.5788 & 4328965.5966 & G5 & S3 \\
\hline Carex canescens & 642898.3300 & 4335472.4771 & G5 & S3 \\
\hline Carex leptonervia & 639913.6800 & 4329281.7500 & G4 & S1 \\
\hline Cuscuta rostrata & 640104.3700 & 4332060.5400 & G4 & $\mathrm{S} 2$ \\
\hline
\end{tabular}


Appendix 5. continued

\begin{tabular}{|c|c|c|c|c|}
\hline Scientific Name & $\mathrm{X}$ & $\mathrm{Y}$ & Global & State \\
\hline Dalibarda repens & 631849.4200 & 4320138.1100 & G5 & S3 \\
\hline Dalibarda repens & 632063.7800 & 4323132.7800 & G5 & S3 \\
\hline Dalibarda repens & 633410.4300 & 4318869.2900 & G5 & S3 \\
\hline Dalibarda repens & 634439.5400 & 4326225.8200 & G5 & S3 \\
\hline Dalibarda repens & 636616.6000 & 4326818.4200 & G5 & S3 \\
\hline Dalibarda repens & 636844.1400 & 4326174.8000 & G5 & S3 \\
\hline Dalibarda repens & 638265.8600 & 4327340.6600 & G5 & S3 \\
\hline Dalibarda repens & 638280.1300 & 4327895.9800 & G5 & S3 \\
\hline Dalibarda repens & 638908.5900 & 4327691.2000 & G5 & S3 \\
\hline Dalibarda repens & 639900.3400 & 4325981.9000 & G5 & S3 \\
\hline Dalibarda repens & 641123.0400 & 4328840.8200 & G5 & S3 \\
\hline Eupatorium pilosum & 632671.6400 & 4324160.6000 & G5 & $\mathrm{SH}$ \\
\hline Euphorbia purpurea & 633121.9600 & 4321701.3200 & G3 & S2 \\
\hline Euphorbia purpurea & 633256.7300 & 4319421.7400 & G3 & S2 \\
\hline Euphorbia purpurea & 633358.6700 & 4319084.2800 & G3 & S2 \\
\hline Euphorbia purpurea & 634707.7700 & 4321789.9700 & G3 & S2 \\
\hline Euphorbia purpurea & 636407.7900 & 4327770.7300 & G3 & S2 \\
\hline Euphorbia purpurea & 637852.7600 & 4328967.7700 & G3 & $\mathrm{S} 2$ \\
\hline Geum rivale & 633256.7400 & 4319421.7400 & G5 & S1 \\
\hline Geum rivale & 633358.6800 & 4319084.2600 & G5 & S1 \\
\hline Glyceria grandis & 634660.7400 & 4321727.4900 & G5 & S2 \\
\hline Glyceria grandis & 635411.3500 & 4325625.7700 & G5 & $\mathrm{S} 2$ \\
\hline
\end{tabular}


Appendix 5. continued

\begin{tabular}{|c|c|c|c|c|}
\hline Scientific Name & $\mathrm{X}$ & $\mathrm{Y}$ & Global & State \\
\hline Glyceria grandis & 635925.0700 & 4325110.4100 & G5 & S2 \\
\hline Glyceria grandis & 636492.7700 & 4325644.4700 & G5 & S2 \\
\hline Glyceria grandis & 637316.4300 & 4328033.2600 & G5 & S2 \\
\hline Glyceria grandis & 637761.0000 & 4328719.4600 & G5 & $\mathrm{S} 2$ \\
\hline Glyceria grandis & 638974.1200 & 4328062.4100 & G5 & $\mathrm{S} 2$ \\
\hline Glyceria grandis & 641171.1750 & 4328933.2210 & G5 & $\mathrm{S} 2$ \\
\hline Glyceria grandis & 641418.1870 & 4329404.3967 & G5 & $\mathrm{S} 2$ \\
\hline Glyceria grandis & 642089.0200 & 4331232.7700 & G5 & $\mathrm{S} 2$ \\
\hline Juncus filiformis & 634877.1400 & 4321731.2000 & G5 & $\mathrm{S} 2$ \\
\hline Juncus filiformis & 640781.7400 & 4328343.9610 & G5 & S2 \\
\hline Listera smallii & 633412.0000 & 4318776.8100 & G4 & S2 \\
\hline Lonicera canadensis & 635603.7500 & 4321435.3200 & G5 & $\mathrm{S} 2$ \\
\hline Oenothera pilosella & 634660.2900 & 4327370.5500 & G5 & S2 \\
\hline Pogonia ophioglossoides & 636844.1200 & 4326174.8000 & G5 & $\mathrm{S} 2$ \\
\hline Polemonium vanbruntiae & 631857.1600 & 4319675.7100 & G3 & S2 \\
\hline Polemonium vanbruntiae & 633358.6700 & 4319084.2600 & G3 & $\mathrm{S} 2$ \\
\hline Polemonium vanbruntiae & 633415.0000 & 4322086.0000 & G3 & S2 \\
\hline Polemonium vanbruntiae & 633427.7300 & 4322107.3700 & G3 & $\mathrm{S} 2$ \\
\hline Polemonium vanbruntiae & 634294.0500 & 4319254.3400 & G3 & $\mathrm{S} 2$ \\
\hline Polemonium vanbruntiae & 634877.1500 & 4321731.2000 & G3 & S2 \\
\hline Polemonium vanbruntiae & 635480.2600 & 4325811.9800 & G3 & $\mathrm{S} 2$ \\
\hline Polemonium vanbruntiae & 636561.1200 & 4325861.5100 & G3 & $\mathrm{S} 2$ \\
\hline
\end{tabular}


Appendix 5. continued

\begin{tabular}{|c|c|c|c|c|}
\hline Scientific Name & $\mathrm{X}$ & $\mathrm{Y}$ & Global & State \\
\hline Polemonium vanbruntiae & 637852.7700 & 4328967.7700 & G3 & S2 \\
\hline Polemonium vanbruntiae & 639070.7000 & 4333460.6800 & G3 & S2 \\
\hline Polemonium vanbruntiae & 642089.0150 & 4331232.7700 & G3 & $\mathrm{S} 2$ \\
\hline Polemonium vanbruntiae & 642137.5500 & 4335180.9300 & G3 & $\mathrm{S} 2$ \\
\hline Polemonium vanbruntiae & 641302.9370 & 4328959.0718 & G3 & S2 \\
\hline Rhamnus alnifolia & 631881.2100 & 4319676.1100 & G5 & $\mathrm{S} 1$ \\
\hline Rhamnus alnifolia & 633171.0900 & 4321640.4800 & G5 & S1 \\
\hline Rhamnus alnifolia & 633358.6600 & 4319084.2700 & G5 & S1 \\
\hline Rhamnus alnifolia & 636654.0300 & 4326048.1500 & G5 & S1 \\
\hline Rhamnus alnifolia & 638350.7000 & 4329346.5700 & G5 & S1 \\
\hline Salix discolor & 637842.8200 & 4328165.8300 & G5 & S2 \\
\hline Salix discolor & 640511.2519 & 4327787.2713 & G5 & $\mathrm{S} 2$ \\
\hline Salix discolor & 641171.1650 & 4328933.2210 & G5 & S2 \\
\hline Saxifraga pensylvanica & 633391.6100 & 4318560.6100 & G5 & $\mathrm{S} 2$ \\
\hline Schoenoplectus purshianus & 639384.7761 & 4330388.6412 & G4G5 & S3 \\
\hline Scirpus atrocinctus & 631881.2200 & 4319676.1100 & G5 & S3 \\
\hline Scirpus atrocinctus & 633063.2900 & 4319480.1400 & G5 & S3 \\
\hline Scirpus atrocinctus & 633427.7400 & 4322107.3700 & G5 & S3 \\
\hline Scirpus atrocinctus & 634564.0400 & 4321756.6700 & G5 & S3 \\
\hline Scirpus atrocinctus & 634962.9900 & 4323737.0300 & G5 & S3 \\
\hline Scirpus atrocinctus & 635448.3800 & 4327661.6300 & G5 & S3 \\
\hline Scirpus atrocinctus & 636407.7800 & 4327770.7600 & G5 & S3 \\
\hline
\end{tabular}


Appendix 5. continued

\begin{tabular}{|c|c|c|c|c|}
\hline Scientific Name & $\mathrm{X}$ & $\mathrm{Y}$ & Global & State \\
\hline Scirpus atrocinctus & 636474.8350 & 4322273.8583 & G5 & S3 \\
\hline Scirpus atrocinctus & 636492.7800 & 4325644.4700 & G5 & S3 \\
\hline Scirpus atrocinctus & 637107.0847 & 4329250.7297 & G5 & S3 \\
\hline Scirpus atrocinctus & 637842.8150 & 4328165.8300 & G5 & S3 \\
\hline Scirpus atrocinctus & 637949.7440 & 4331714.2808 & G5 & S3 \\
\hline Scirpus atrocinctus & 638011.3500 & 4331757.5341 & G5 & S3 \\
\hline Scirpus atrocinctus & 638151.1877 & 4331871.2962 & G5 & S3 \\
\hline Scirpus atrocinctus & 638720.1900 & 4327472.0100 & G5 & S3 \\
\hline Scirpus atrocinctus & 639132.9600 & 4330300.0911 & G5 & S3 \\
\hline Scirpus atrocinctus & 639227.8550 & 4330093.0766 & G5 & S3 \\
\hline Scirpus atrocinctus & 639638.8000 & 4332576.4800 & G5 & S3 \\
\hline Scirpus atrocinctus & 639692.6950 & 4330862.0231 & G5 & S3 \\
\hline Scirpus atrocinctus & 640189.2750 & 4327004.1760 & G5 & S3 \\
\hline Scirpus atrocinctus & 640214.4441 & 4327442.9611 & G5 & S3 \\
\hline Scirpus atrocinctus & 640756.1269 & 4328420.8210 & G5 & S3 \\
\hline Scirpus atrocinctus & 640781.7468 & 4328343.9610 & G5 & S3 \\
\hline Scirpus atrocinctus & 641171.1707 & 4328933.2210 & G5 & S3 \\
\hline Scirpus atrocinctus & 641325.5850 & 4328965.5966 & G5 & S3 \\
\hline Scirpus atrocinctus & 641418.1773 & 4329404.3967 & G5 & S3 \\
\hline Scirpus atrocinctus & 641569.4211 & 4329347.8466 & G5 & S3 \\
\hline Scirpus atrocinctus & 642898.3220 & 4335472.4771 & G5 & S3 \\
\hline Scirpus microcarpus & 632800.8100 & 4319352.3700 & G5 & S3 \\
\hline
\end{tabular}


Appendix 5. continued

\begin{tabular}{|c|c|c|c|c|}
\hline Scientific Name & $\mathrm{X}$ & $\mathrm{Y}$ & Global & State \\
\hline Scirpus microcarpus & 633949.4800 & 4319711.0100 & G5 & S3 \\
\hline Scirpus microcarpus & 635180.2600 & 4325811.9800 & G5 & S3 \\
\hline Scirpus microcarpus & 635848.1800 & 4325386.6100 & G5 & S3 \\
\hline Scirpus microcarpus & 637135.6900 & 4330127.0200 & G5 & S3 \\
\hline Scirpus microcarpus & 637298.8800 & 4327662.9100 & G5 & S3 \\
\hline Scirpus microcarpus & 637949.7600 & 4331652.3100 & G5 & S3 \\
\hline Scirpus microcarpus & 638103.4500 & 4329743.1000 & G5 & S3 \\
\hline Scirpus microcarpus & 638386.9500 & 4321822.9500 & G5 & S3 \\
\hline Scirpus microcarpus & 641293.4200 & 4328720.5400 & G5 & S3 \\
\hline Scirpus microcarpus & 641920.3400 & 4331260.5500 & G5 & S3 \\
\hline Stachys tenuifolia & 635644.2200 & 4326061.5000 & G5T4Q & S2 \\
\hline Synosma suaveolens & 634442.7700 & 4321816.2800 & G3 & $\mathrm{S} 2$ \\
\hline Synosma suaveolens & 634707.7900 & 4321789.9700 & G3 & S2 \\
\hline Synosma suaveolens & 636118.4100 & 4325052.0800 & G3 & $\mathrm{S} 2$ \\
\hline Synosma suaveolens & 637990.3900 & 4329340.2300 & G3 & $\mathrm{S} 2$ \\
\hline Synosma suaveolens & 638726.8000 & 4328458.9200 & G3 & $\mathrm{S} 2$ \\
\hline Thelypteris simulata & 641920.3500 & 4331260.5500 & G4G5 & S1 \\
\hline Torreyochloa pallida & 634752.4500 & 4326200.3400 & G5?T4Q & S2 \\
\hline Torreyochloa pallida & 637316.4400 & 4328033.2600 & G5?T4Q & S2 \\
\hline Torreyochloa pallida & 637715.6600 & 4328564.4800 & G5?T4Q & S2 \\
\hline Torreyochloa pallida & 638974.1300 & 4328062.4100 & G5?T4Q & $\mathrm{S} 2$ \\
\hline Vaccinium oxycoccos & 639132.9750 & 4330300.0911 & G5 & $\mathrm{S} 2$ \\
\hline
\end{tabular}


Appendix 5. continued

\begin{tabular}{lcccr}
\hline Scientific Name & X & Y & Global & State \\
\hline Vaccinium oxycoccos & 639227.8400 & 4330093.0766 & G5 & S2 \\
Vaccinium oxycoccos & 639692.6850 & 4330862.0231 & G5 & S2 \\
Veronica scutellata & 634660.7500 & 4321727.4900 & G5 & S1 \\
Viburnum opulus americanum & 633165.8800 & 4321948.7500 & G5T5 & S1 \\
Viburnum opulus americanum & 638350.7100 & 4329346.5700 & G5T5 & S1 \\
Viola appalachiensis & 631979.9900 & 4319523.5900 & G3 & S2S3 \\
Viola appalachiensis & 634066.0500 & 4319928.8500 & G3 & S2S3 \\
Zigadenus leimanthoides & 638184.1900 & 4329251.1300 & G4Q & S2 \\
Zigadenus leimanthoides & 639545.1878 & 4332471.5369 & G4Q & S2 \\
\hline
\end{tabular}

